\title{
Status Report for the Small-Tube Lysimeter Facility Fiscal Year 1992
}

\author{
M. R. Sackschewsky \\ C. J. Kemp \\ Westinghouse Hanford Company \\ L. L. Cadwell \\ Pacific Northwest Laboratory \\ Date Published \\ July 1993
}

Prepared for the U.S. Department of Energy

Office of Environmental Restoration and

Waste Management

\footnotetext{
(2) Westinghouse P.O. Box 1970

Hanford Conpamy Richland, Washington 99352

Hanford Operations and Engineering Contractor for the

U.S. Department of Energy under Contract DE-AC06-87RL10930
}

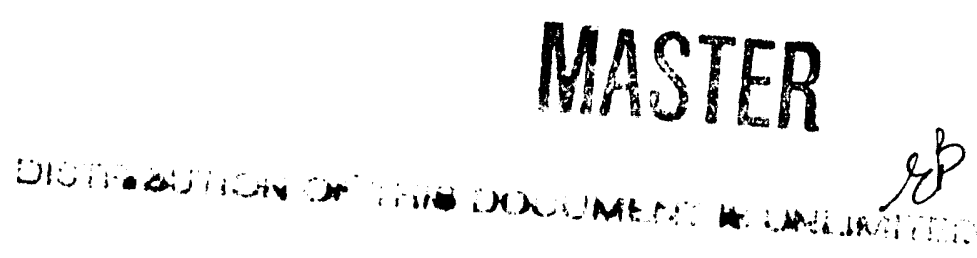




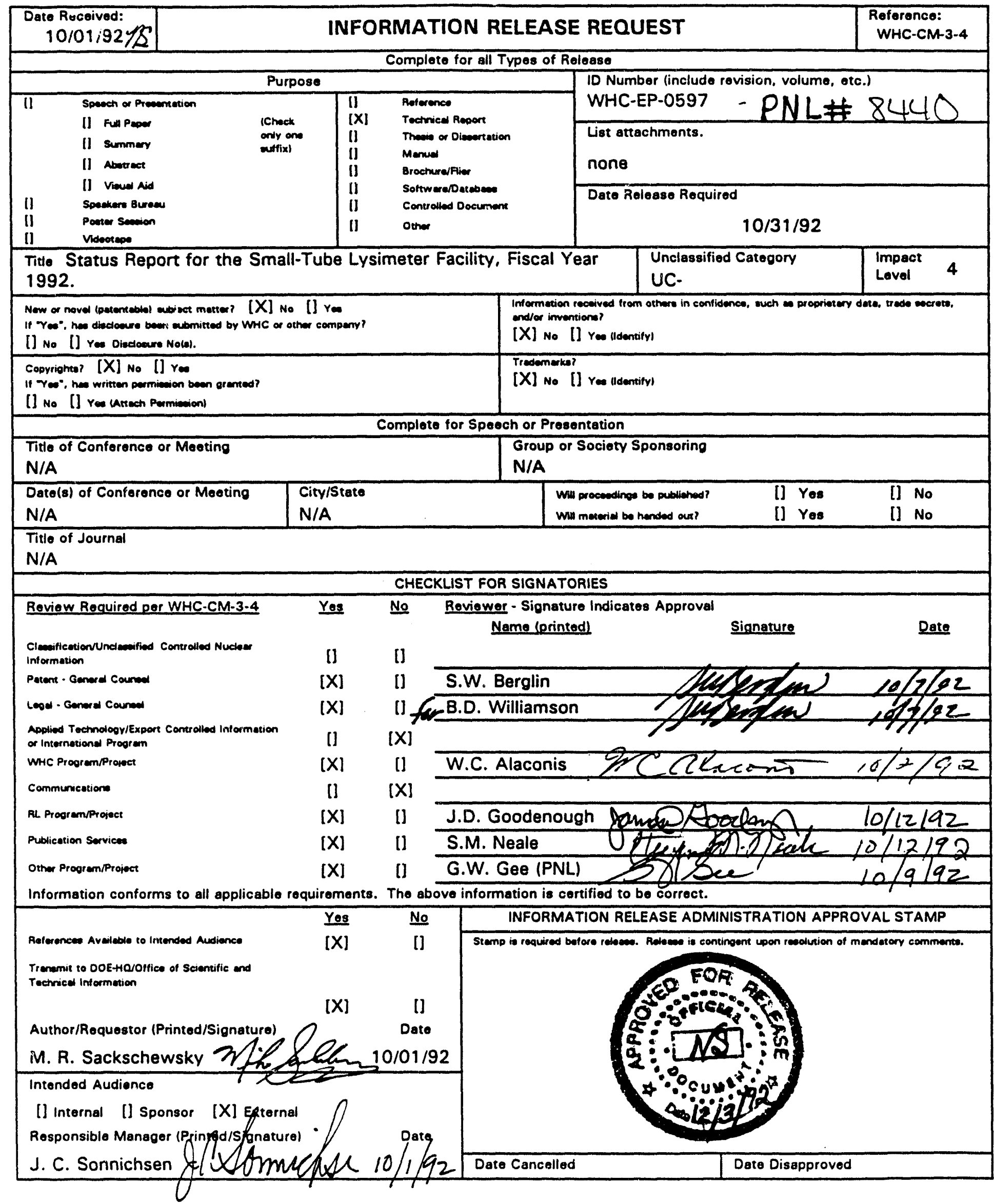




\section{EXECUTIVE SUMMARY}

Westinghouse Hanford Company and Pacific Northwest Laboratory are jointly developing earthen protective barriers for the near-surface disposal of radioactive and hazardous waste at the Hanford Site. The proposed barrier design consists of a blanket of fine-textured soil overlying a sequence of layers, varying from sand to basalt riprap. The experiments conducted at the Small-Tube Lysimeter Facility (STLF) were designed to measure the influence of erosion-control practices and alternate barrier layer configurations on water movement within the barrier, and extraction of water from the barrier.

This report describes the results of data collected during the period from September 1988 through May 1992 at the STLF. Four concurrent experiments are being performed at this facility, each of these experiments are designed to test different components of the proposed barrier. The experiments are as follows.

\section{Surface Treatment Effects (12 treatments with 5 replications)}

This experiment is designed to test the effects of various erosioncontrol practices on soil-column water storage and evapotranspiration, and includes all possible combinations of the following:

- Surface treatment (plain soil, gravel admix, gravel mulch)

- Precipitation (ambient and irrigation to two to three times normal precipitation)

- Vegetation (cheatgrass and bare).

\section{Surface Sand and Gravel Effects (6 Treatments, 5 replications)}

This experiment is designed to assess the effects of aeolian deposition of sand on a protective barrier. The results are compared with the effects of a gravel mulch erosion control treatment. All of these lysimeters receive supplemental irrigation to two to three times average precipitation. Treatments include combinations of the following:

- Surface layer (none, sand, gravel)

- Vegetation (cheatgrass and bare).

\section{Layering Sequence Effects (4 treatments with 5 replications)}

This experiment is designed to test two different subsurface capillary break structures under supplemental irrigation. Treatments include combinations of the following:

- Bimodal or pit-run gravel sublayer versus graded sand

- The presence or absence of vegetation. 


\section{Alternative Barriers ( 3 Treatments with 5 replications)}

Low-permeability subsurface infiltration barriers are being considered a built-in redundancy for protection against water infiltration through the protective barrier. The performance of these alternative barriers is being examined at the STLF. Described in this report are results for clay and chemical grout subsurface barriers. None of the lysimeters is vegetated and all receive supplemental irrigation.

\section{RESULTS}

Surface Treatment Effects: All three of the main factors (surface treatment, precipitation, and vegetation) had significant effects on both water storage change and cumulative evapotranspiration. In general, lysimeters with a gravel mulch surface had significantly greater storage change and significantly less cumulative evapotranspiration than lysimeters with either a soil or gravel admix surface. The presence of vegetation generally increased the evapotranspiration and decreased the amount of storage. Lysimeters that received supplemental irrigation typically had greater evapotranspiration and greater storage than lysimeters that received ambient precipitation. Only the gravel mulch treatments produced detectable quantities of drainage.

Surface Sand and Gravel Effects: A sand deposition layer had a similar effect on soil-column water balance as a gravel mulch layer. Both types of surface layers significantly decreased the amount of evapotranspiration and increased the amount of storage compared to control lysimeters that have a plain soil surface. Vegetation significantly increased the amount of cumulative evapotranspiration and decreased the amount of storage in the sand and gravel covered lysimeters, especially during the summer periods. Drainage was detected from all the sand-covered and gravel-covered lysimeters, with the nonvegetated treatments producing more drainage than the vegetated treatments.

Layering Sequence Effects: There were no significant storage or evapotranspiration differences between the bimodal and graded subsurface layering treatments. Vegetation tended to increase the evapotranspiration and decrease the total storage change only during the drier portions of the year. No drainage was found in any of the bimodal or graded layer lysimeters.

Alternative Barrier Effects: There were generally no significant storage or evapotranspiration differences between the clay and grout treatments. However, the grout treatment appears to have higher amounts of evapotranspiration and lower storage than the clay or bimodal capillary break treatments under three times the supplemental irrigation. The reasons for these differences are not clear. None of the clay or grout lysimeters produced detectable drainage.

All of the barrier configurations (except those with sand or gravel surfaces) with or without plants and with or without gravel admix prevented drainage both under ambient precipitation conditions and precipitation conditions three times the long-term average. These results indicate that the protective barrier, as currently envisioned, will prevent water infiltration 
under the conditions simulated, even under conditions of increased precipitation and lack of vegetative cover as could occur following a fire on the barrier surface. Lysimeters with either a sand or gravel surface produced drainage. This suggests that if either of these conditions occur on a fullscale protective barrier, then infiltration may be possible. 


\section{CONTENTS}

1.0 INTRODUCTION . . . . . . . . . . . . . . . . . . . . . 1-1

2.0 MATERIALS AND METHODS .................... . . . . . .

2.1 THE SMALL-TUBE LYSIMETER FACILITY . . . . . . . . . . . 2-1

2.2 DESCRIPTION OF EXPERIMENTS . . . . . . . . . . . . . . . 2-4

2.2.1 Experiment ................ 2-4

2.2.2 Experiment 2................... 2-7

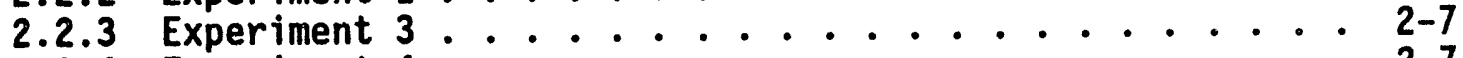

2.2.4 Experiment 4 ................ 2-7

2.3 SUPPLEMENTAL APPLIED IRRIGATION . . . . . . . . . . . 2-7

2.4 LYSIMETER PLANTINGS . . . . . . . . . . . . . . . . . . 2-10

2.5 TEMPERATURE EFFECTS .................... . . 2-10

2.6 Data Analysis ................ 2-11

3.0 WATER BALANCE RESULTS . . . . . . . . . . . . . . . . . . 3-1

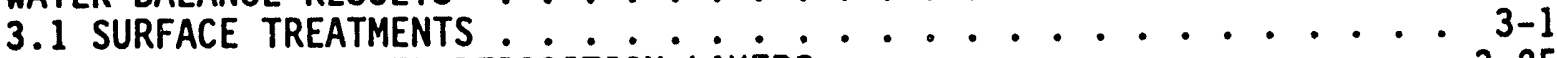

3.2 SAND AND GRAVEL DEPOSITION LAYERS . . . . . . . . . . . 3-25

3.3 CAPILLARY BREAK CONFIGURATION AND IMPERMEABLE LAYERS . . . . 3-35

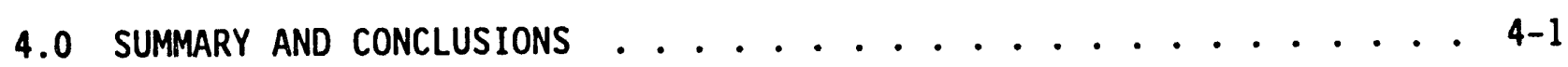

5.0 REFERENCES . . . . . . . . . . . . . . . . . . . 5-1 
WHC-EP-0597

\section{LIST OF FIGURES}

2-1 Smal1-Tube Lysimeter Array Within the Field Lysimeter Complex . . . 2-2

2-2 Treatment Numbers .................. 2-3

2-3 Surface Treatment and Layering Sequence Experiments . . . . . . . 2-8

2-4 Irrigation and Precipitation, September 1988 through $2-9$

September 1992 . . . . . . . . . . . . . . . 2-9

3-1 Surface Treatments Cumulative Storage Change . . . . . . . . 3-2

3-2 Surface Treatments Cumulative Evapotranspiration . . . . . . . 3-3

3-3 Surface Treatments Storage Change Differences, September 1988

to May 1989 . . . . . . . . . . . . . . . . 3-11

3-4 Surface Treatments Total Evapotranspiration Differences,

September 1988 to May 1989 . . . . . . . . . . . . . 3-12

3-5 Surface Treatments Storage Change Differences, September 1988.

3-6 Surface Treatments Total Evapotranspiration Differences,

September 1988 to October 1989 ............... . 3-14

3-7 Surface Treatments Storage Change Differences, September 1988

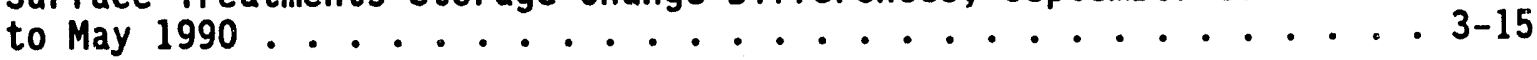

3-8 Surface Treatments Total Evapotranspiration Differences,
September 1988 to May 1990 . . . . . . . . . . . . . . . .

3-9 Surface Treatments Storage Change Differences, September 1988

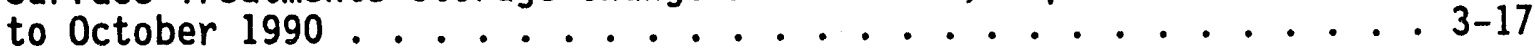

3-10 Surface Treatments Total Evapotranspiration Differences,
September 1988 to October 1990 . . . . . . . . . . . . . .

3-11 Surface Treatments Storage Change Differences, September 1988

to March 1991... . . . . . . . . . . . . . . . 3-19

3-12 Surface Treatments Total Evapotranspiration Differences,

September 1988, to March 1991............... 3-20

3-13 Surface Treatments Storage Change Differences, September 1988

to September 1991 . . . . . . . . . . . . . . 3-21

3-14 Surface Treatments Total Evapotranspiration Differences,

September 1988 to September 1991 . . . . . . . . . . . 3-22

3-15 Surface Treatments Storage Change Differences, September 1988

to March 1992 . . . . . . . . . . . . . . . . 3-23 
WHC-EP-0597

\section{LIST OF FIGURES (contir:ted)}

3-16 Surface Treatments Total Evapotranspiration Differences,

September 1988 to March 1992 . . . . . . . . . . . . . 3-24

3-17 Irrigated Gravel and Sand Treatments Cumulative Drainage . . . 3-26

3-18 Irrigated Gravel and Sand Treatments Cumulative Storage Change . . 3-27

3-19 Irrigated Gravel and Sand Treatments Cumulative Evapotranspiration .............. . . 3-28

3-20 Sand and Gravel Mulches Storage Change Differences . . . . . . 3-33

3-21 Sand and Gravel Mulches Total Evapotranspiration Differences . . 3-34

3-22 Alternative Barrier Types Cumulative Siorage Change . . . . . . 3-36

3-23 Alternative Barrier Types Cumulative Evapotranspiration . . . . . 3-37

3-24 Alternative Barrier Configurations Storage Change Differences . . . 3-45

3-25 Alternative Barrier Configurations Total Evapotranspiration Differences................... 3-46 
WHC-EP-0597

\section{LIST OF TABLES}

2-1 Treatment Combinations ................. 2-5

2-2 Measurement Dates . . . . . . . . . . . . . . . 2-6

3-1 Surface Treatments Analysis of Variance, September 1988 to

May 1989 ....................... 3-4

3-2 Surface Treatments Analysis of Variance, September 1988 to

october 1989 ...................... 3-5

3-3 Surface Treatments Analysis of Variance, September 1988 to

May 1990 ....................... 3-6

3-4 Surface Treatments Analysis of Variance, September 1988 to

October 1990 .................... . . 3-7

3-5 Surface Treatments Analysis of Variance, September 1988 to March 1991 ....................... 3-8

3-6 Surface Treatments Analysis of Variance, September 1988 to

September 1391 . . . . . . . . . . . . . . . 3-9

3-7 Surface Treatments Analysis of Variance, September 1988 to

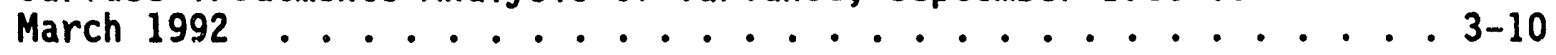

3-8 Sand and Gravel Mulches Analysis of Variance, September 1988

to May 1989 . . . . . . . . . . . . . . . . . . . . 3-29

3-9 Sand and Gravel Mulches Analysis of Variance, September 1988

to October 1989 . . . . . . . . . . . . . . . . 3-29

3-10 Sand and Gravel Mulches Analysis of Variance, September 1988

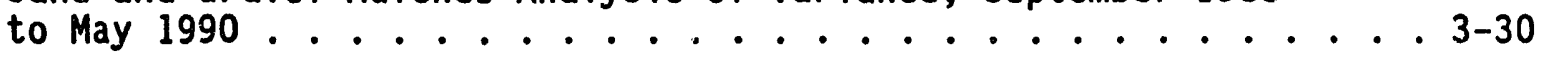

3-11 Sand and Gravel Mulches Analysis of Variance, September 1988

to October 1990 ................ . . . 3-30

3-12 Sand and Gravel Mulches Analysis of Variance, September 1988 to March 1991 ... . . . . . . . . . . . . . . . 3-31

3-13 Sand and Gravel Mulches Analysis of Variance, September 1988 to September 1991 .................... 3-31

3-14 Sand and Gravel Mulches Analysis of Variance, September 1988 to March 1992 ...................... 3-32

3-15 Capillary Break Configuration Analysis of Variance, September 1988 to May 1989

3-16 Capillary Break Configuration Analysis of Variance,

September 1988 to October 1989 3-38 


\section{LIST OF TABLES (continued)}

3-17 Capillary Break Configuration Analysis of Variance, September 1988 to May 1990 . . . . . . . . . . . . 3-39

3-18 Capillary Break Configuration Analysis of Variance, September 1988 to October 1990 . . . . . . . . . . . 3-39

3-19 Capillary Break Configuration Analysis of Variance, September 1988 to March 1991 . . . . . . . . . . . . . 3-40

3-20 Capillary Break Configuration Analysis of Variance, September 1988 to September 1991 . . . . . . . . . . . 3-40

3-21 Capillary Break Configuration Analysis of Variance, September 1988 to March 1992 . . . . . . . . . . . . . . 3-41

3-22 Alternative/Impermeable Barriers Analysis of Variance, September 1988 to May 1989 ................ 3-41

3-23 Alternative/Impermeable Barriers Analysis of Variance, September 1988 to October 1989 ............. 3-42

3-24 Alternative/Impermeable Barriers Analys is of Variance, September 1988 to May 1990 . . . . . . . . . . . . 3-42

3-25 Alternative/Impermeable Barriers Analys is of Variance, September 1988 to October 1990 ............. 3-43

3-26 Alternative/Impermeable Barriers Analysis of Variance, September 1988 to March 1991 . . . . . . . . . . . . 3-43

3-27 Alternative/Impermeable Barriers Analysis of Variance, September 1988 to September 1991 . . . . . . . . . . 3-44

3-28 Alternative/Impermeable Barriers Analysis of Variance, September 1988 to March 1992 3-44 
WHC-EP-0597

\section{ACRONYMS}

ABS

ALE

FLTF

FY

HMS

PNL

PVS

STLF

Westinghouse

Hanford

acrylanitrile butadiene styrene

arid 1 and ecology

Field Lysimeter Test Facility

fiscal year

Hanford Meteorological Station

Pacific Northwest Laboratory

polyvinyl chloride

Smal1-Tube Lysimeter Facility

Westinghouse Hanford Company 
WHC-EP-0597

This page intentionally left blank. 


\subsection{INTRODUCTION}

The Westinghouse Hanford Company (Westinghouse Hanford) and Pacific Northwest Laboratory (PNL) are jointly developing protective barriers for the long-term isolation of low-level radioactive and mixed radioactive and hazardous waste at the U.S. Department of Energy's Hanford Site. Protective barriers have been identified as an integral part of the overall final disposal strategy for low-level defense waste at the Hanford Site (DOE 1987).

Several performance objectives have been developed for a protective barrier: (1) water infiltration to and through the waste should be limited to near-zero amounts, (2) intrusion into the waste by plants, animals, and humans should be minimized, (3) minimal wind and/or water erosion should occur during the functional lifetime of the barrier, and (4) the barrier should be maintenance free and functional for a period of at ieast 1,000 years. A protective barrier designed to meet these general criteria should isolate the waste, should minimize the transport and release of contaminants to the environment, and could be considerably less expensive than other treatment and disposal options (DOE 1987).

The current conceptual design of the Hanford Site protective barrier is a multilayered earthen structure consisting of a fine soil surface layer overlying a sequence of layers grading downward from sand to basalt riprap. The textural difference between the fine soil and courser materials functions as a capillary break that helps prevent water from flowing from the finer material to the courser material. This allows the fine soil layer to hold more moisture than if this capiliary break were not present. Water held above the textural interface can then be recycled back to the atmosphere through the processes of evaporation and plant transpiration. Additional, redundant infiltration barriers of clay, chemical grout, or asphalt may also be included in the design. The basalt riprap layer is designed to reduce plant-root and animal intrusion into the waste, and may also serve as a deterrent to human intrusion. Erosion control will be accomplished through the placement of gravel on the surface of the fine soil surface either as a mulch, or as an "admixture" (homogeneous mixture of gravel and soil) in the upper soil layers, establishment of a vegetative cover, and control of the barrier surface slope angle. Preliminary wind tunnel investigations indicate that both methods provide adequate protection from wind erosion (Ligotke 1989, Ligotke and Kopfer 1990). The conceptual protective barrier utilizes only "natural" materials that are expected to withstand degradation for at least 1,000 years.

The Small-Tube Lysimeter Facility (STLF) was designed and constructed to test the effects of different layering sequences, surface erosion control practices, and alternative infiltration barriers on the soil column water balance of a simulated protective barrier (Waugh and Link 1987, Relyea et al. 1990, Freeman et al. 1989). The conceptual barrier utilizes a carefully graded series of gravel, sand, and fine soil to form a stable capillary break. An alternative structure of the capillary break is fine soil over a "bimodal" mixture of gravel and sand. The latter would probably be less expensive to construct and would more closely resemble natural soil structures on the Hanford Site. However, because the bimodal design may be less effective in the minimization of infiltration, this is currently being tested at the STLF. 
The addition of gravel to the barrier surface either as a mulch or as an admix will provide considerable erosion protection compared with a bare soil surface. The surface gravel also may affect infiltration and decrease the amount of soil evaporation, thus increasing the likelihood of water infiltration through the waste. These effects are being examined at the STLF and at the Admix Gravel Test Plots (Waugh and Link 1987, Waugh 1989). An additional potential problem for a protective barrier is the eolian deposition of sand on top of the fine soil layer. This also would be expected to increase the soil permeability and reduce the amount of evaporation. This effect is also being examined at the STLF.

The inclusion of a very low-permeability sublayer within the protective barrier would function as a redundant infiltration barrier and wocild help to protect the underlying waste even during extremely high-intensity storm events. The efficacy of sublayers of clay, chemical grout, and various types of asphalt are being studied at the STLF. Studies involving clay and chemical grout sublayers are described in this report; the asphalt experiments are described separately (Freeman et al. 1989, Freeman and Gee 1989).

This report describes the operations and results of nearly 4 years of data collection at the STLF. Relyea et al. (1990) describe the initial conditions and fill specifications for each of the lysimeters. Sackschewsky et al. (1991) described the results collected over the first 2 years of monitoring. This report discusses the monitoring results collected from fiscal year (FY) 1989 through FY 1992. 
WHC-EP-0597

\subsection{MATERIALS AND METHODS}

\subsection{THE SMALL-TUBE LYSIMETER FACILITY}

The STLF is located adjacent to the Hanford Meteorological Station (HMS), within the protective Barrier Field Lysimeter Complex. It consists of 105 lysimeters arranged in an array of 21 rows of 5 lysimeters each (Figure 2-1). Eighty of the lysimeters (rows 1 through 16) are used to test the effects of various erosion control practices, sand deposition, and barrier layering sequences on soil column water balance. The remaining 25 lysimeters (rows 17 through 21) are used to test alternative infiltration barriers (clay, chemical grout, asphalt) that have been proposed as "impermeable" components of a protective barrier system (Freeman et a1. 1989).

Each lysimeter consists of a 169-cm-1ong, 30.4-cm-ID acrylonitrilebutadiene-styrene (ABS) well casing placed inside a $175-\mathrm{cm}-1$ ong, $39-\mathrm{cm}-\mathrm{dm}$ polyvinyl-chloride (PVC) sleeve. The tops of the sleeves and lysimeter tubes are placed approximately $2.5 \mathrm{~cm}$ above grade. A rubber insulating collar (36-cm bicycle inner tube, painted white) is placed at the upper end of each lysimeter tube to minimize heat transfer between the atmosphere and the airspace between the sleeve and lysimeter tube. Each lysimeter tube is fitted with a recessed cap at the bottom and an aluminum lifting collar at the top. The aluminum collar serves both as a rigging attachment point during weighing and as a coupling interface for an acrylic plant-gas exchaige chamber used for separate controlled experiments on photosynthesis and evapotranspiration (ET) (Waugh and Link 1987, Link and Waugh 1989, Link ot al. 1990).

The sealed tube serves as a combined weighing and drainage lysimeter. Drainage is measured monthly by collecting water from a clear, flexible polymer tube that is fitted to a threaded drain hole at the low end of the end cap. Changes in water storage are estimated as the monthly weight change measured by suspending the lysimeters from a load cell attached to a gantry crane.

The lysimeters were each filled by hand with layers of gravel, sand, silt loam soil, "pit-run" gravel, and impermeable barrier material. The exact materials and layering sequences for each tube depended on the assigned treatment combination for that lysimeter (Figure 2-2). The treatment combinations are described in Section 2.2, and complete descriptions of the lift thicknesses, weights, moisture contents, and initial conditions for each lysimeter can be found in Relyea et al. (1990). Construction and filling were completed in mid-September 1988 . A section of black steel grating ( 1 by $2 \mathrm{~m}$ ) is placed at the soil surface between the rows of lysimeters. These grating sections allow workers to move about the facility with minimal disturbance to the lysimeters. 
Figure 2-1. Smal1-Tube Lysimeter Array Within the Field Lysimeter Complex.

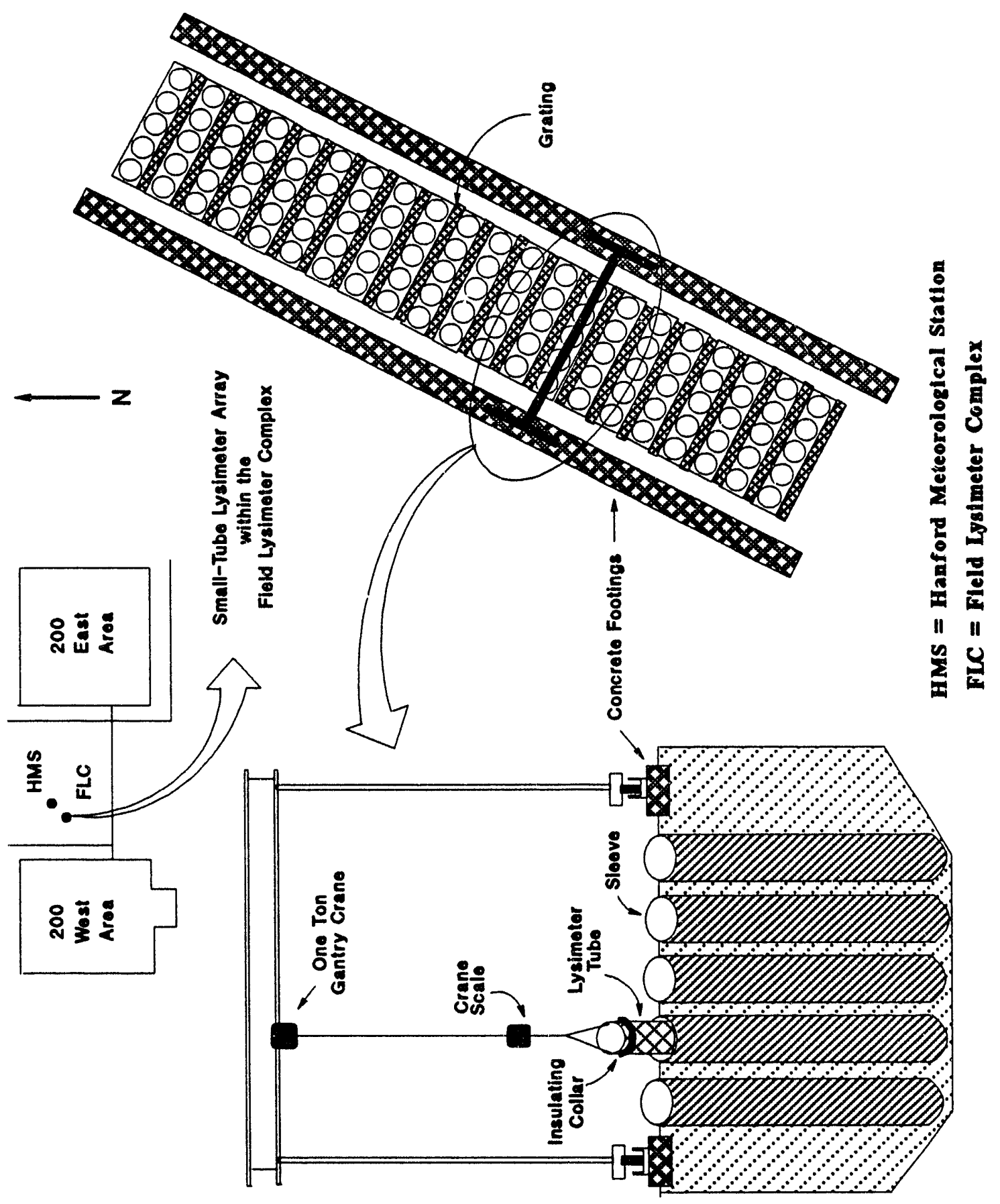


WHC-EP-0597

Figure 2-2. Treatment Numbers.

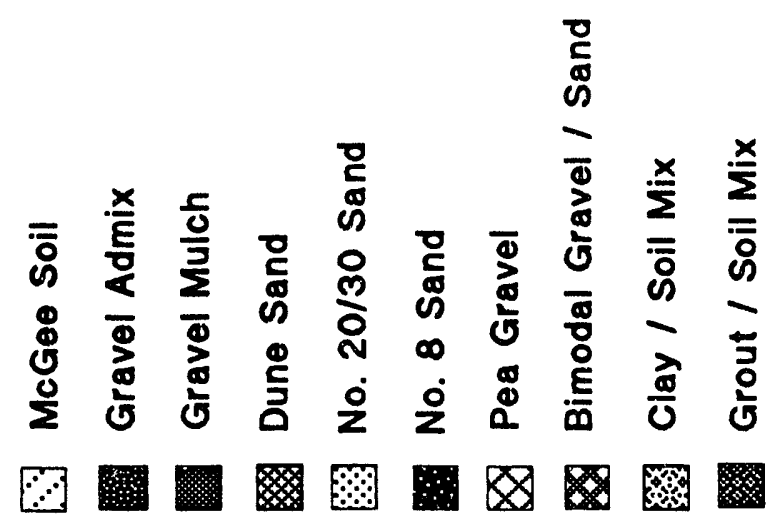
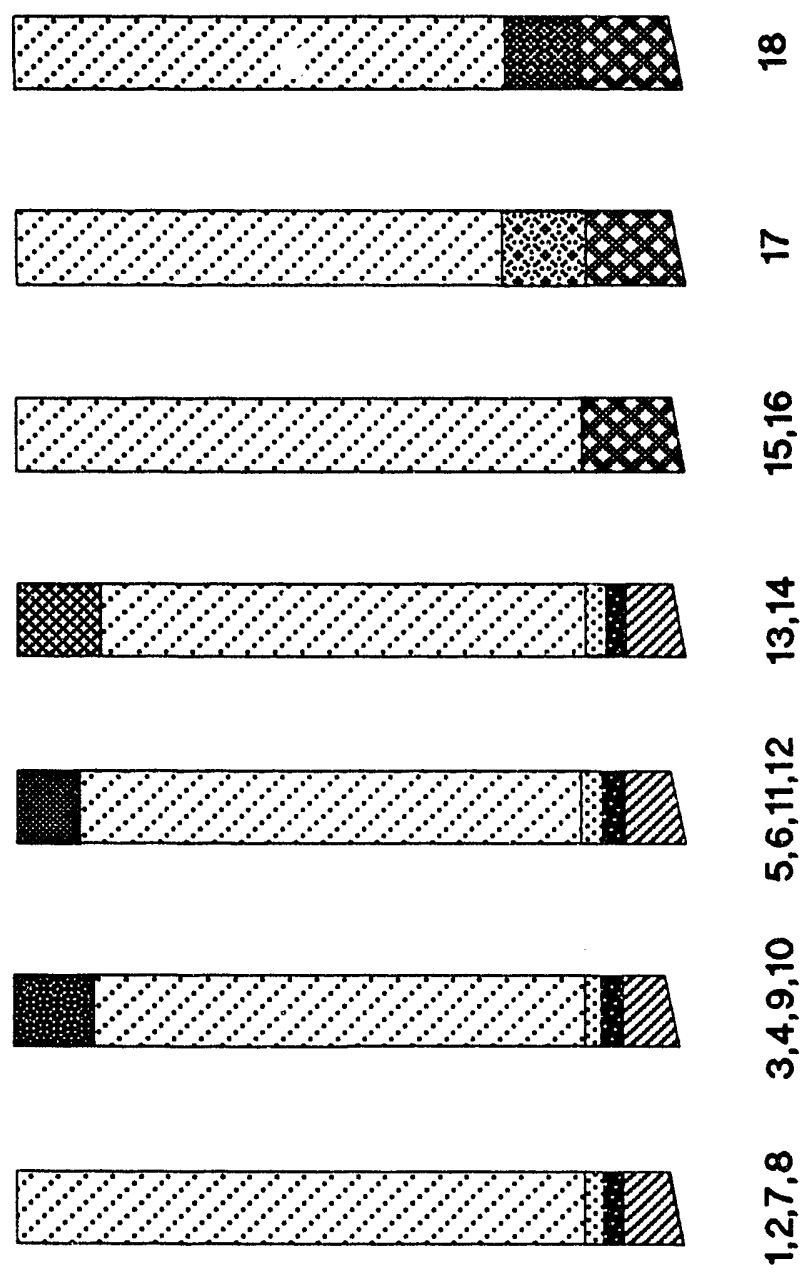

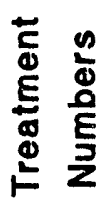


WHC-EP-0597

\subsection{DESCRIPTION OF EXPERIMENTS}

The experiments at STLF represent an expansion of the studies conducted at the Field Lysimeter Test Facility (FLTF) (Kirkham et al. 1987). Several of the treatment combinations are in common with the treatments included in the FLTF design, and some match the conditions in previous UNSAT-H simulations of unsaturated soll water movement (Fayer et a1. 1985) performed in support of the Hanford Site protective barrier program. The data acquired at STLF will supplement the FLTF data for validation of the UNSAT-H computer code (Fayer 1990). The primary advantage of performing experiments at STLF is the ability to increase greatly both the number of treatment combinations and the number of replicates of each treatment, thus improving the statistical power and confidence levels associated with the analysis of the resultant data (Waugh and Link 1987).

The studies conducted at STLF are primarily comparative experiments devised to measure the influence on water storage, evapotranspiration, and drainage of the following factors:

- Surface gravel admix and gravel mulch

- Sand deposition

- 2 to 3 time the long-term average precipitation

- Vegetation

- Structural sequence of the capillary break

- "Impermeable" alternative infiltration barriers.

One or more of these factors are included in the treatment combination assigned to each lysimeter. These treatment combinations are summarized in Table 2-1. Treatment descriptions and initial results of the asphalt barrier tests are provided in Freeman et al. (1989) and Freeman and Gee (1989).

The inclusion of all six of the factors, listed previously, in one experimental design would require a facility at least twice as large as the present STLF and would result in several impractical treatment combinations. Therefore, four interconnected but separate experiments (statistical models) are performed simultaneously to analyze the effects of the six factors of interest. A complete statistical description of these models is provided in Relyea et al. (1990). The experimental designs are briefly summarized here.

\subsubsection{Experiment}

The first experiment is a $3 \times 2 \times 2$ factorial analysis of variance designed to test the effects of erosion-control practices. It includes three different surface treatments ( $p l a i n$ soil, 30 percent gravel admix, and surface gravel mulch), two levels of precipitation (ambient and supplemental irrigation), and the presence or absence of vegetation. There are a total of 12 treatment combinations (treatments 1 through 12), with 5 replicates of each combination. All of the lysimeters in this experiment have a "graded" capillary break Structure. 


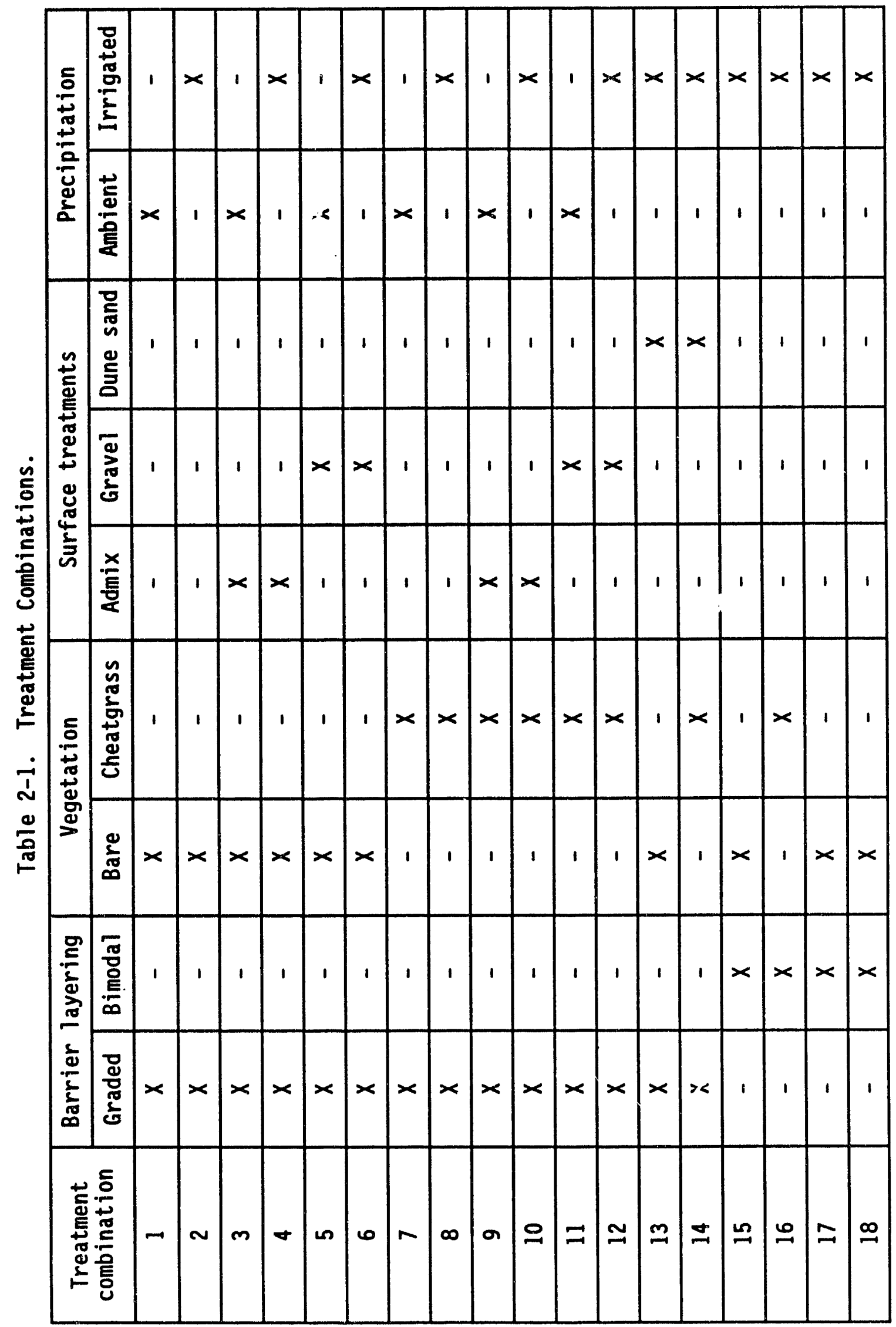


Table 2-2. Measurement Dates.

\begin{tabular}{|c|c|c|c|c|c|}
\hline $\begin{array}{l}\text { Measurement } \\
\text { period }\end{array}$ & Date & $\begin{array}{c}\text { Days since } \\
9 / 1 / 88\end{array}$ & $\begin{array}{l}\text { Measurement } \\
\text { period }\end{array}$ & Date & $\begin{array}{c}\text { Days since } \\
9 / 1 / 88\end{array}$ \\
\hline 1 & 16-Dec-88 & 106 & $17^{\star}$ & 03-May-90 & 609 \\
\hline 2 & 23-Jan-89 & 144 & 18 & 05-Jun-90 & 642 \\
\hline 3 & 13-Mar-89 & 193 & 19 & 02-Ju1-90 & 669 \\
\hline 4 & 06-Apr-89 & 217 & 20 & 08-Aug-90 & 706 \\
\hline 5 & 01-May-89 & 242 & 21 & $13-$ Sep-90 & 742 \\
\hline 6 & $01-J u n-89$ & 273 & $22^{\star}$ & $01-0 c t-90$ & 760 \\
\hline 7 & 29-Jun-89 & 301 & 23 & 15-Nov-90 & 805 \\
\hline 8 & 02-Aug-89 & 335 & 24 & 08-Jan-91 & 859 \\
\hline 9 & 01-Sep-89 & 365 & 25 & 14-Feb-91 & 896 \\
\hline $10^{*}$ & $02-0 c t-89$ & 396 & $26^{*}$ & 20-Mar-91 & 930 \\
\hline 11 & 01-Nov-89 & 426 & 27 & 26-Apr-91 & 967 \\
\hline 12 & 05-Dec-89 & 460 & 28 & $30-J u 1-91$ & 1,062 \\
\hline 13 & 03-Jan-90 & 489 & $29^{\prime \prime}$ & $12-$ Sep-91 & 1,106 \\
\hline 14 & $31-J a n-90$ & 517 & 30 & 04-Nov-91 & 1,159 \\
\hline 15 & 05-Mar-90 & 550 & 31 & 17-Mar-92 & 1,293 \\
\hline 16 & $02-A p r-90$ & 578 & $32^{*}$ & 06-May-92 & 1,343 \\
\hline
\end{tabular}

"Indicates dates used in statistical analyses. 


\subsubsection{Experiment 2}

This experiment is a $2 \times 2$ factorial analysis of variance designed to test the effects of different capillary break layering sequences. It includes two different capillary break structures ("graded" sand versus the bimodal or soil over pitrun gravel/sand structure) and the presence and absence of vegetation. This experiment includes four treatment combinations (treatments $2,8,15$, and 16) with five replicates of each treatment.

\subsubsection{Experiment 3}

The third experiment is a $2 \times 2$ factorial analysis of variance designed to test the effects of a sand deposition layer and vegetation on soil column water balance. It includes 2 sand deposition treatments (surface sand layer and $20-\mathrm{cm}$ surface sand 1 ayer) and 2 levels of vegetation (vegetation and cheatgrass). This experiment includes treatment combinations $2,8,13$, and 14, with five replicates of each treatment combination. Each of these lysimeters has the "graded sand" capillary break. All of the lysimeters in experiments 2 and 3 receive the supplemental irrigation treatment.

\subsubsection{Experiment 4}

The fourth experiment uses a one-way analysis of variance to compare the effects of a clay subsurface layer (treatment 17), a chemical grout layer (treatment 18), and the designated control treatment (bimodal capillary break--treatment 15), using five replicates of each treatment. An additional control treatment (graded subsurface capillary break) in some of the analysis was included. All of the lysimeters in this experiment receive the supplemental irrigation treatment and none are vegetated.

The 80 lysimeters used in experiments one through three are arranged randomly throughout rows 1 through 16 of the STLF array (Figure 2-3). The five lysimeters used for testing the clay layer are in row 17, and the five used for chemical grout are in row 18. Rows 19 through 21 are used for a separate evaluation of asphalt subsurface layers (Freeman et al. 1989) and are not included in the main statistical design.

\subsection{SUPPLEMENTAL APPLIED IRRIGATION}

Two precipitation treatments are included in the STLF experiments. The ambient treatment lysimeters receive only natural precipitation, the amount of which is recorded at the HMS. The supplemental irrigation treatment receives natural precipitation plus enough irrigation to bring the total water input to a predetermined total. For the first 2 years of the experiments the amount added increased the total water input to twice the long-term monthly average. Since November 1990 this has been increased to three times the long-term bimonthly average. Irrigation was applied monthly during the first 2 years and bimonthly during the second 2 years. Irrigation is applied during a period of 1 to 4 hours within 2 to 3 weeks following the end of each month for which rainfall is less than twice the long-term average. Figure 2-4 shows the monthly average precipitation, the recorded precipitation and the amounts of 
Figure 2-3. Surface Treatment and Layering Sequence Experiments.

\section{Surface \\ Treatment \\ and \\ Layering \\ Sequence \\ Experiments}

\section{Alternate \\ Barrier}

Experiments

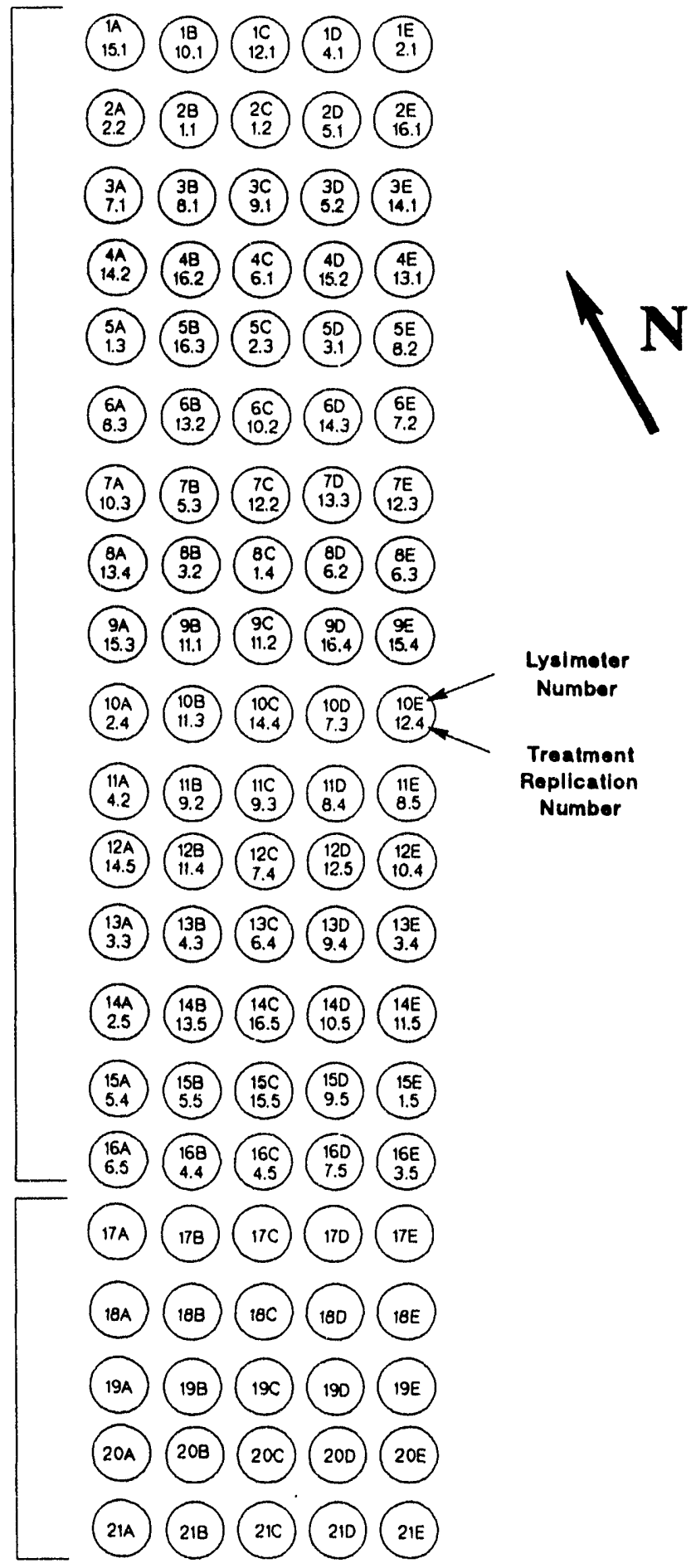


WHC-EP-0597

Figure 2-4. Irrigation and Precipitation, September 1988 through September 1992.

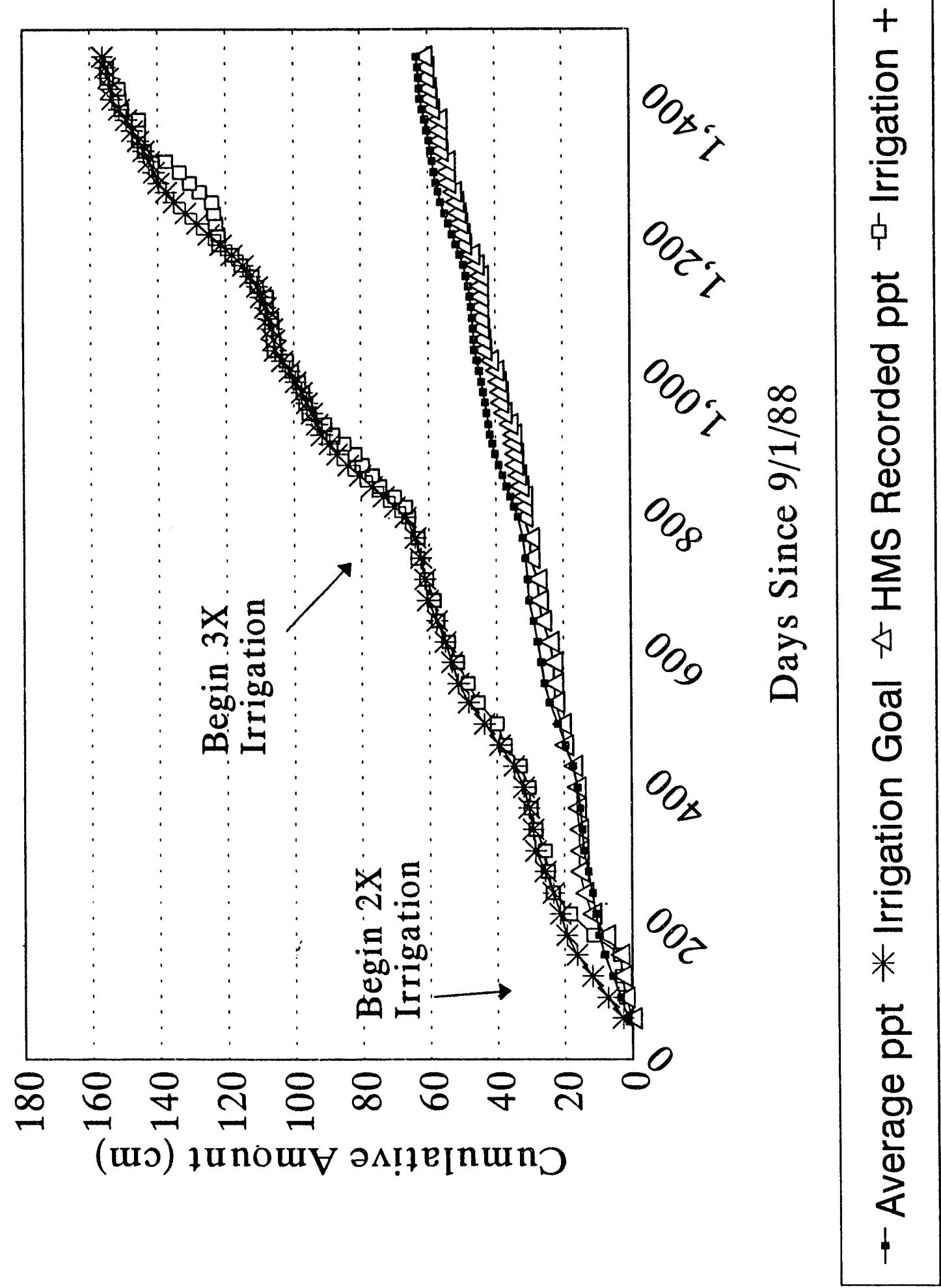


irrigation applied during each month of the study. In April 1989 some of the ambient tubes were inadvertently irrigated; the same amount of water $(2.49 \mathrm{~cm})$ was subsequently added to all of the ambient tubes to preserve the statistical models described previously.

\subsection{LYSIMETER PLANTINGS}

The 40 lysimeters receiving a vegetated surface treatment (treatments 7 through 12, 14, and 16) were seeded with cheatgrass (Bromus tectorum) in early October, 1989. The seed used was collected from the Hanford Arid Lands Ecology (ALE) Reserve during early June 1989. Seeds were hand stripped from plants selected to be as free of smut as possible. The seeds were air dried and maintained at room temperature in paper bags until planting. Before planting, the seeds were divided into 40 aliquots of approximately 1,000 seeds each, and each aliquot was individually bagged. Just before planting, cheatgrass litter was obtained from the ALE reserve to serve as mulch.

The following planting procedures were used. On the lysimeters with a surtace of plain soil or gravel admix, the soil crust was broken, the seeds contained in one bag were distributed evenly over the disturbed soil, and the seeds then were packed lightly by hand and inulched with approximately $1 \mathrm{~cm}$ of cheatgrass litter. On lysimeters with sand surfaces, the sand was lightly disturbed, then the same procedure was followed. Lysimeters with gravel mulch on the surface were not disturbed before planting. At planting, ambient soil moisture was generally low, because the normal autumn rains had not yet begun. In the surrounding environment, cheatgrass had not yet begun to germinate.

The lysimeters were replanted with cheatgrass in 0ctober 1990 . The same procedures were used as in 1989, with the addition of $0.53 \mathrm{~g}$ ammonium nitrate per lysimeter (equivalent to $25 \mathrm{Kg} \mathrm{N} / \mathrm{Ha}$ ).

Although no plant biomass data have been collected, visual observation indicated that the amount of plant material on the lysimeters during FY 1990 was significantly less than the surrounding shrub areas. The amount of plant biomass significantly increased during FY 1991 and during FY 1992, even though no additional seed was provided during FY 1992.

Planned changes for FY 1993 include the introduction of perennial bunchgrasses (probably Siberian wheatgrass, Agropyron sibericum) to the lysimeters. This will allow for comparisons of the relative effects of annual and perennial grasses on the soil column water balance.

\subsection{TEMPERATURE EFFECTS}

Questions concerning thermal gradients in and around the lysimeters were addressed during FY 1990. Two basic issues were addressed: (1) the possibility of uneven surface temperatures caused by the presence of the black steel grating placed between the lysimeter rows, and (2) vertical gradients within the annulus between the lysimeter tubes and the sleeves that may create temperature profiles that are not reflective of the "natural" soil profiles. 
Hand-held radiometer measurements of surface temperatures indicated that the presence of the black steel grating does not significantly effect the surface temperatures of the lysimeters (Sackschewsky et a1. 1991).

Several insulation methods were considered but rejected because of the concern that the insulation would absorb water and thereby influence lysimeter weights, making it impossible to determine soil water balance parameters accurately by weight change alone. Even a closed-cell foam was found to absorb considerable amounts of water. Bicycle inner tubes of the proper diameter were availabie to fit snugly over the lysimeters and, when inflated, the inner tubes would fill the interspace between the lysimeter and the sleeve. Initial trials indicated the inner tubes are easily installed and removed, are flexible, and perform as an inflatable rubber gasket without absorbing water. The trials also indicated that the inner-tube gaskets provide adequate insulation for the lysimeters (Sackschewsky et al. 1991). All of the lysimeters were fitted with the inner-tube collars in April 1990. The primary problem associated with these collars is the relatively short life-span of the inner tubes under field conditions. Improvements to the system are currently being explored.

\subsection{Data Analysis}

Reported here are the overall trends observed in water storage and ET under the different treatment combinations during the period from September 1988 through May 1992. Additionally, more rigorous statistical analyses are provided for the storage change and cunnulative ET observed at seven selected measurement dates (May 1989, October 1989, May 1990, October 1990, March 1991, September 1991, and March 1992). These dates were selected to correspond to the yearly minima and maxima in storage change. Dates in September or October correspond to the seasonal minima in lysimeter water storage, while those in the spring correspond to the seasonal maxima. In general, the treatment differences present at these selected dates are representative of the other 25 measurement dates. A list of all of the measurement dates, and the corresponding number of days into the experiment for each measurement date is provided in Table 2-2. Treatment differences at the selected sampling dates were compared using Duncan's multiple range test (Snedecor and Cochran 1980), and differences are considered statistically significant at $p \leq 0.05$. 
WHC-EP-0597

This page intentionally left blank.

$2-12$ 
WHC-EP-0597

\subsection{WATER BALANCE RESULTS}

\subsection{SURFACE TREATMENTS}

The long-term patterns of mean lysimeter water storage change is presented in Figure 3-1. The companion pattern for cumulative evapotranspiration is presented in Figure 3-2. In general, greater amounts of water storage and less ET are found in the gravel mulch lysimeters than in either the gravel admix or plain soil surface lysimeters. Irrigation tends to increase both water storage and ET. Vegetation tends to decrease storage and increase ET. The plain soil and gravel admix treatments are very similar in terms of both storage and ET patterns. The patterns for the vegetated treatments are almost identical, while in the nonvegetated treatment the admix lysimeters have a slightly greater amount of storage $(2$ to $4 \mathrm{~cm})$ and slightly lower ET; these differences are never significant. The pair of treatments that does not seem to follow the general patterns are the two gravei mulch, nonirrigated treatments; with vegetation both ET and storage are very similar to the plain soil and admix treatments. In the absence of vegetation, there has been a steady increase in storage such that the nonirrigated lysimeters are becoming similar to the irrigated lysimeters.

The results of the statistical analyses of storage change and ET for the seven selected sampling dates are presented in Tables 3-1 through 3-7, Figures 3-1 through 3-16 show the treatment means and indicate significant treatment differences. Bars labeled with different letters, with in a sampling date, indicate that the treatment differences are significantly different at p $\leq 0.05$.

The main effects of surface type, irrigation treatment, and vegetation were always highly significant for both storage and ET. The significant effect of surface treatment is primarily because the gravei mulch surfaces have significantly lower ET and greater storage than the other two surface treatments. Irrigation increases both storage and ET relative to the nonirrigated treatment, the differences in ET were usually greater than the differences in storage. Vegetation had a significant effect on both ET and storage at all analysis dates except the first (May 1989). There was very little-vegetation present at that measurement date. In general, the presence of vegetation increased ET and decreased storage.

The only interaction effect that was consistently significant is the surface-type $x$ irrigation interaction. This is mainly because of the much larger increase in storage associated with irrigation in the gravel mulch treatments compared to the plain soil or gravel admix treatments. Each of the other interaction effects (Surface $x$ Vegetation, Irrigation $x$ Vegetation, and Surface $x$ Vegetation $x$ Irrigation) were occasionally significant. These occurrences are probably primarily caused by the large differences between the vegetated and nonvegetated, nonirrigated, gravel mulch treatments, and/or by the effects of vegetation on the soil and admix lysinieters in the sumrier of 1991. The data indicate that irrigation allowed the vegetation on these lysimeters to grow to the point where the plants anded up extracting a much greater amount of water from the irrigated lysimeters than in the nonirrigated lysimeters, resulting in lower storage values in the irrigated lysimeters than in the nonirrigated iysimeters, which is the opposite of the normal pattern. 
Figure 3-1. Surface Treatments Cumulative Storage Change.

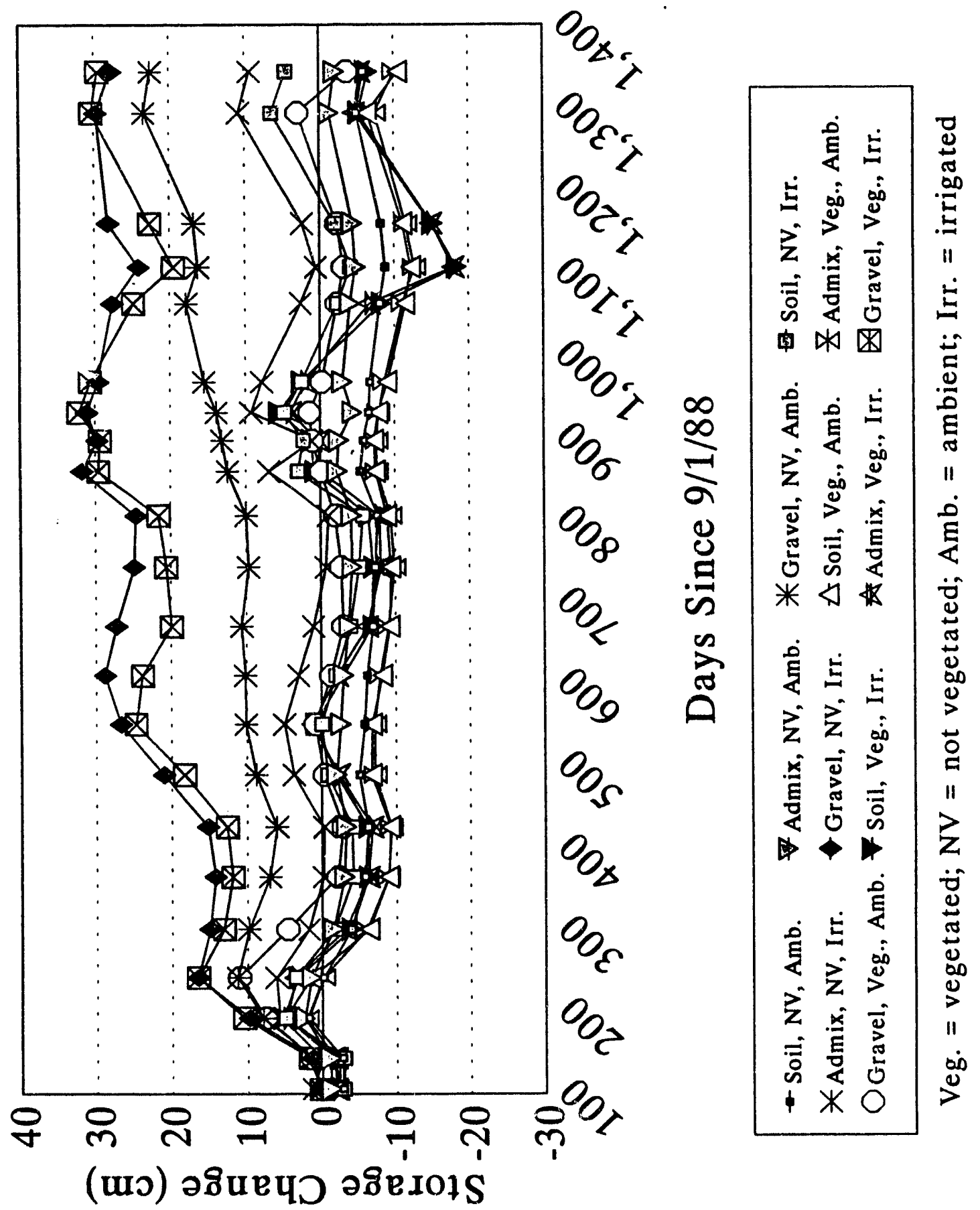


Figure 3-2. Surface Treatments Cumulative Evapotranspiration.

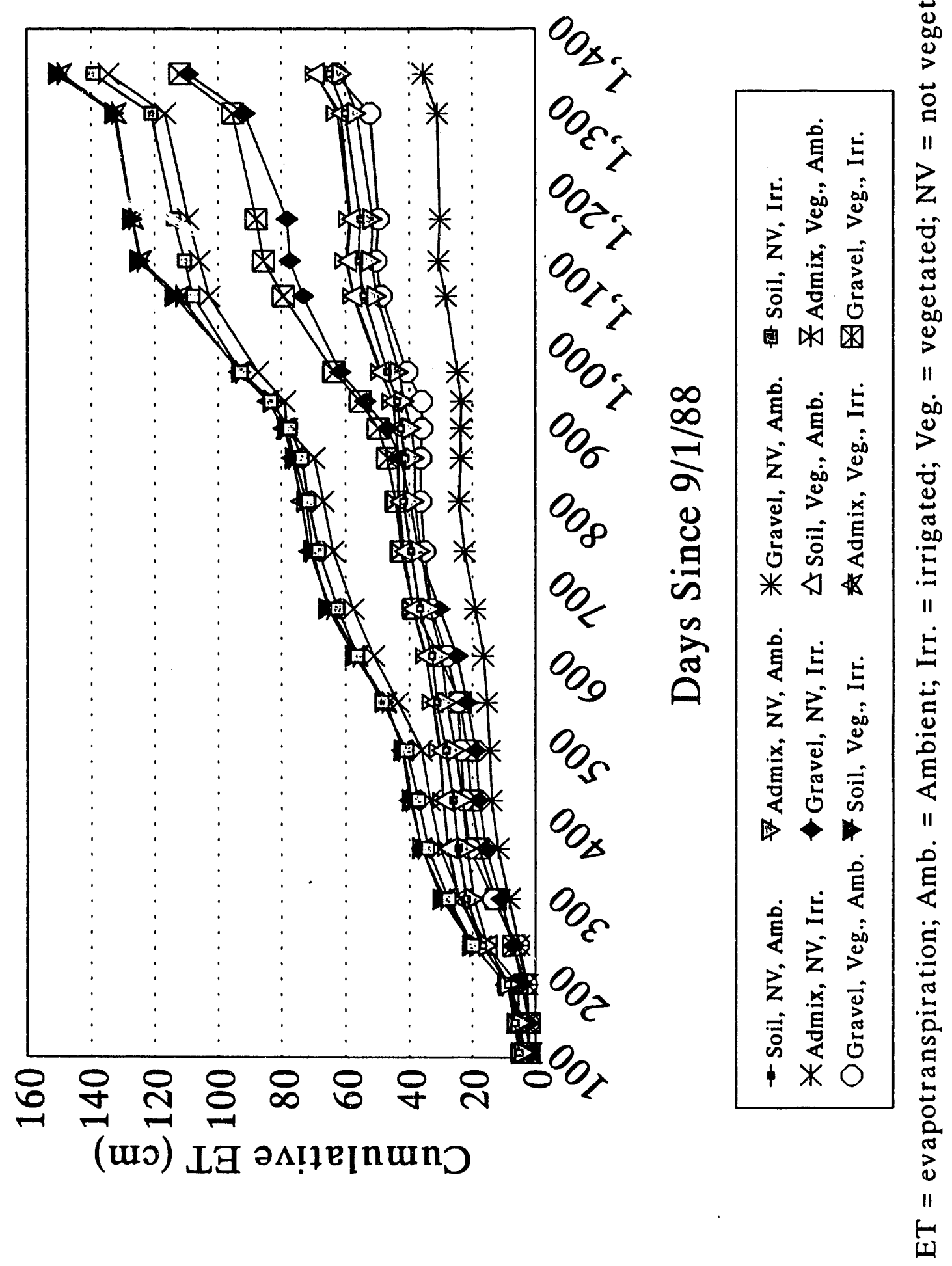


Table 3-1. Surface Treatments Analysis of Variance, September 1988 to May 1989.

\begin{tabular}{|c|c|c|c|c|c|}
\hline \multicolumn{6}{|c|}{ CUMULATIVE STORAGE CHANGE } \\
\hline Source & DF & $\begin{array}{l}\text { Sum of } \\
\text { squares }\end{array}$ & Mean square & $F$ & $P$ \\
\hline Surface & 2 & $1,753.08$ & 876.54 & 119.26 & 0.000 \\
\hline Vegetation & 1 & 3.98 & 3.98 & 0.54 & 0.456 \\
\hline Irrigation & 1 & 260.04 & 260.04 & 35.38 & 0.000 \\
\hline $\begin{array}{l}\text { Surface } x \\
\text { vegetation }\end{array}$ & 2 & 19.22 & 9.61 & 1.31 & 0.280 \\
\hline $\begin{array}{l}\text { Surface } x \\
\text { irrigation }\end{array}$ & 2 & 16.80 & 8.40 & 1.14 & 30.327 \\
\hline $\begin{array}{l}\text { Vegetation } x \\
\text { irrigation }\end{array}$ & 1 & 2.87 & 2.87 & 0.39 & 0.535 \\
\hline $\begin{array}{l}\text { Surface } x \\
\text { vegetation } x \\
\text { irrigation } \\
\end{array}$ & 2 & 3.04 & 1.519 & 0.21 & 0.814 \\
\hline Error & 48 & 352.79 & 7.35 & & \\
\hline \multicolumn{6}{|c|}{ CUMULATIVE EVAPOTRANSPIRATION } \\
\hline Source & DF & $\begin{array}{l}\text { Sum of } \\
\text { squares }\end{array}$ & Mean square & $\mathbf{F}$ & $\mathbf{P}$ \\
\hline Surface & 2 & $1,751.23$ & 875.62 & 119.65 & 0.000 \\
\hline Vegetation & 1 & 4.17 & 4.17 & 0.57 & 0.454 \\
\hline Irrigation & 1 & 114.11 & 114.11 & 15.59 & 0.000 \\
\hline $\begin{array}{c}\text { Surface } x \\
\text { vegetation }\end{array}$ & 2 & 18.77 & 9.38 & 1.28 & 0.287 \\
\hline $\begin{array}{l}\text { Surface } x \\
\text { irrigation }\end{array}$ & 2 & 18.77 & 9.38 & 1.28 & 0.287 \\
\hline \begin{tabular}{|c|} 
Vegetation $x$ \\
irrigation
\end{tabular} & 1 & 2.68 & 2.68 & 0.37 & 0.548 \\
\hline $\begin{array}{l}\text { Surface } x \\
\text { vegetation } x \\
\text { irrigation }\end{array}$ & 2 & 3.09 & 1.55 & 0.21 & 0.810 \\
\hline Error & 48 & 351.26 & 7.32 & & \\
\hline
\end{tabular}


Table 3-2. Surface Treatments Analysis of Variance, September 1988 to October 1989.

\begin{tabular}{|c|c|c|c|c|c|}
\hline \multicolumn{6}{|c|}{ CUMULATIVE STORAGE CHANGE } \\
\hline Source & DF & $\begin{array}{l}\text { Sum of } \\
\text { squares }\end{array}$ & Mean square & $\mathbf{F}$ & $\mathbf{P}$ \\
\hline Surface & 2 & $2,285.51$ & $1,142.76$ & 71.75 & 0.000 \\
\hline Vegetation & 1 & 389.12 & 389.12 & 24.43 & 0.000 \\
\hline Irrigation & 1 & 363.72 & 363.72 & 22.84 & 0.000 \\
\hline $\begin{array}{l}\text { Surface } x \\
\text { vegetation }\end{array}$ & 2 & 34.00 & 17.00 & 1.07 & 0.352 \\
\hline $\begin{array}{l}\text { Surface } x \\
\text { irrigation }\end{array}$ & 2 & 273.19 & 136.60 & 8.58 & 0.001 \\
\hline $\begin{array}{l}\text { Vegetation } x \\
\text { irrigation }\end{array}$ & 1 & 18.10 & 18.10 & 1.14 & 0.292 \\
\hline $\begin{array}{l}\text { Surface } x \\
\text { vegetation } x \\
\text { irrigation }\end{array}$ & 2 & 42.71 & 21.36 & 1.34 & 0.271 \\
\hline Error & 48 & 764.48 & 15.93 & & \\
\hline \multicolumn{6}{|c|}{ CUMULATIVE EVAPOTRANSPIRATION } \\
\hline Source & DF & $\begin{array}{l}\text { Sum of } \\
\text { squares }\end{array}$ & Mean square & $\mathbf{F}$ & $\mathbf{P}$ \\
\hline Surface & 2 & $2,283.64$ & $1,141.82$ & 72.08 & 0.000 \\
\hline Vegetation & 1 & 391.04 & 391.04 & 24.69 & 0.000 \\
\hline Irrigation & 1 & 690.92 & 690.92 & 43.62 & 0.000 \\
\hline $\begin{array}{l}\text { Surface } x \\
\text { vegetation }\end{array}$ & 2 & 33.36 & 16.68 & 1.05 & 0.357 \\
\hline $\begin{array}{l}\text { Surface } x \\
\text { irrigation }\end{array}$ & 2 & 272.11 & 136.05 & 8.59 & 0.001 \\
\hline $\begin{array}{l}\text { Vegetation } x \\
\text { irrigation }\end{array}$ & 1 & 18.57 & 18.57 & 1.17 & 0.284 \\
\hline $\begin{array}{l}\text { Surface } x \\
\text { vegetation } x \\
\text { irrigation }\end{array}$ & 2 & 43.54 & 21.77 & 1.37 & 0.263 \\
\hline Error & 48 & 760.38 & 15.84 & & \\
\hline
\end{tabular}


Table 3-3. Surface Treatments Analys is of Variance, September 1988 to May 1990.

\begin{tabular}{|c|c|c|c|c|c|}
\hline \multicolumn{6}{|c|}{ CUMULATIVE STORAGE CHANGE } \\
\hline Source & DF & $\begin{array}{l}\text { Sum of } \\
\text { squares }\end{array}$ & Mean square & $\mathbf{F}$ & $\mathbf{P}$ \\
\hline Surface & 2 & $4,864.25$ & $2,432.13$ & 145.97 & 0.000 \\
\hline Vegetation & 1 & 366.01 & 366.01 & 21.97 & 0.000 \\
\hline Irrigation & 1 & $1,766.78$ & $1,766.78$ & 106.04 & 0.000 \\
\hline $\begin{array}{l}\text { Surface } x \\
\text { vegetation }\end{array}$ & 2 & 113.74 & 56.87 & 3.41 & 0.041 \\
\hline $\begin{array}{l}\text { Surface } x \\
\text { irrigation }\end{array}$ & 2 & 916.48 & 458.24 & 27.50 & 0.000 \\
\hline $\begin{array}{l}\text { Vegetation } x \\
\text { irrigation }\end{array}$ & 1 & 22.03 & 22.03 & 1.32 & 0.256 \\
\hline $\begin{array}{l}\text { Surface } x \\
\text { vegetation } x \\
\text { irrigation }\end{array}$ & 2 & 31.32 & 15.66 & 0.94 & 0.398 \\
\hline Error & 48 & 799.79 & 16.66 & & \\
\hline \multicolumn{6}{|c|}{ CUMULATIVE EVAPOTRANSPIRATION } \\
\hline Source & DF & $\begin{array}{l}\text { Sum of } \\
\text { squares }\end{array}$ & Mean square & $\mathbf{F}$ & $\mathbf{P}$ \\
\hline Surface & 2 & $4,968.03$ & $2,484.01$ & 156.88 & 0.000 \\
\hline Vegetation & 1 & 383.94 & 383.94 & 24.25 & 0.000 \\
\hline Irrigation & 1 & $4,157.51$ & $4,157.51$ & 262.58 & 0.000 \\
\hline $\begin{array}{l}\text { Surface } x \\
\text { vegetation }\end{array}$ & 2 & 123.84 & 61.92 & 3.91 & 0.027 \\
\hline$\left\{\begin{array}{l}\text { Jur face } x \\
\text { irrigation }\end{array}\right.$ & 2 & 961.81 & 480.90 & 30.37 & 0.000 \\
\hline $\begin{array}{c}\text { Vegetation } x \\
\text { irrigation }\end{array}$ & 1 & 18.78 & 18.78 & 1.19 & 0.282 \\
\hline $\begin{array}{l}\text { Surface } x \\
\text { vegetation } x \\
\text { irrigation }\end{array}$ & 2 & 25.80 & 12.90 & 0.815 & 0.449 \\
\hline Error & 48 & 760.00 & 15.83 & & \\
\hline
\end{tabular}


Table 3-4. Surface Treatments Analysis of Variance, September 1988 to October 1990.

\begin{tabular}{|c|c|c|c|c|c|}
\hline \multicolumn{6}{|c|}{ CUMULATIVE STORAGE CHANGE } \\
\hline Source & DF & $\begin{array}{l}\text { Sum of } \\
\text { squares }\end{array}$ & Mean square & $F$ & $\mathbf{P}$ \\
\hline Surface & 2 & $5,094.33$ & $2,547.17$ & 138.42 & 0.000 \\
\hline Vegetation & 1 & 429.59 & 429.59 & 23.25 & 0.000 \\
\hline Irrigation & 1 & 891.25 & 891.25 & 48.43 & 0.000 \\
\hline $\begin{array}{l}\text { Surface } x \\
\text { vegetation }\end{array}$ & 2 & 105.51 & 52.76 & 2.87 & 0.067 \\
\hline $\begin{array}{l}\text { Surface } x \\
\text { irrigation }\end{array}$ & 2 & 904.60 & 452.30 & 24.58 & 0.000 \\
\hline $\begin{array}{l}\text { Vegetation } x \\
\text { irrigation }\end{array}$ & 1 & 22.83 & 22.83 & 1.24 & 0.271 \\
\hline $\begin{array}{l}\text { Surface } x \\
\text { vegetation } x \\
\text { irrigation }\end{array}$ & 2 & 77.18 & 38.59 & 2.10 & 0.134 \\
\hline Error & 48 & 883.27 & 18.40 & & \\
\hline \multicolumn{6}{|c|}{ CUMULATIVE EVAPOTRANSPIRATION } \\
\hline Source & DF & $\begin{array}{l}\text { Sum of } \\
\text { squares }\end{array}$ & Mean square & $\mathbf{F}$ & $\mathbf{P}$ \\
\hline Surface & 2 & $5,267.43$ & $2,633.71$ & 150.76 & 0.000 \\
\hline Vegetation & 1 & 472.84 & 472.84 & 27.07 & 0.000 \\
\hline Irrigation & 1 & $7,999.65$ & $7,999.65$ & 457.93 & 0.000 \\
\hline $\begin{array}{l}\text { Surface } x \\
\text { vegetation }\end{array}$ & 2 & 123.99 & 62.00 & 3.55 & 0.037 \\
\hline $\begin{array}{l}\text { Surface } x \\
\text { irrigation }\end{array}$ & 2 & $1,000.51$ & 500.26 & 28.64 & 0.000 \\
\hline $\begin{array}{l}\text { Vegetation } x \\
\text { irrigation }\end{array}$ & 1 & 16.93 & 16.93 & 0.97 & 0.330 \\
\hline $\begin{array}{l}\text { Surface } x \\
\text { vegetation } x \\
\text { irrigation }\end{array}$ & 2 & 61.51 & 30.76 & 1.761 & 0.183 \\
\hline Error & 48 & 838.52 & 17.47 & & \\
\hline
\end{tabular}


WHC-EP-0597

Table 3-5. Surface Treatments Analysis of Variance, September 1988 to March 1991.

\begin{tabular}{|c|c|c|c|c|c|}
\hline \multicolumn{6}{|c|}{ CUMULATIVE STORAGE CHANGE } \\
\hline Source & DF & $\begin{array}{l}\text { Sum of } \\
\text { squares }\end{array}$ & Mean square & $F$ & $P$ \\
\hline Surface & 2 & $5,336.36$ & $2,668.18$ & 154.56 & 0.000 \\
\hline Vegetation & 1 & 178.27 & 178.27 & 10.33 & 0.002 \\
\hline Irrigation & 1 & $4,005.78$ & $4,005.78$ & 232.05 & 0.000 \\
\hline $\begin{array}{l}\text { Surface } x \\
\text { vegetation }\end{array}$ & 2 & 78.98 & 39.49 & 2.29 & 0.112 \\
\hline $\begin{array}{l}\text { Surface } x \\
\text { irrigation }\end{array}$ & 2 & 438.19 & 219.10 & 12.69 & 0.000 \\
\hline $\begin{array}{l}\text { Vegetation } x \\
\text { irrigation }\end{array}$ & 1 & 78.62 & 78.62 & 4.55 & 0.038 \\
\hline $\begin{array}{l}\text { Surface } x \\
\text { vegetation } x \\
\text { irrigation }\end{array}$ & 2 & 156.34 & 78.17 & 4.53 & 0.016 \\
\hline Error & 48 & 828.61 & 17.26 & & \\
\hline \multicolumn{6}{|c|}{ CUMULATIVE EVAPOTRANSPIRATION } \\
\hline Source & DF & $\begin{array}{l}\text { Sum of } \\
\text { squares }\end{array}$ & Mean square & $\mathbf{F}$ & $\mathbf{P}$ \\
\hline Surface & 2 & $5,884.33$ & $2,942.16$ & 198.75 & 0.000 \\
\hline Vegetation & 1 & 232.23 & 232.23 & 15.69 & 0.000 \\
\hline Irrigation & 1 & $17,300.02$ & $17,300.02$ & $1,168.67$ & 0.000 \\
\hline $\begin{array}{l}\text { Surface } x \\
\text { vegetation }\end{array}$ & 2 & 116.86 & 58.43 & 3.95 & 0.026 \\
\hline $\begin{array}{l}\text { Surface } x \\
\text { irrigation }\end{array}$ & 2 & 622.38 & 311.19 & 21.02 & 0.000 \\
\hline $\begin{array}{l}\text { Vegetation } x \\
\text { irrigation }\end{array}$ & 1 & 53.78 & 53.78 & 3.63 & 0.063 \\
\hline $\begin{array}{l}\text { Surface } x \\
\text { vegetation } x \\
\text { irrigation }\end{array}$ & 2 & 107.92 & 53.96 & 3.65 & 0.034 \\
\hline Error & 48 & 710.55 & 14.80 & & \\
\hline
\end{tabular}


Table 3-6. Surface Treatments Analysis of Variance, September 1988 to September 1991.

\begin{tabular}{|c|c|c|c|c|c|}
\hline \multicolumn{6}{|c|}{ CUMULATIVE STORAGE CHANGE } \\
\hline Source & DF & $\begin{array}{l}\text { Sum of } \\
\text { squares }\end{array}$ & Mean square & $F$ & $\mathbf{P}$ \\
\hline Surface & 2 & $7,711.09$ & $3,855.54$ & 125.62 & 0.000 \\
\hline Vegetation & 1 & $1,939.09$ & $1,939.09$ & 63.18 & 0.000 \\
\hline Irrigation & 1 & 353.50 & .353 .50 & 11.52 & 0.001 \\
\hline $\begin{array}{l}\text { Surface } x \\
\text { vegetation }\end{array}$ & 2 & 50.42 & 25.21 & 0.82 & 0.446 \\
\hline $\begin{array}{l}\text { Surface } x \\
\text { irrigation }\end{array}$ & 2 & 809.05 & 404.52 & 13.18 & 0.000 \\
\hline $\begin{array}{l}\text { Vegetation } x \\
\text { irrigation }\end{array}$ & 1 & 17.82 & 17.82 & 0.58 & 0.450 \\
\hline $\begin{array}{l}\text { Surface } x \\
\text { vegetation } x \\
\text { irrigation }\end{array}$ & 2 & 538.44 & 269.22 & 8.77 & 0.001 \\
\hline Error & 48 & $1,473.26$ & 30.69 & & \\
\hline \multicolumn{6}{|c|}{ CUMULATIVE EVAPOTRANSPIRATION } \\
\hline Source & DF & $\begin{array}{l}\text { Sum of } \\
\text { squares }\end{array}$ & Mean square & $F$ & $P$ \\
\hline Surface & 2 & $8,712.88$ & $4,356.44$ & 158.00 & 0.000 \\
\hline Vegetation & 1 & $2,175.35$ & $2,175.35$ & 78.90 & 0.000 \\
\hline Irrigation & 1 & $42,818.31$ & $42,818.31$ & $1,552.98$ & 0.000 \\
\hline $\begin{array}{l}\text { Surface } x \\
\text { vegetation }\end{array}$ & 2 & 75.54 & 37.77 & 1.37 & 0.264 \\
\hline $\begin{array}{l}\text { Surface } x \\
\text { irrigation }\end{array}$ & 2 & $1,162.80$ & 581.40 & 21.09 & 0.000 \\
\hline $\begin{array}{l}\text { Vegetation } x \\
\text { irrigation }\end{array}$ & 1 & 39.76 & 39.76 & 1.44 & 0.236 \\
\hline $\begin{array}{l}\text { Surface } x \\
\text { vegetation } x \\
\text { irrigation }\end{array}$ & 2 & 408.93 & 204.46 & 7.42 & 0.002 \\
\hline Error & 48 & $1,323.44$ & 27.57 & & \\
\hline
\end{tabular}


Table 3-7. Surface Treatments Analysis of Variance, September 1988 to March 1992.

\begin{tabular}{|c|c|c|c|c|c|}
\hline \multicolumn{6}{|c|}{ CUMULATIVE STORAGE CHANGE } \\
\hline Source & DF & $\begin{array}{l}\text { Sum of } \\
\text { squares }\end{array}$ & Mean square & $\mathbf{F}$ & $\mathbf{P}$ \\
\hline Surface & 2 & $7,209.60$ & $3,604.80$ & 132.19 & 0.000 \\
\hline Vegetation & 1 & $1,233.98$ & $1,233.98$ & 45.25 & 0.000 \\
\hline Irrigation & 1 & $1,557.52$ & $1,557.52$ & 57.12 & 0.000 \\
\hline $\begin{array}{l}\text { Surface } x \\
\text { vegetation }\end{array}$ & 2 & 50.40 & 25.20 & 0.92 & 0.404 \\
\hline $\begin{array}{l}\text { Surface } x \\
\text { irrigation }\end{array}$ & 2 & 338.91 & 169.46 & 6.21 & 0.004 \\
\hline $\begin{array}{l}\text { Vegetation } x \\
\text { irrigation }\end{array}$ & 1 & 0.87 & 0.87 & 0.03 & 0.859 \\
\hline $\begin{array}{l}\text { Surface } x \\
\text { vegetation } x \\
\text { irrigation }\end{array}$ & 2 & 789.69 & 394.84 & 14.48 & 0.000 \\
\hline Error & 48 & $1,308.91$ & 27.27 & & \\
\hline \multicolumn{6}{|c|}{ CUMULATIVE EVAPOTRANSPIRATION } \\
\hline Source & DF & $\begin{array}{l}\text { Sum of } \\
\text { squares }\end{array}$ & Mean square & $\mathbf{F}$ & $\mathbf{P}$ \\
\hline Surface & 2 & $8,550.32$ & $4,275.16$ & 189.28 & 0.000 \\
\hline Vegetation & 1 & $1,488.92$ & $1,488.92$ & 65.92 & 0.000 \\
\hline Irrigation & 1 & $55,771.09$ & $55,771.09$ & $2,469.17$ & 0.000 \\
\hline $\begin{array}{l}\text { Surface } x \\
\text { vegetation }\end{array}$ & 2 & 94.12 & 47.06 & 2.08 & 0.136 \\
\hline $\begin{array}{l}\text { Surface } x \\
\text { irrigation }\end{array}$ & 2 & 631.46 & 315.73 & 13.98 & 0.000 \\
\hline $\begin{array}{l}\text { Vegetation } x \\
\text { irrigation }\end{array}$ & 1 & 1.77 & 1.77 & 0.08 & 0.781 \\
\hline $\begin{array}{l}\text { Surface } x \\
\text { vegetation } x \\
\text { irrigation }\end{array}$ & 2 & 618.35 & 309.17 & 13.69 & 0.000 \\
\hline Error & 48 & $1,084.18$ & 22.59 & & \\
\hline
\end{tabular}


Figure 3-3. Surface Treatments Storage Change Differences, September 1988 to May 1989.

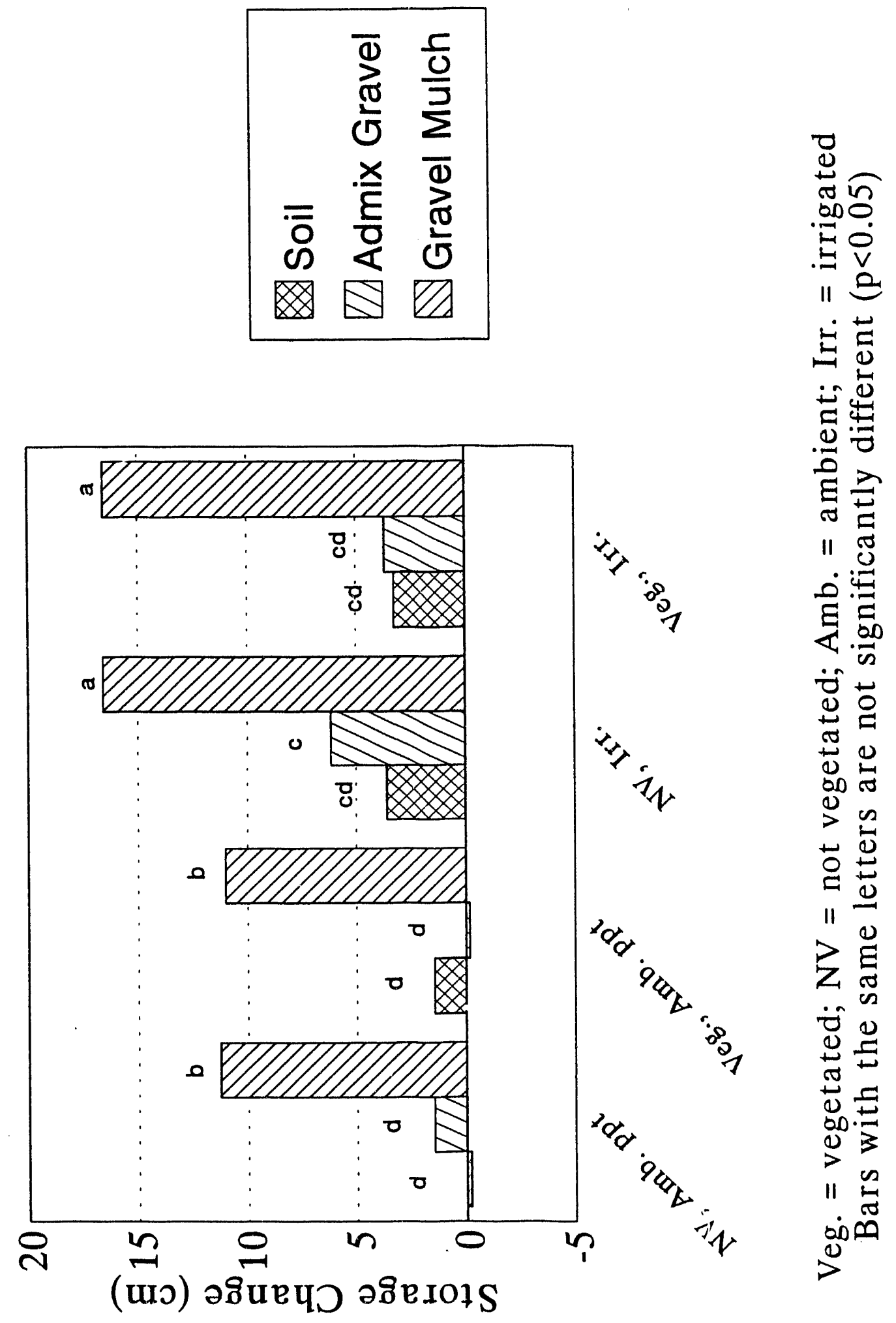


Figure 3-4. Surface Treatments Total Evapotranspiration Differences, September 1988 to May 1989.

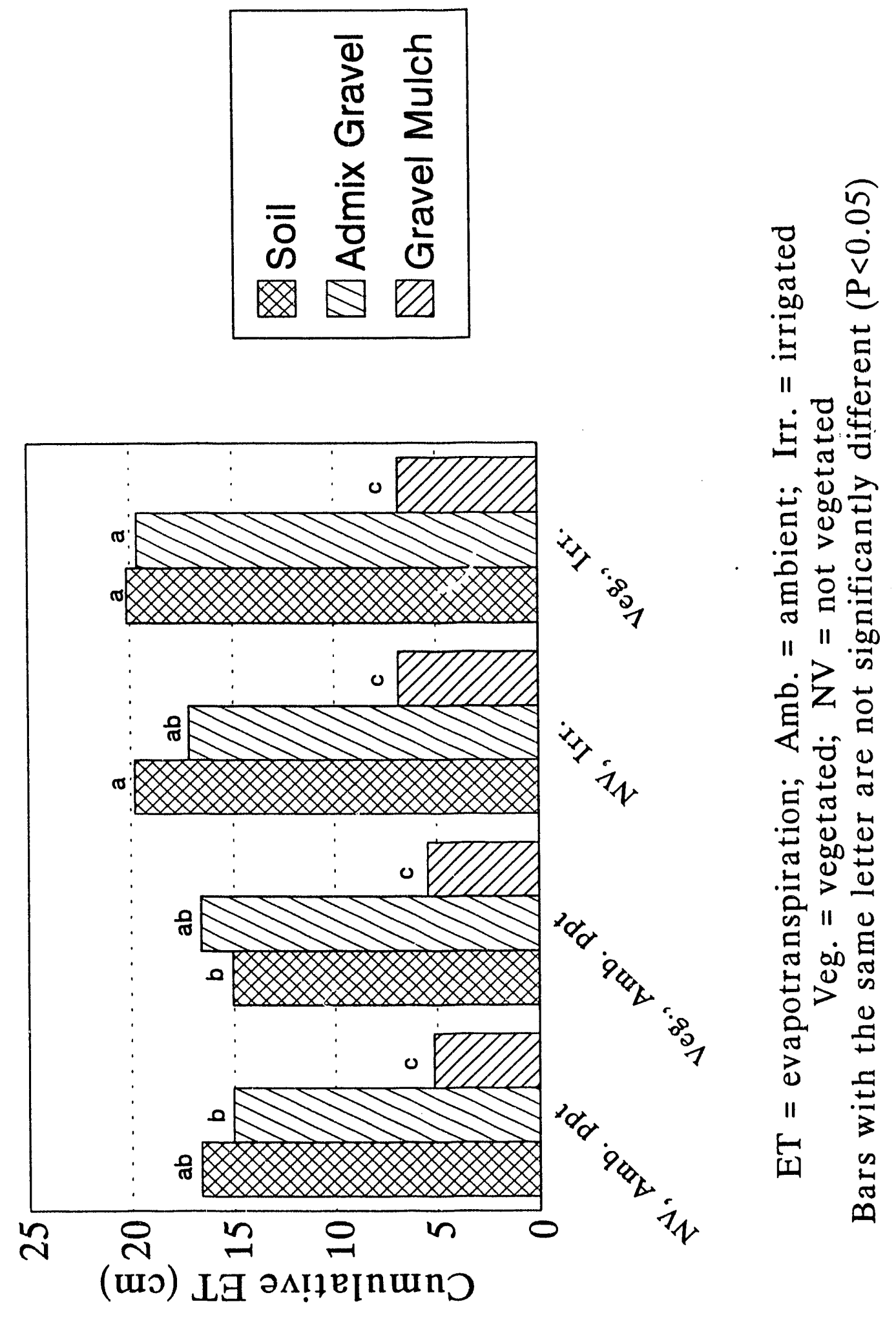


Figure 3-5. Surface Treatments Storage Change Differences, September 1988 to October 1989.

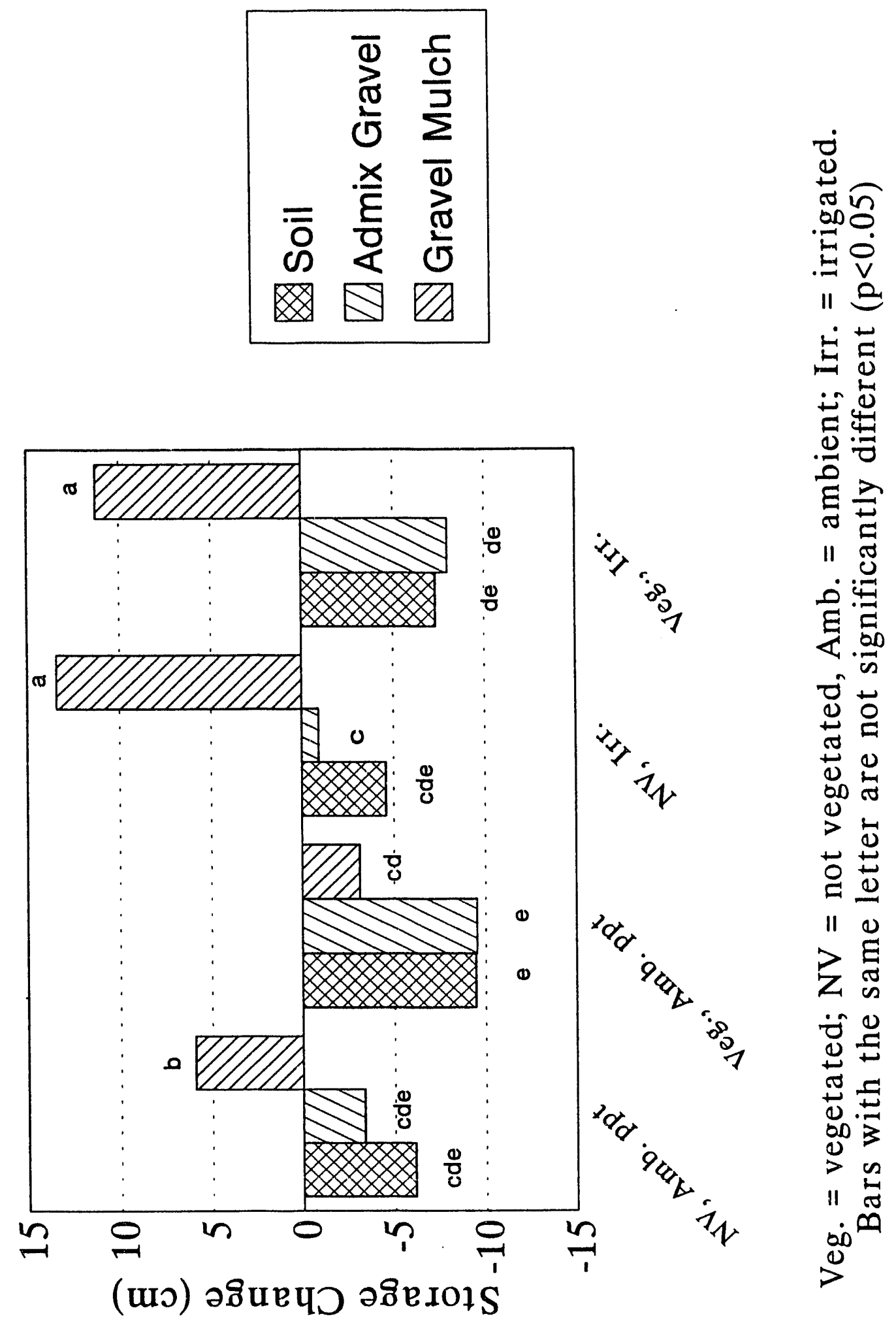


Figure 3-6. Surface Treatments Total Evapotranspiration Differences, September 1988 to October 1989.

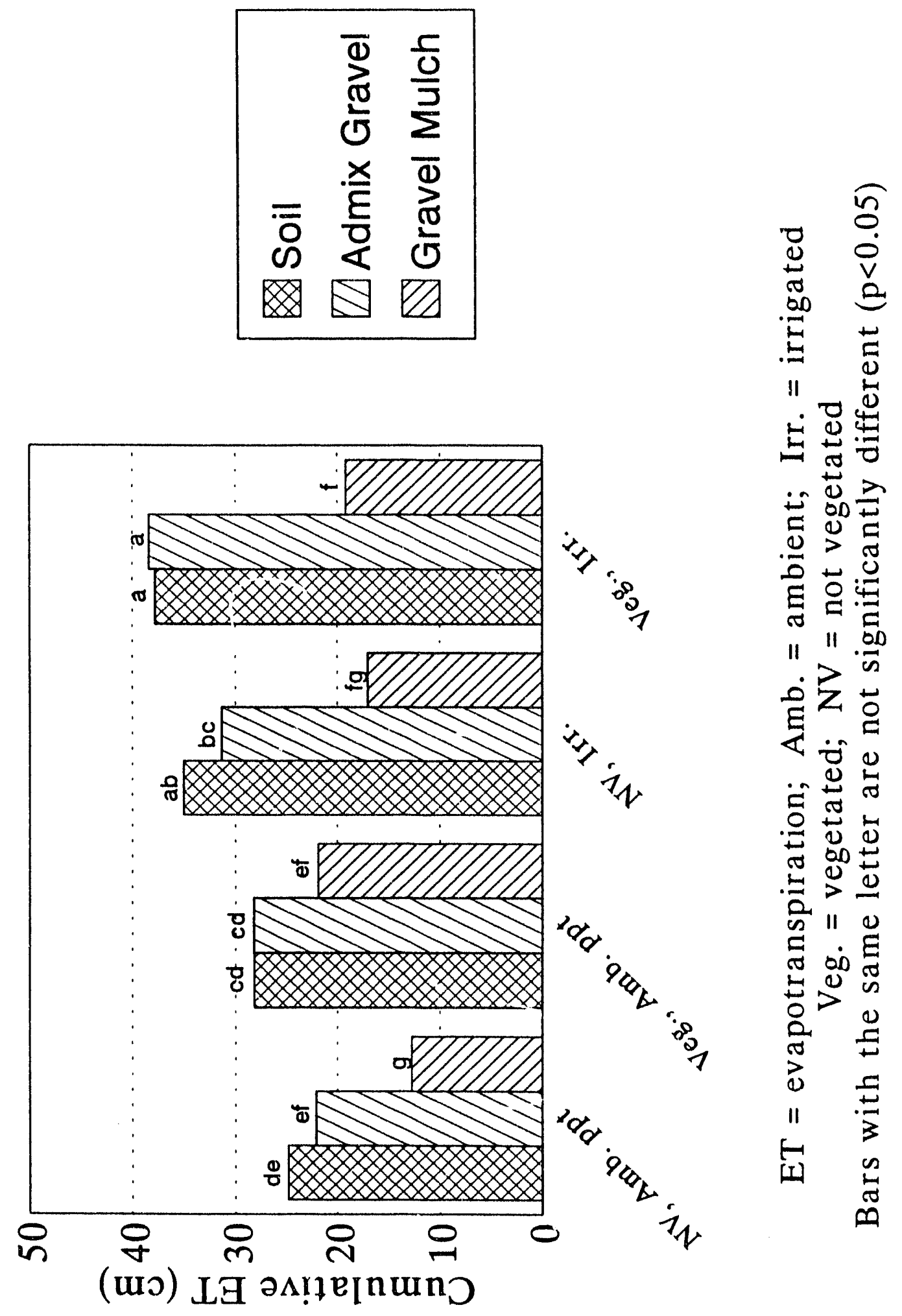


Figure 3-7. Surface Treatments Storage Change Differences, September 1988 to May 1990.

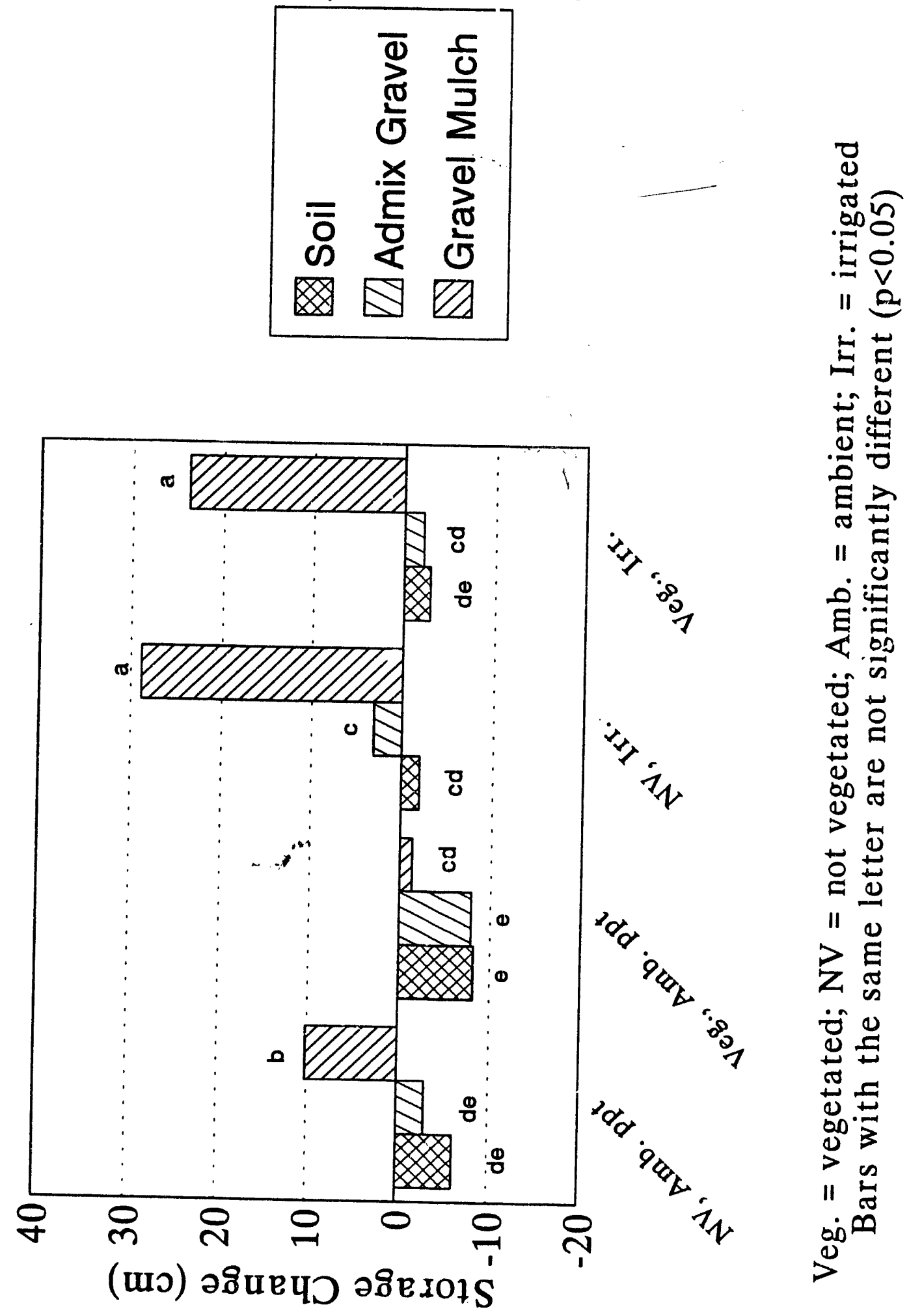


Figure 3-8. Surface Treatments Total Evapotranspiration Differences, September 1988 to May 1990.

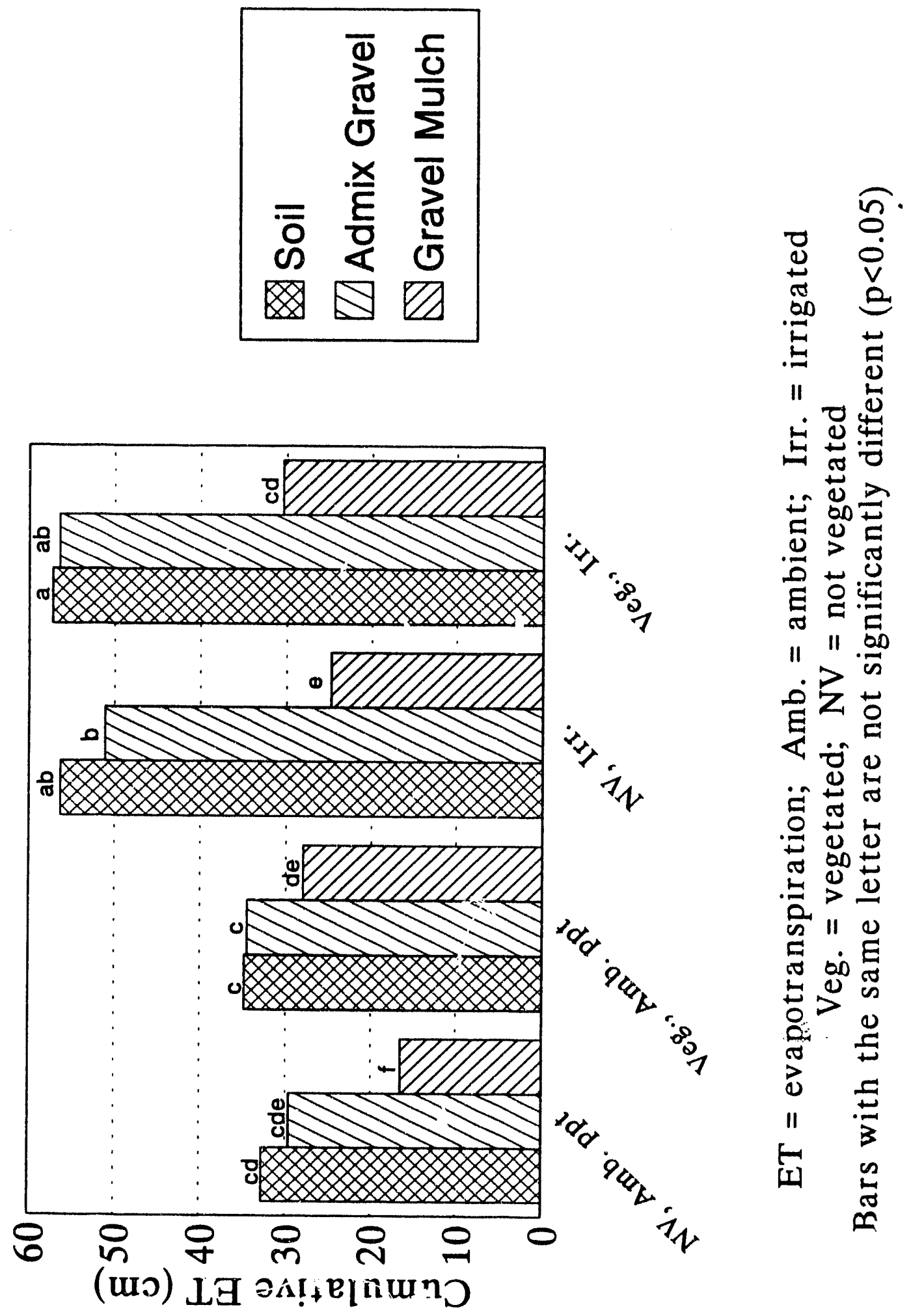


Figure 3-9. Surface Treatments Storage Change Differences, September 1988 to October 1990.

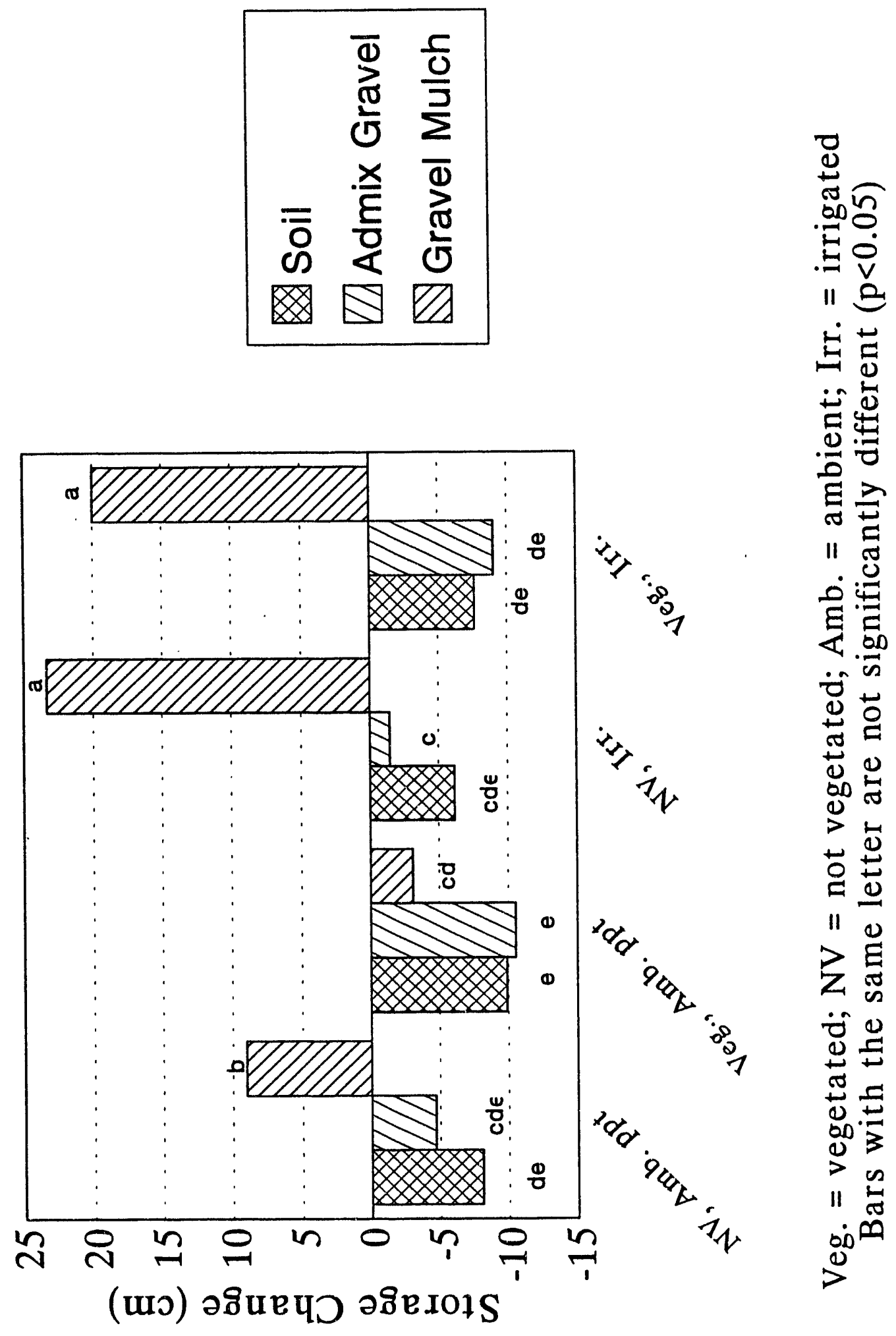


Figure 3-10. Surface Treatments Total Evapotranspiration Differences, September 1988 to October 1990.

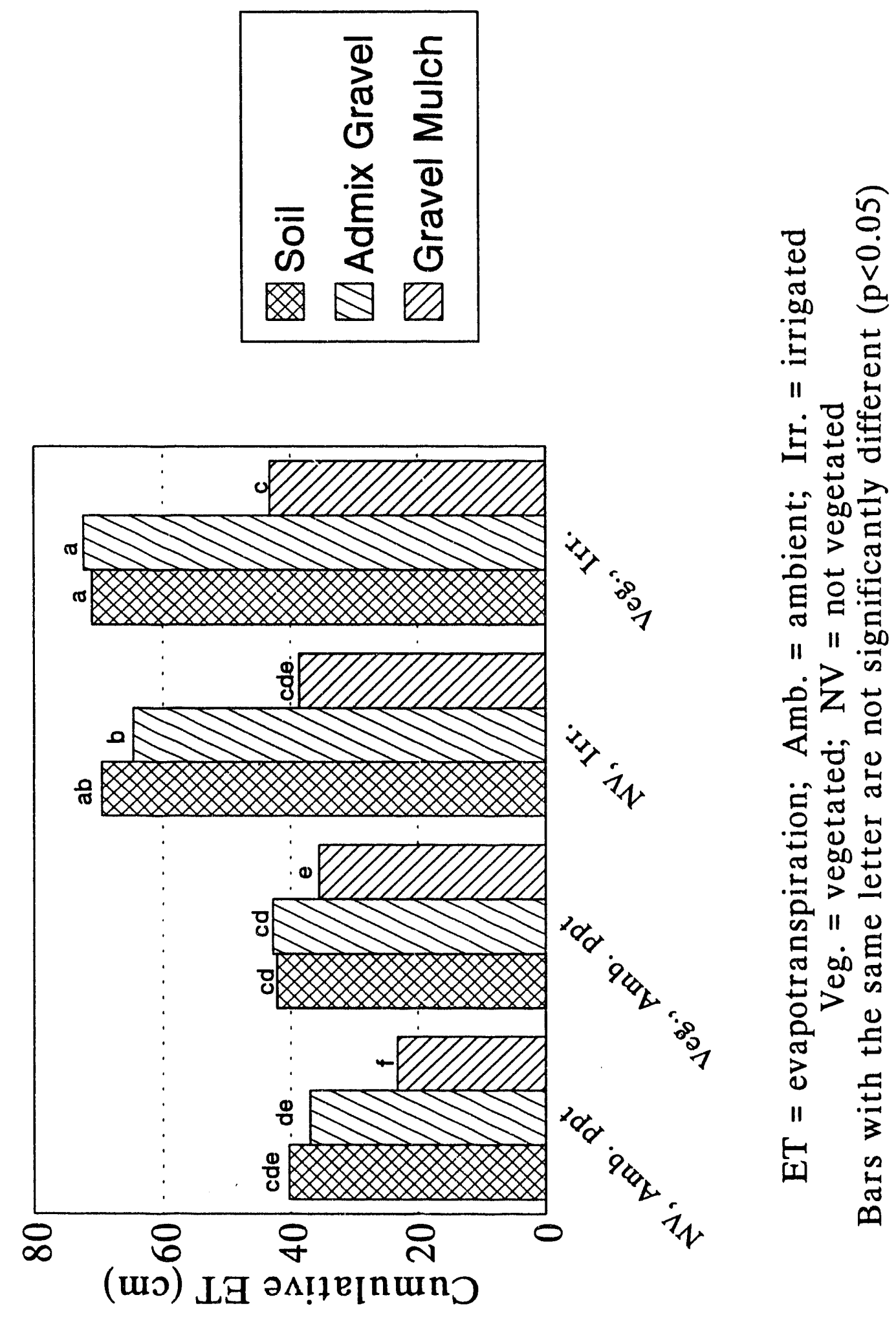


WHC-EP-0597

Figure 3-11. Surface Treatments Storage Change Differences, September 1988 to March 1991.

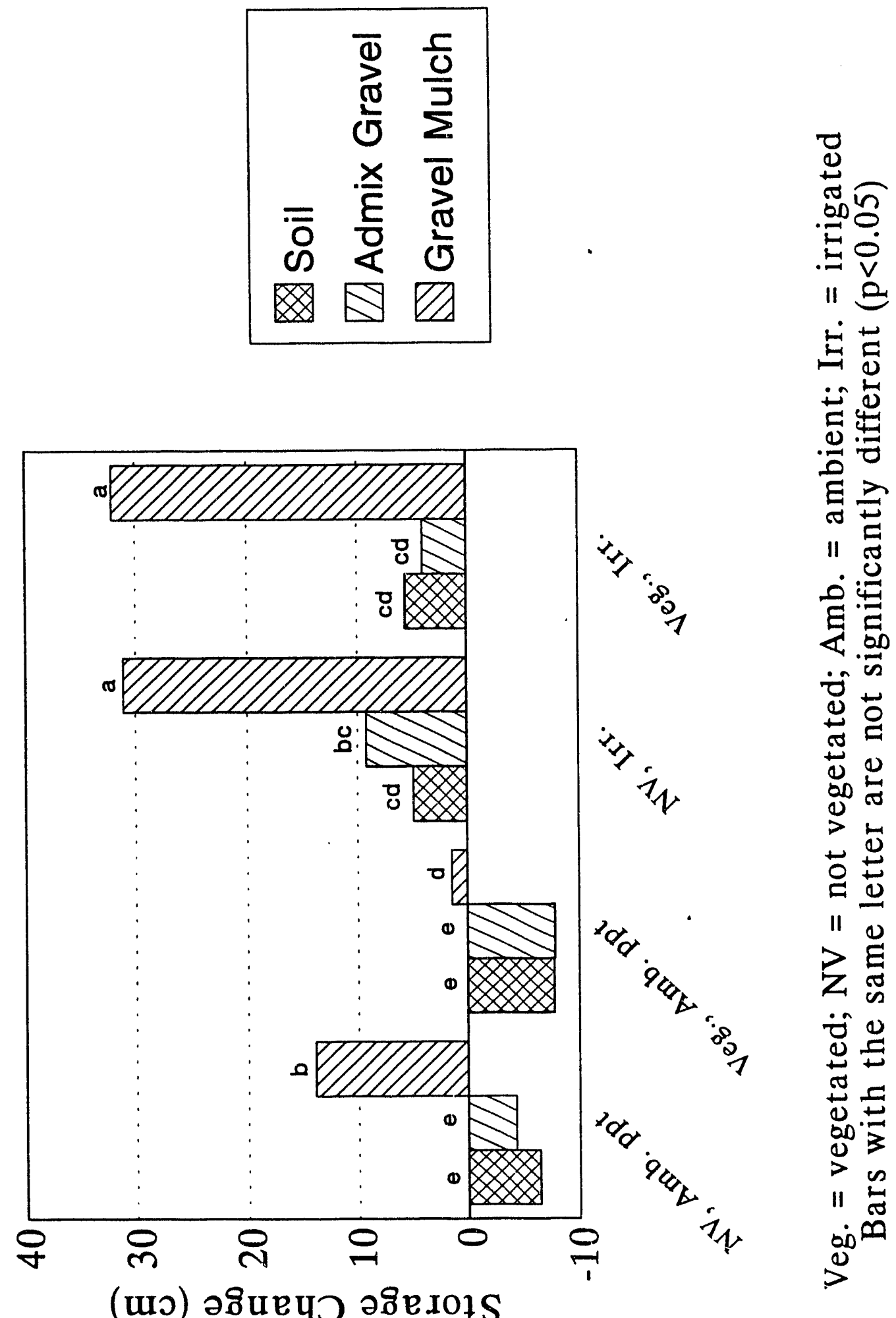


Figure 3-12. Surface Treatments Total Evapotranspiration Differences, September 1988, to March 1991.

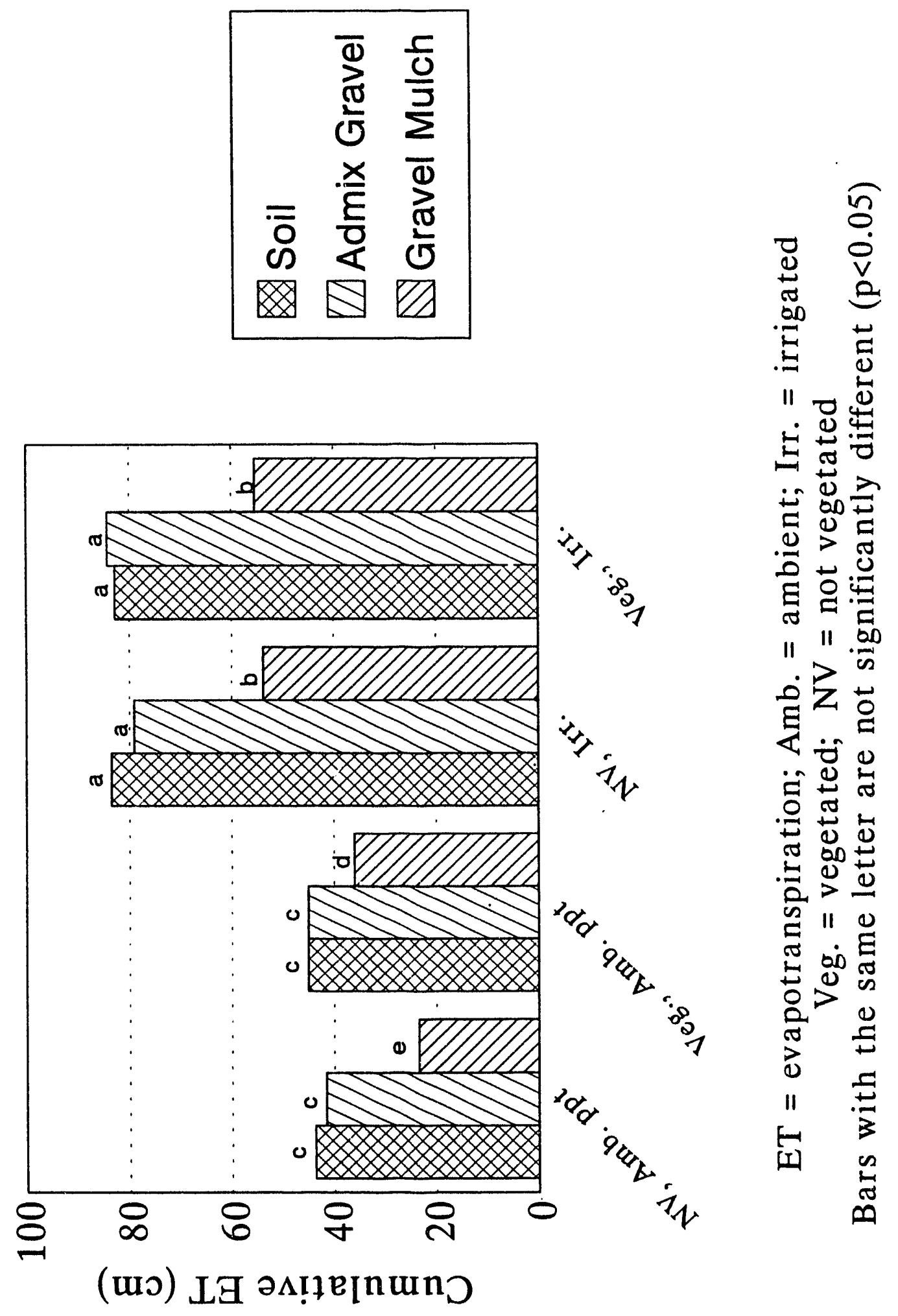


Figure 3-13. Surface Treatments Storage Change Differences, September 1988 to September 1991.

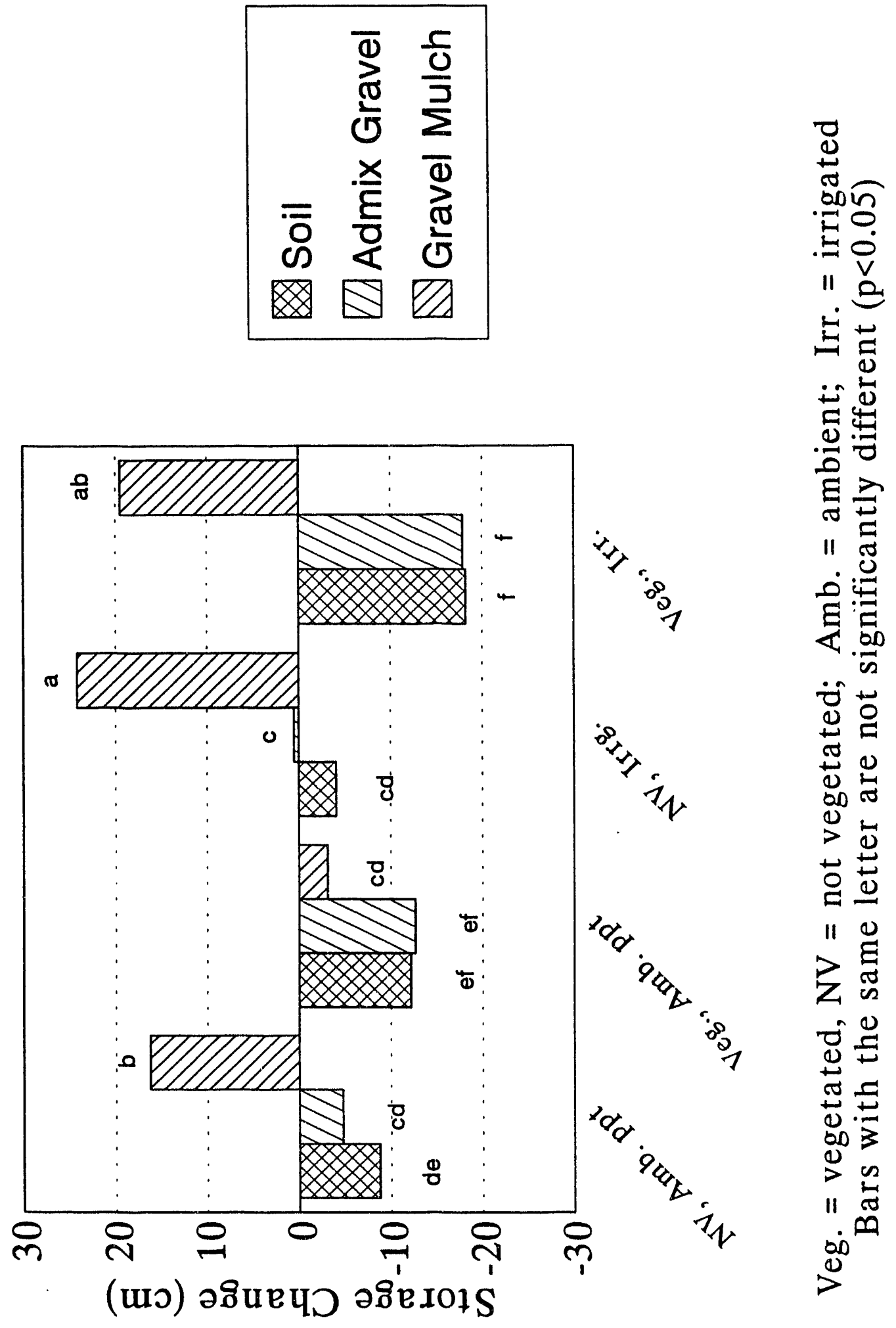


Figure 3-14. Surface Treatments Total Evapotranspiration Differences, September 1988 to September 1991.

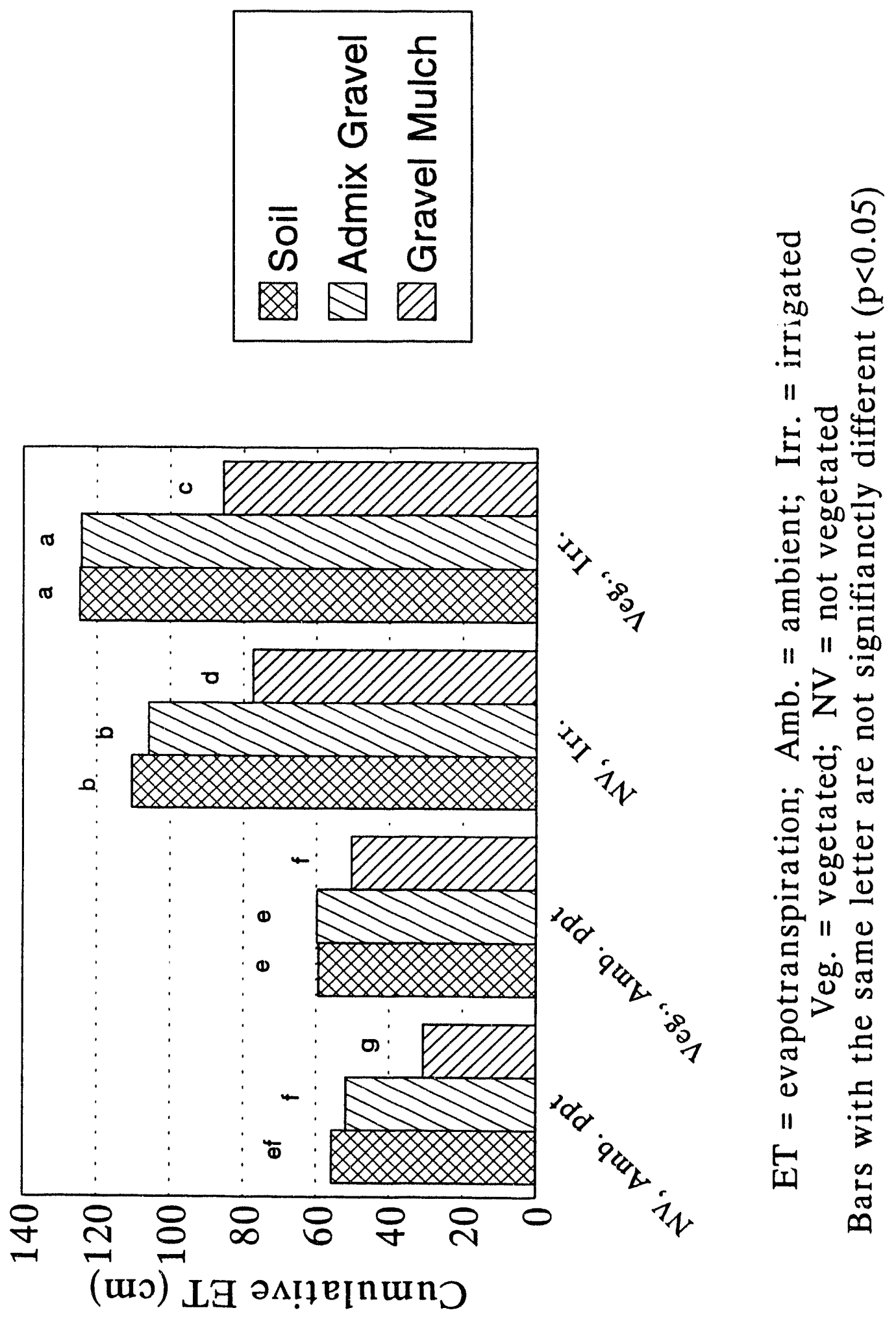


Figure 3-15. Surface Treatments Storage Change Differences, September 1988 to March 1992.

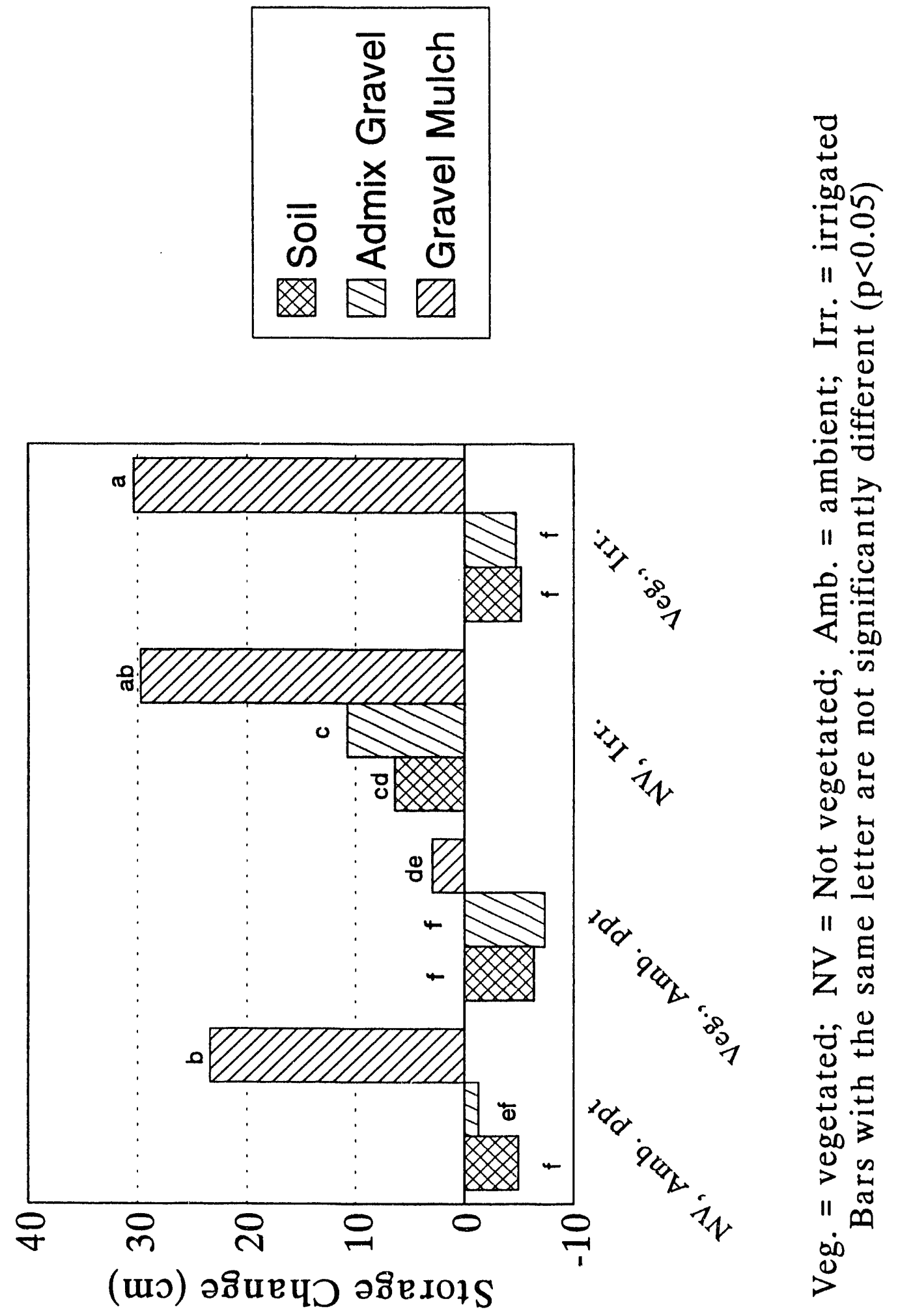


Figure 3-16. Surface Treatments Total Evapotranspiration Differences, September 1988 to March 1992.

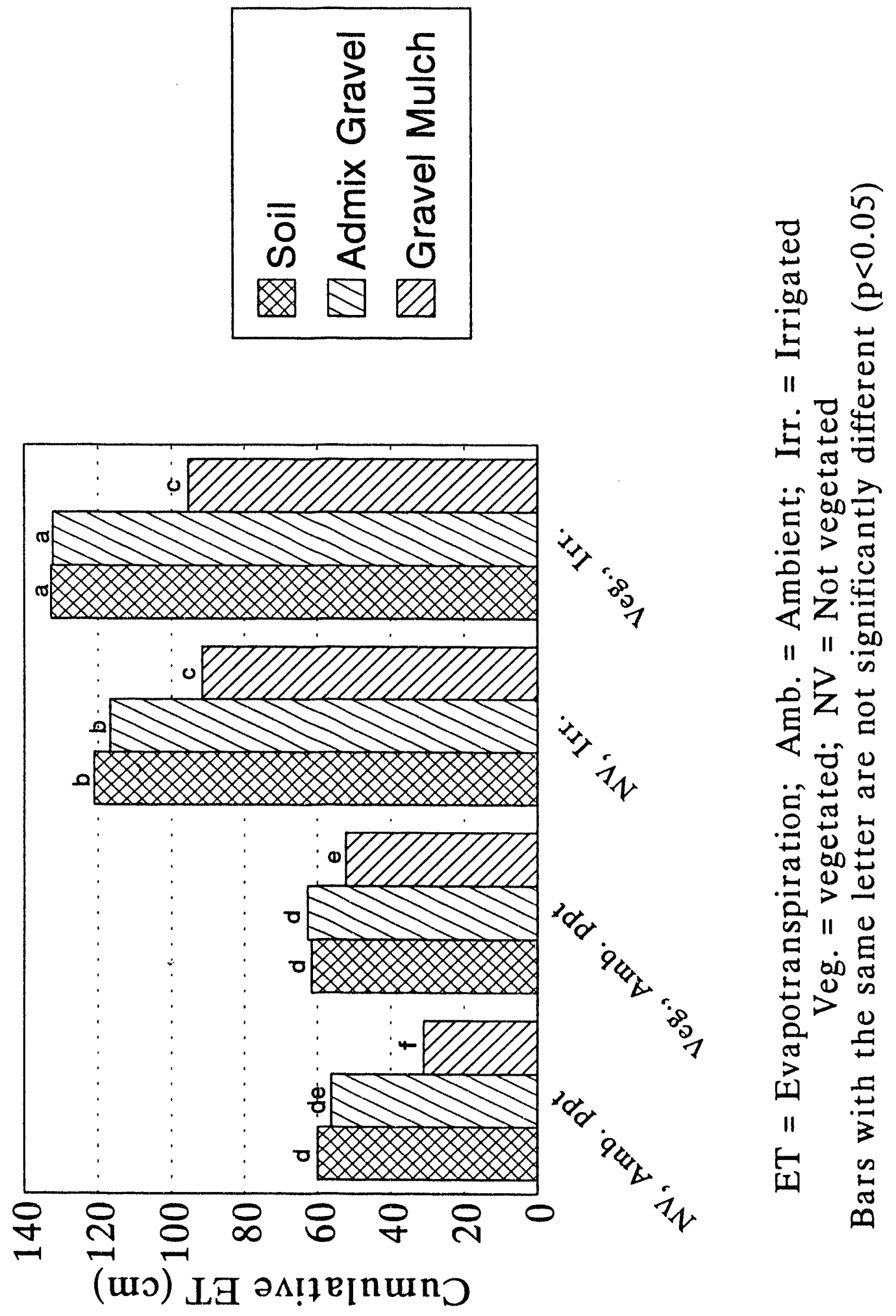


All of the gravel mulch treatments, except the nonirrigated, vegetated gravel mulch treatment, have produced detectable amounts of drainage. The irrigated, nonvegetated treatment had the greatest amount of drainage, followed by the irrigated, vegetated, and the nonirrigated, nonvegetated treatments (Figure 3-17). Although the mean differences among these treatments may appear fairly large, the differences among the gravel mulch treatments are not statistically different because of the large amount of within-treatment variation. In fact, only the irrigated, nonvegetated treatment is significantly greater than the soil or admix treatments, none of which has produced any detectable drainage.

\subsection{SAND AND GRAVEL DEPOSITION LAYERS}

The long-term patterns for drainage, storage change, and ET for the gravel and sand deposition treatments are shown in Figures 3-17, 3-18, and $3-19$, respectively. The sand-covered, nonvegetated treatment had the highest mean cumulative drainage, although this was not significantly different from the nonvegetated, gravel mulch treatment. The presence of vegetation greatly decreases the amount of mean drainage, but the large amount of variation among the lysimeters within each treatment obscures the differences in the means. For the sand-covered lysimeters, the amount of drainage from the vegetated and nonvegetated lysimeters is significantly different, but this is not true for the gravel mulch lysimeters. In general, the values of storage and ET are similar for the sand and gravel treatments, because the storage value is much higher and the ET value is much lower under these treatments than under the control treatments, which in this case are vegetated and nonvegetated, irrigated, plain soil surface treatments.

The statistical analyses for storage and ET on the selected analysis dates are presented in Tables 3-8 through 3-14. The treatment means and indications of statistically significant differences are shown graphicaliy in Figure 3-20 (Storage) and Figure 3-21 (ET). In this case bars within a sampling date labeled with the same letters are not significantly different at $p \leq 0.05$.

The surface treatment main effect was always significant, almost entirely because of the large differences between the sand or gravel treatments and the plain soil control. In general the sand-covered and gravel mulch lysimeters had very similar values for storage and ET; when significant differences do occur the sand treatment usually has a lower storage and/or higher ET than the comparable gravel mulch treatment. The vegetation main effect was often significant, with the vegetated lysimeters having lower storage and higher ET than the nonvegetated treatments. The analysis dates that did not show a significant vegetation effect all occurred in the spring, after the period of the greatest water input and the least potential ET. The interaction effect of surface type $X$ vegetation was never significant for either ET or storage change. 
Figure 3-17. Irrigated Gravel and Sand Treatments Cumulative Drainage.

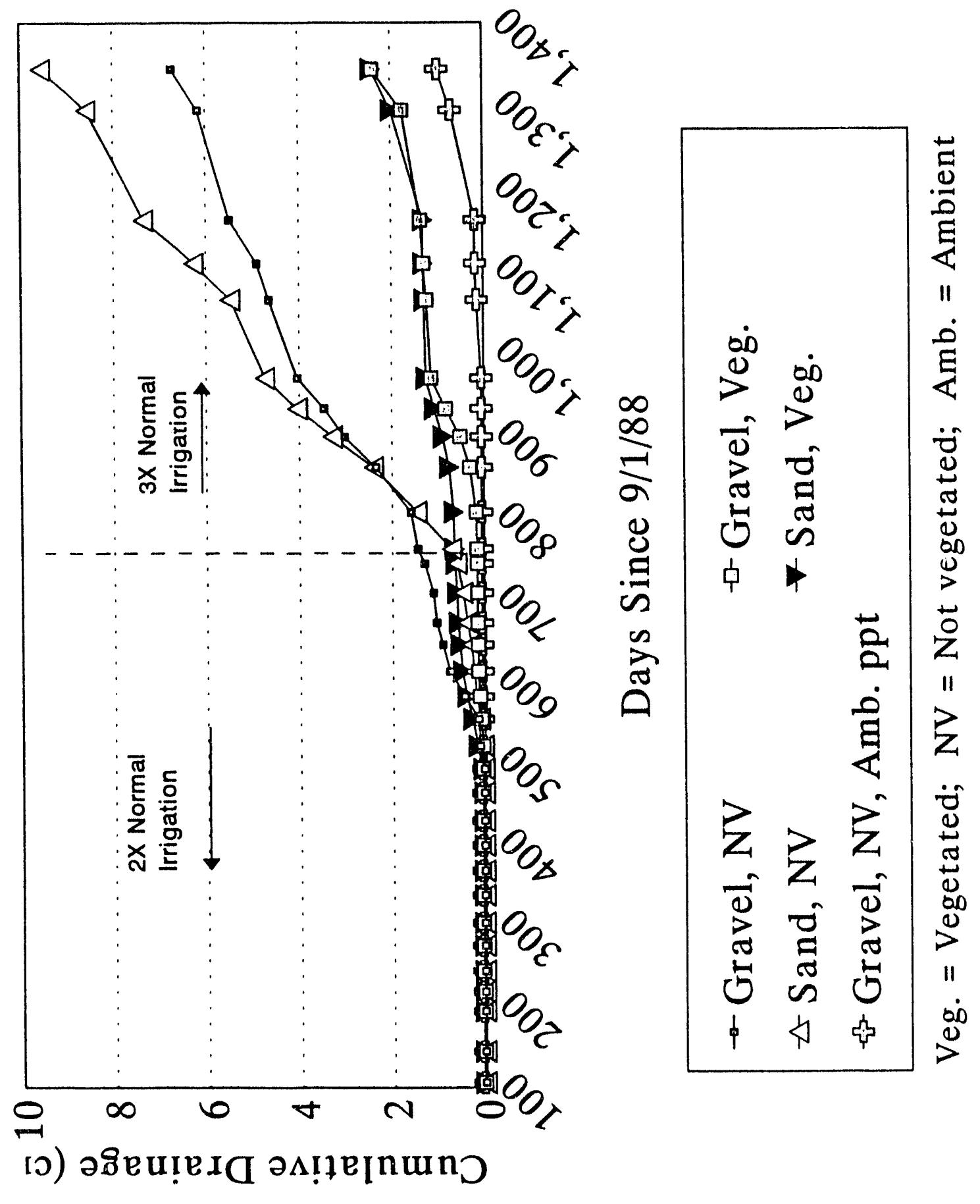


WHC-EP-0597

Figure 3-18. Irrigated Gravel and Sand Treatments Cumulative Storage Change.

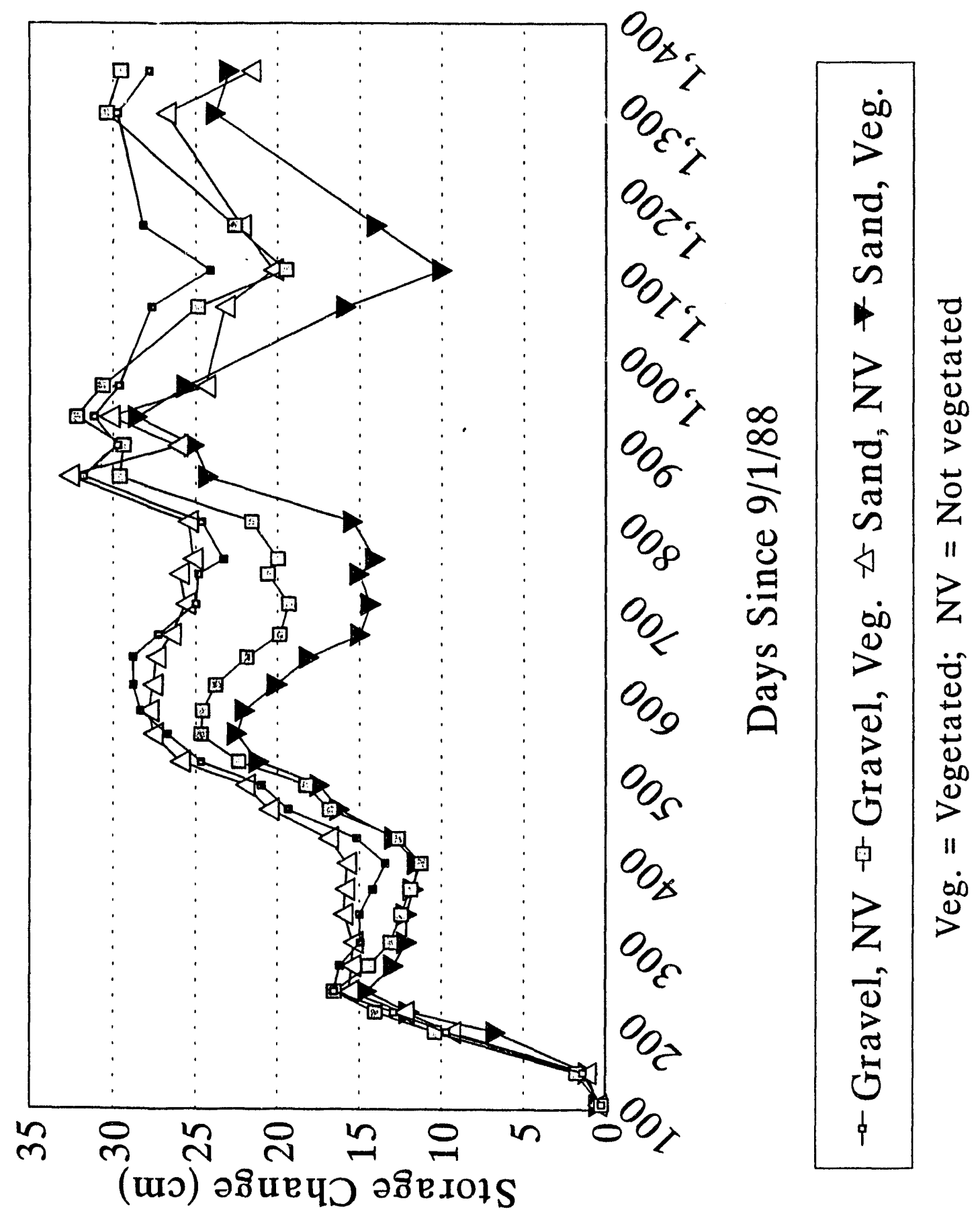

$3-27$ 
Figure 3-19. Irrigated Gravel and Sand Treatments Cumulative Evapotranspiration.

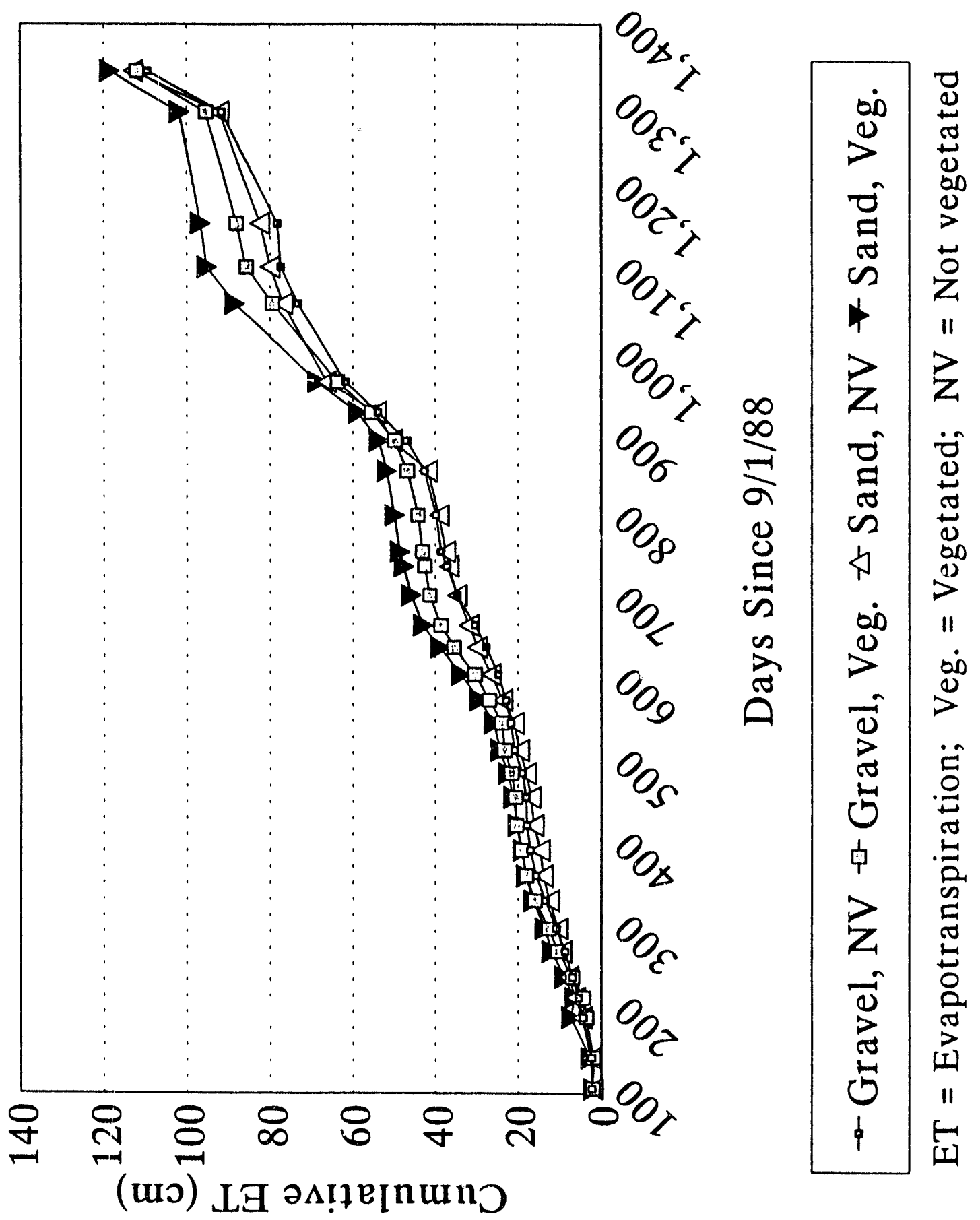


Table 3-8. Sand and Gravel Mulches Analysis of Variance, September 1988 to May 1989.

\begin{tabular}{|c|c|c|c|c|c|}
\hline \multicolumn{6}{|c|}{ CUMULATIVE STORAGE CHANGE } \\
\hline Source & DF & $\begin{array}{l}\text { Sum of } \\
\text { squares }\end{array}$ & Mean square & $\mathbf{F}$ & $P$ \\
\hline Vegetation & 1 & 1.74 & 1.74 & 0.43 & 0.517 \\
\hline Surface type & 2 & $1,035.32$ & 517.66 & 128.75 & 0.000 \\
\hline $\begin{array}{l}\text { Vegetation } x \\
\text { surface }\end{array}$ & 2 & 1.53 & 0.77 & 0.19 & 0.828 \\
\hline Error & 24 & 96.49 & 4.02 & & \\
\hline \multicolumn{6}{|c|}{ CUMULATIVE EVAPOTRANSPIRATION } \\
\hline Source & DF & $\begin{array}{l}\text { Sum of } \\
\text { squares }\end{array}$ & Mean square & $\mathbf{F}$ & $P$ \\
\hline Vegetation & 1 & 1.64 & 1.64 & 0.41 & 0.528 \\
\hline Surface type & 2 & $1,037.71$ & 518.86 & 129.77 & 0.000 \\
\hline $\begin{array}{l}\text { Vegetation } x \\
\text { surface }\end{array}$ & 2 & 3.51 & 0.76 & 0.189 & 0.829 \\
\hline Error & 24 & 95.96 & 4.00 & & \\
\hline
\end{tabular}

Table 3-9. Sand and Gravel Mulches Analysis of Variance, September 1988 to October 1989.

\begin{tabular}{|c|c|c|c|c|c|}
\hline \multicolumn{6}{|c|}{ CUMULATIVE STORAGE CHANGL } \\
\hline Source & DF & $\begin{array}{l}\text { Sum of } \\
\text { squares }\end{array}$ & Mean square & $\mathbf{F}$ & $\mathbf{P}$ \\
\hline Vegetation & 1 & 70.80 & 70.80 & 6.38 & 0.019 \\
\hline Surface type & 2 & $2,403.15$ & $1,201.57$ & 108.26 & 0.000 \\
\hline $\begin{array}{l}\text { Vegetation } x \\
\text { surface }\end{array}$ & $\overline{2}$ & 6.09 & 3.04 & 0.27 & 0.762 \\
\hline Error & 24 & 266.36 & 11.10 & & \\
\hline \multicolumn{6}{|c|}{ CUMUI.ATIVE EVAPOTRANSPIRATION } \\
\hline Source & DF & $\begin{array}{l}\text { Sum of } \\
\text { squares }\end{array}$ & Mean square & $\mathbf{F}$ & $\mathbf{P}$ \\
\hline Vegetation & 1 & 70.15 & 70.15 & 6.32 & 0.019 \\
\hline Surface type & 2 & $2,406.59$ & $1,203.30$ & 108.32 & 0.000 \\
\hline $\begin{array}{l}\text { Vegetation } x \\
\text { surface }\end{array}$ & 2 & 6.05 & 3.03 & 0.27 & 0.764 \\
\hline Error & 24 & 266.60 & 11.11 & & \\
\hline
\end{tabular}


Table 3-10. Sand and Gravel Mulches Analysis of Variance, September 1988 to May 1990.

\begin{tabular}{|c|c|r|r|r|r|}
\hline \multicolumn{7}{|c|}{ CUMULATIVE STORAGE CHANGE } \\
\hline Source & DF & $\begin{array}{c}\text { Sum of } \\
\text { squares }\end{array}$ & Mean square & F & P \\
\hline Vegetation & 1 & 152.16 & 152.16 & 10.54 & 0.003 \\
\hline Surface type & 2 & $5,068.78$ & $2,534.39$ & 175.51 & 0.000 \\
\hline $\begin{array}{l}\text { Vegetation } \\
\text { surface }\end{array}$ & 2 & 55.27 & 27.63 & 1.91 & 0.169 \\
\hline Error & 24 & 346.57 & 14.44 & & \\
\hline \multicolumn{1}{|c|}{ Source } & DF & $\begin{array}{c}\text { Sum of } \\
\text { squares }\end{array}$ & Mean square & F & P \\
\hline Vegetation & 1 & 160.48 & 160.48 & 12.07 & 0.002 \\
\hline Surface type & 2 & $5,216.13$ & 2.608 .06 & 196.07 & 0.000 \\
\hline $\begin{array}{l}\text { Vegetation } \\
\text { surface }\end{array}$ & 2 & 53.85 & 26.93 & 2.024 & 0.154 \\
\hline Error & 24 & 319.24 & 13.30 & & \\
\hline
\end{tabular}

Table 3-11. Sand and Gravel Mulches Analysis of Variance, September 1988 to October 1990.

\begin{tabular}{|l|c|r|r|r|r|}
\hline \multicolumn{7}{|c|}{ CUMULATIVE STORAGE CHANGE } \\
\hline Source & DF & $\begin{array}{c}\text { Sum of } \\
\text { squares }\end{array}$ & Mean square & F & P \\
\hline Vegetation & 1 & 210.86 & 210.86 & 9.79 & 0.005 \\
\hline Surface type & 2 & $5,083.63$ & $2,541.82$ & 118.04 & 0.000 \\
\hline $\begin{array}{l}\text { Vegetation } \\
\text { surface }\end{array}$ & 2 & 130.91 & 65.45 & 3.04 & 0.067 \\
\hline Error & 24 & 516.79 & 21.53 & & \\
\hline \multicolumn{1}{|c|}{ Source } & DF & $\begin{array}{c}\text { Sum of } \\
\text { squares }\end{array}$ & Mean square & F & P \\
\hline Vegetation & 1 & 248.08 & 248.08 & 12.19 & 0.002 \\
\hline Surface type & 2 & $5,358.06$ & 2.679 .03 & 131.63 & 0.000 \\
\hline $\begin{array}{l}\text { Vegetation } \\
\text { Euriace }\end{array}$ & 2 & 122.25 & 61.13 & 3.00 & 0.069 \\
\hline Error & 24 & 488.48 & 20.35 & & \\
\hline
\end{tabular}


Table 3-12. Sand and Gravel Mulches Analys is of Variance, September 1988 to March 1991.

\begin{tabular}{|c|c|c|c|c|c|}
\hline \multicolumn{6}{|c|}{ CUMULATIVE STORAGE CHANGE } \\
\hline Source & DF & $\begin{array}{l}\text { Sum of } \\
\text { squares }\end{array}$ & Mean square & $F$ & $\mathbf{P}$ \\
\hline Vegetation & 1 & 0.001 & 0.001 & 0.00 & 0.995 \\
\hline Surface type & 2 & $4,280.96$ & $2,140.43$ & 110.23 & 0.000 \\
\hline $\begin{array}{l}\text { Vegetation } x \\
\text { surface }\end{array}$ & 2 & 10.87 & 5.44 & 0.28 & 0.758 \\
\hline Error & 24 & 466.05 & 19.42 & & \\
\hline \multicolumn{6}{|c|}{ CUMULATIVE EVAPOTRANSPIRATION } \\
\hline Source & DF & $\begin{array}{l}\text { Sum of } \\
\text { squares }\end{array}$ & Mean square & $\bar{F}$ & $P$ \\
\hline Vegetation & 1 & 25.74 & 25.74 & 2.76 & 0.110 \\
\hline Surface type & 2 & $5,097.30$ & $2,548.65$ & 273.54 & 0.000 \\
\hline $\begin{array}{l}\text { Vegetation } x \\
\text { surface }\end{array}$ & 2 & 35.30 & 17.65 & 1.89 & 0.172 \\
\hline Error. & 24 & 223.62 & 9.32 & & \\
\hline
\end{tabular}

Table 3-13. Sand and Gravel Mulches Analysis of Variance, September 1988 to September 1991.

\begin{tabular}{|l|c|r|r|r|r|}
\hline \multicolumn{7}{|c|}{ CUMULATIVE STORAGE CHANGE } \\
\hline Source & DF & $\begin{array}{c}\text { Sum of } \\
\text { squares }\end{array}$ & Mean square & F & P \\
\hline Vegetation & 1 & 707.95 & 707.95 & 13.97 & 0.001 \\
\hline Surface type & 2 & $6,093.32$ & $3,046.66$ & 60.11 & 0.000 \\
\hline $\begin{array}{l}\text { Vegetation } \\
\text { surface }\end{array}$ & 2 & 116.78 & 58.39 & 1.15 & 0.333 \\
\hline Error & 24 & $1,216.46$ & 50.69 & & \\
\hline \multicolumn{1}{|c|}{ CUMULATIVE EVAPOTRANSPIRATION } & \\
\hline Source & DF & $\begin{array}{c}\text { Sum of } \\
\text { squares }\end{array}$ & Mean square & F & P \\
\hline Vegetation & 1 & $1,185.91$ & $1,185.91$ & 31.20 & 0.000 \\
\hline Surface type & 2 & $7,489.80$ & $3,744.90$ & 98.53 & 0.000 \\
\hline $\begin{array}{l}\text { Vegetation } \\
\text { surface }\end{array}$ & 2 & 71.14 & 35.57 & 0.936 & 0.406 \\
\hline Error & 24 & 912.15 & 38.01 & & \\
\hline
\end{tabular}


Table 3-14. Sand and Gravel Mulches Analysis of Variance, September 1988 to March 1992.

\begin{tabular}{|c|c|c|c|c|c|}
\hline \multicolumn{6}{|c|}{ CUMULATIVE STORAGE CHANGE } \\
\hline Source & DF & $\begin{array}{l}\text { Sum of } \\
\text { squares }\end{array}$ & Mean square & $\mathbf{F}$ & $\mathbf{P}$ \\
\hline Vegetation & 1 & 163.51 & 163.51 & 3.77 & 0.64 \\
\hline Surface type & 2 & $4,988.61$ & $2,494.31$ & 57.54 & 0.000 \\
\hline $\begin{array}{c}\text { Vegetation } x \\
\text { surface }\end{array}$ & 2 & 197.66 & 98.83 & 2.28 & 0.124 \\
\hline Error & 24 & $1,040.45$ & 43.35 & & \\
\hline \multicolumn{6}{|c|}{ CUMULATIVE EVAPOTRANSPIRATION } \\
\hline Source & DF & $\begin{array}{l}\text { Sum of } \\
\text { squares }\end{array}$ & Mean square & $\mathbf{F}$ & $P$ \\
\hline Vegetation & 1 & 521.25 & 521.25 & 25.46 & 0.000 \\
\hline Surface type & 2 & $6,738.58$ & $3,369.29$ & 164.55 & 0.000 \\
\hline $\begin{array}{l}\text { Vegetation } x \\
\text { surface }\end{array}$ & 2 & 82.60 & 41.30 & 2.02 & 0.155 \\
\hline Error & 24 & 491.43 & 20.48 & & \\
\hline
\end{tabular}


WHC-EP-0597

Figure 3-20. Sand and Gravel Mulches Storage Change Differences.

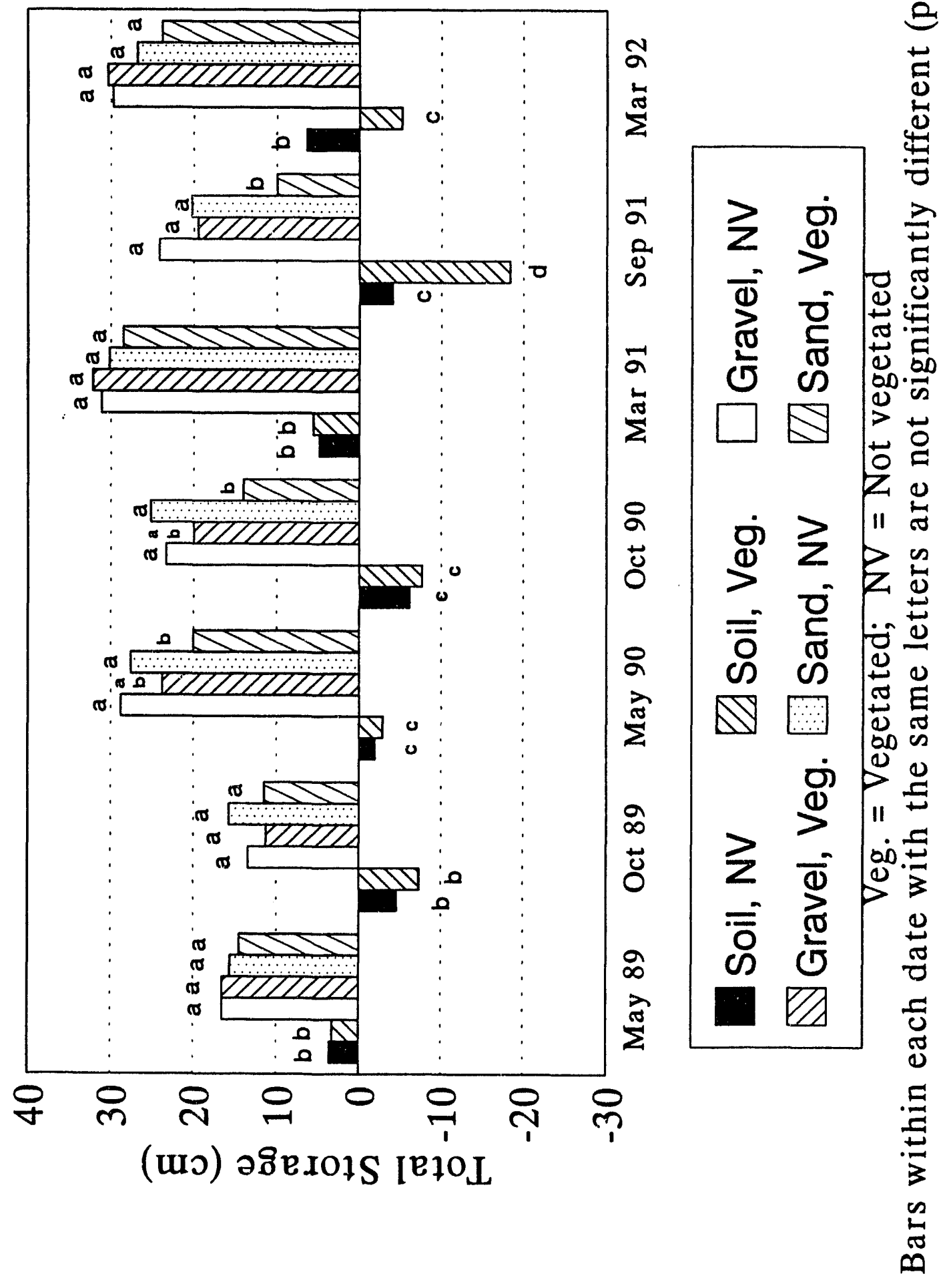


Figure 3-21. Sand and Grave? Mulches Total Evapotranspiration Differences.

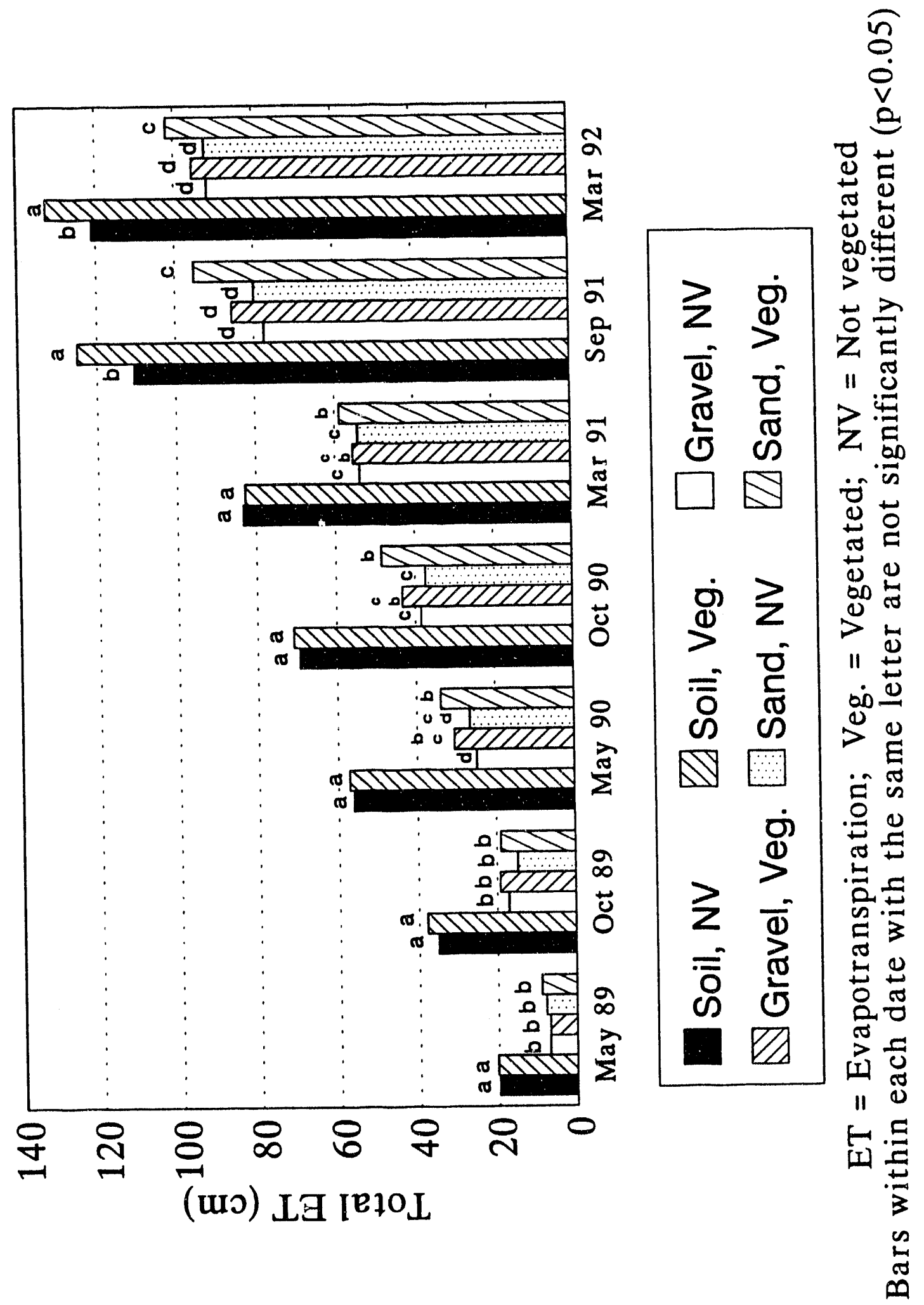




\subsection{CAPILLARY BREAK CONFIGURATION AND IMPERMEABLE LAYERS}

The presence of either the alternative, bimodal capillary break structure or an impermeable clay or grout layer has very little effect on the overall pattern of storage (Figure 3-22) or ET iFigure 3-23). The presence of vegetation does increase the amount of ET and decreases the amount of storage, but the subsurface treatments have very little effect.

The statistical analyses for the selected measurement dates for the capillary break treatments are provided in Tables 3-15 through 3-21, and the analyses for the subsurface, impermeable layers are presented in Tables 3-22 through 3-28. For the capiliary break treatments the control treatments are the irrigated, plain soil surface treatments, and for the subsurface impermeable layer treatments the control is the bimodal, nonvegetated treatment. Treatment means for all of these treatments are shown in Figures 3-24 (storage) and 3-25 (ET).

For the capillary break configurations the only significant effect was that of vegetation, and this was only true for the autumn measurement dates. On all three of the autumn measurement dates the amount of storage was lower and the amount of ET was higher for the vegetated treatments compared to the nonvegetated treatments. For all of the spring measurement dates, there were no significant differences between the vegetated and nonvegetated treatments. There were never any significant differences between the graded and bimodal treatments, and the interaction between vegetation and capillary break configuration was never significant.

On the first and on the last two analysis dates the lysimeters with a grout layer had significantly lower storage and higher ET than the clay layer or nonvegetated bimodal lysimeters. The differences at the first analysis date may result from differences in the time to equilibrium for the different treatments, while there seems to be no easy explanation for the differences observed on the last two analysis dates. This may be a statistical artifact in that the within-treatment variation for the three treatments in this analysis are the smallest of all 18 treatments. For instance, the standard deviation for the bimodal for March 1992, nonvegetated treatment is 1.235 , for the clay layer it is 0.743 , and for the grout layer it is 1.291 . All of the other treatments have standard deviations ranging from about 2.6 to 8.3. Therefore, the observed differences of about $4 \mathrm{~cm}$ for both ET and storage would not have been significant for other treatment combinations.

None of the lysimeters used in the tests of alternative capillary break configurations or subsurface impermeable barriers have produced any detectable amounts of drainage. 
Figure 3-22. Alternative Barrier Types Cumulative Storage Change.

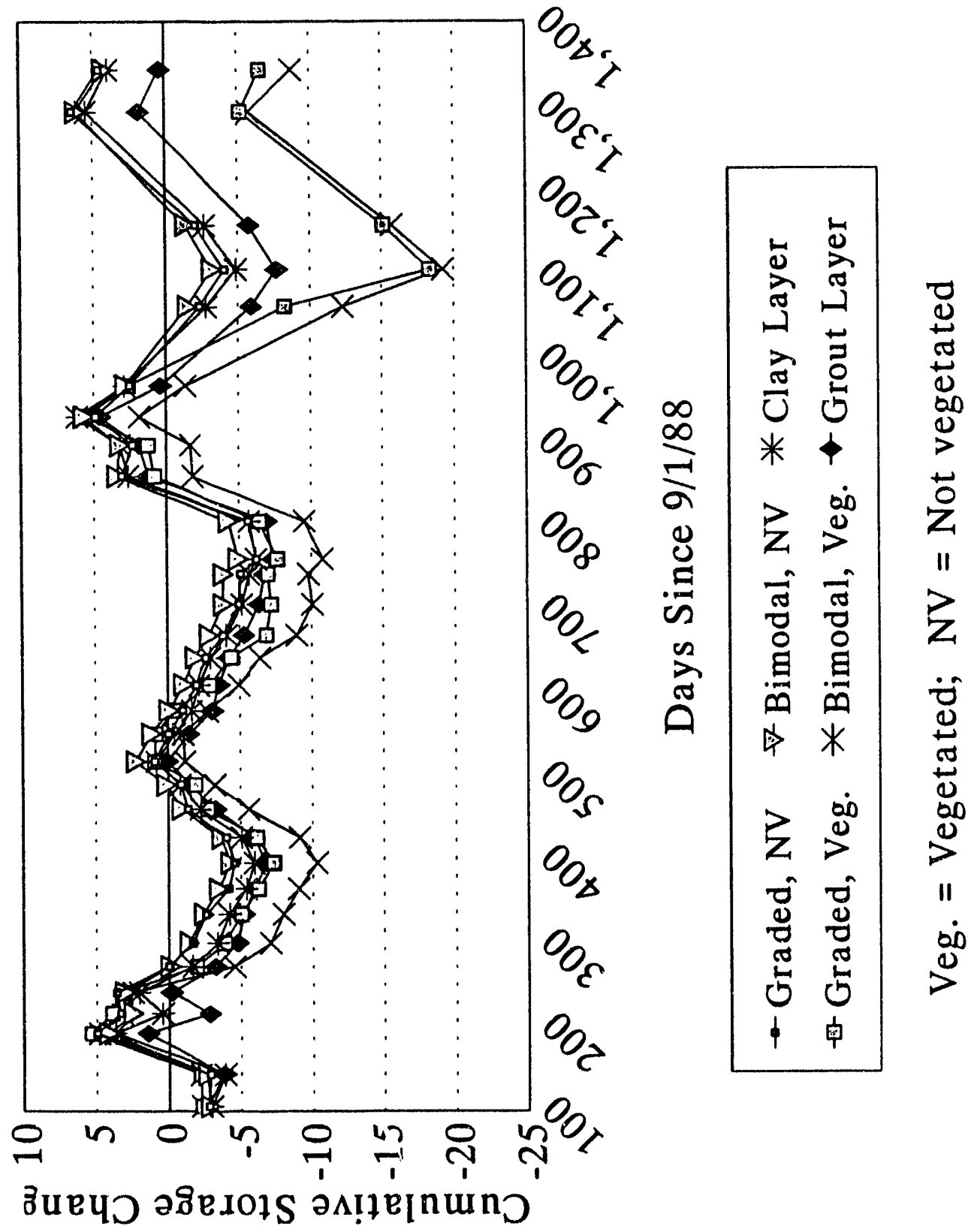




\section{WIIC-EP-0597}

Figure 3-23. Alternative Barrier Types Cumulative Evapotranspiration.

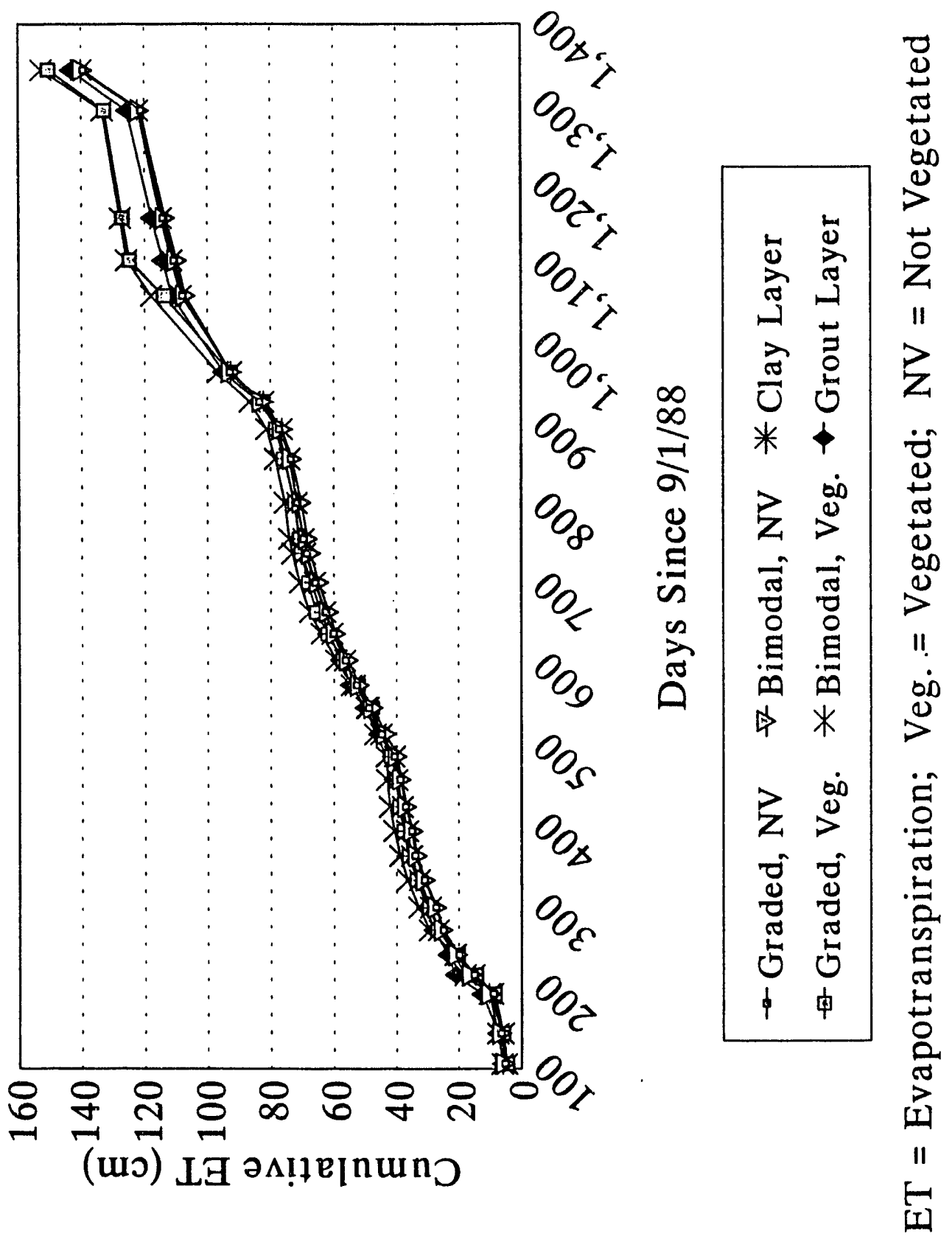


Table 3-15. Capillary Break Configuration Analysis of Variance, September 1988 to May 1989.

\begin{tabular}{|l|c|r|r|r|r|}
\hline \multicolumn{7}{|c|}{ CUMULATIVE STORAGE CHANGE } \\
\hline Source & DF & $\begin{array}{c}\text { Sum of } \\
\text { squares }\end{array}$ & Mean square & $F$ & $P$ \\
\hline Barrier type & 1 & 2.270 & 2.270 & 0.647 & 0.433 \\
\hline Vegetation & 1 & 1.091 & 1.091 & 0.311 & 0.585 \\
\hline $\begin{array}{c}\text { Bar type } x \\
\text { vegetation }\end{array}$ & 1 & 0.079 & 0.079 & 0.022 & 0.833 \\
\hline Error & 16 & 56.151 & 3.509 & & \\
\hline \multicolumn{1}{|c|}{ CUMULATIVE EVAPOTRANSPIRATION } \\
\hline Source & DF & $\begin{array}{c}\text { Sum of } \\
\text { squares }\end{array}$ & Mean square & $F$ & $P$ \\
\hline Barrier type & 1 & 2.273 & 2.273 & 0.649 & 0.432 \\
\hline Vegetation & 1 & 1.119 & 1.119 & 0.320 & 0.580 \\
\hline $\begin{array}{c}\text { Bar type } x \\
\text { vegetation }\end{array}$ & 1 & 0.078 & 0.078 & 0.022 & 0.884 \\
\hline Error & 16 & 56.006 & 3.500 & & \\
\hline
\end{tabular}

Table 3-16. Capillary Break Configuration Analysis of Variance, September 1988 to October 1989.

\begin{tabular}{|c|c|c|c|c|c|}
\hline \multicolumn{6}{|c|}{ CUMULATIVE STORAGE CHANGE } \\
\hline Source & DF & $\begin{array}{l}\text { Sum of } \\
\text { squares }\end{array}$ & Mean square & $\mathbf{F}$ & $\mathbf{P}$ \\
\hline Barrier type & 1 & 9.004 & 9.004 & 1.136 & 0.302 \\
\hline Vegetation & 1 & 95.741 & 95.741 & 12.075 & 0.003 \\
\hline $\begin{array}{l}\text { Bar type } x \\
\text { vegetation }\end{array}$ & 1 & 13.396 & 13.396 & 1.689 & 0.212 \\
\hline Error & 16 & 126.863 & 7.929 & & \\
\hline \multicolumn{6}{|c|}{ CUMULATIVE EVAPOTRANSPIRATION } \\
\hline Source & DF & $\begin{array}{l}\text { Sum of } \\
\text { squares }\end{array}$ & Mean square & $F$ & $P$ \\
\hline Barrier type & 1 & 9.011 & 9.011 & 1.137 & 0.302 \\
\hline Vegetation & 1 & 96.008 & 96.008 & 12.112 & 0.003 \\
\hline $\begin{array}{l}\text { Bar type } x \\
\text { vegetation }\end{array}$ & 1 & 13.382 & 13.382 & 1.688 & 0.212 \\
\hline Error & 16 & 126.828 & 7.927 & & \\
\hline
\end{tabular}


Table 3-17. Capillary Break Configuration Analysis of Variance, September 1988 to May 1990.

\begin{tabular}{|c|c|r|r|r|r|}
\hline \multicolumn{7}{|c|}{ CUMULATIVE STORAGE CHANGE } \\
\hline Source & DF & $\begin{array}{c}\text { Sum of } \\
\text { squares }\end{array}$ & Mean square & F & P \\
\hline Barrier type & 1 & 1.607 & 1.607 & 0.175 & 0.681 \\
\hline Vegetation & 1 & 29.026 & 29.026 & 3.165 & 0.094 \\
\hline $\begin{array}{c}\text { Bar type } x \\
\text { vegetation }\end{array}$ & 1 & 10.626 & 10.626 & 1.158 & 0.298 \\
\hline Error & 16 & 146.757 & 9.172 & & \\
\hline \multicolumn{7}{|c|}{ CUMULATIVE EVAPOTRANSPIRATION } \\
\hline Source & DF & $\begin{array}{c}\text { Sum of } \\
\text { squares }\end{array}$ & Mean square & $F$ & P \\
\hline Barrier type & 1 & 1.615 & 1.615 & 0.176 & 0.680 \\
\hline Vegetation & 1 & 29.149 & 29.149 & 3.177 & 0.094 \\
\hline $\begin{array}{c}\text { Bar type } x \\
\text { vegetation }\end{array}$ & 1 & 10.628 & 10.628 & 1.158 & 0.298 \\
\hline Error & 16 & 146.809 & 9.176 & & \\
\hline
\end{tabular}

Table 3-18. Capillary Break Configuration Analysis of Variance, September 1988 to October 1990.

\begin{tabular}{|c|c|r|r|r|r|}
\hline \multicolumn{7}{|c|}{ CUMULATIVE STORAGE CHANGE } \\
\hline Source & DF & $\begin{array}{c}\text { Sum of } \\
\text { squares }\end{array}$ & Mean square & $F$ & $P$ \\
\hline Barrier type & 1 & 4.315 & 4.315 & 0.594 & 0.452 \\
\hline Vegetation & 1 & 67.480 & 67.480 & 9.276 & 0.008 \\
\hline $\begin{array}{l}\text { Bar type } x \\
\text { vegetation }\end{array}$ & 1 & 24.013 & 24.013 & 3.297 & 0.088 \\
\hline Error & 16 & 116.400 & 7.275 & & \\
\hline \multicolumn{1}{|c|}{ CUMULATIVE EVAPOTRANSPIRATION } \\
\hline \multicolumn{1}{|c|}{ Source } & DF & $\begin{array}{c}\text { Sum of } \\
\text { squares }\end{array}$ & Mean square & $F$ & $P$ \\
\hline Barrier type & 1 & 4.329 & 4.329 & 0.594 & 0.452 \\
\hline Vegetation & 1 & 67.667 & 67.667 & 9.291 & 0.008 \\
\hline $\begin{array}{l}\text { Bar type } x \\
\text { vegetation }\end{array}$ & 1 & 24.013 & 24.013 & 3.297 & 0.088 \\
\hline Error & 16 & 116.530 & 7.283 & & \\
\hline
\end{tabular}


Table 3-19. Capillary Break Configuration Analysis of Variance, September 1988 to March 1991.

\begin{tabular}{|c|c|r|r|r|r|}
\hline \multicolumn{7}{|c|}{ CUMULATIVE STORAGE CHANGE } \\
\hline Source & DF & $\begin{array}{c}\text { Sum of } \\
\text { squares }\end{array}$ & Mean square & $F$ & $P$ \\
\hline Barrier type & 1 & 10.655 & 10.655 & 0.849 & 0.371 \\
\hline Vegetation & 1 & 12.738 & 12.738 & 1.015 & 0.329 \\
\hline $\begin{array}{c}\text { Bar type } x \\
\text { vegetation }\end{array}$ & 1 & 25.660 & 25.660 & 2.045 & 0.172 \\
\hline Error & 16 & 200.792 & 12.550 & & \\
\hline \multicolumn{7}{|c|}{ CUMULATIVE EVAPOTRANSPIRATION } & \\
\hline \multicolumn{1}{|c|}{ Source } & DF & $\begin{array}{c}\text { Sum of } \\
\text { squares }\end{array}$ & Mean square & $F$ & 0.370 \\
\hline Barrier type & 1 & 10.677 & 10.677 & 0.851 & 0.327 \\
\hline Vegetation & 1 & 12.820 & 12.820 & 1.022 & 0.172 \\
\hline $\begin{array}{c}\text { Bar type } x \\
\text { vegetation }\end{array}$ & 1 & 25.663 & 25.663 & 2.046 & \\
\hline Error & 16 & 200.700 & 12.544 & & \\
\hline
\end{tabular}

Table 3-20. Capillary Break Configuration Analysis of Variance, September 1988 to September 1991.

\begin{tabular}{|c|c|c|c|c|c|}
\hline \multicolumn{6}{|c|}{ CUMULATIVE STORAGE CHANGE } \\
\hline Source & DF & $\begin{array}{l}\text { Sum of } \\
\text { squares }\end{array}$ & Mean square & $\mathbf{F}$ & $\mathbf{P}$ \\
\hline Barrier type & 1 & 0.00 & 0.00 & 0.00 & 0.994 \\
\hline Vegetation & 1 & $1,150.05$ & $1,150.05$ & 159.84 & 0.000 \\
\hline $\begin{array}{l}\text { Bar type } x \\
\text { vegetation }\end{array}$ & 1 & 4.12 & 4.12 & 0.57 & 0.460 \\
\hline Error & 16 & 115.12 & 7.20 & & \\
\hline \multicolumn{6}{|c|}{ CUMULATIVE EVAPOTRANSPIRATION } \\
\hline Source & DF & $\begin{array}{l}\text { Sum of } \\
\text { squares }\end{array}$ & Mean square & $\mathbf{F}$ & $\mathbf{P}$ \\
\hline Barrier type & 1 & 0.001 & 0.001 & 0.00 & 0.993 \\
\hline Vegetation & 1 & $1,150.826$ & $1,150.826$ & 159.48 & 0.000 \\
\hline $\begin{array}{l}\text { Bar type } x \\
\text { vegetation }\end{array}$ & 1 & 4.119 & 4.119 & 0.57 & 0.461 \\
\hline Error & 16 & 115.455 & 7.126 & & \\
\hline
\end{tabular}


Table 3-21. Capillary Break Configuration Analysis of Variance, September 1988 to March 1992.

\begin{tabular}{|c|c|r|r|r|r|}
\hline \multicolumn{7}{|c|}{ CUMULATIVE STORAGE CHANGE } \\
\hline Source & DF & $\begin{array}{c}\text { Sum of } \\
\text { squares }\end{array}$ & Mean square & F & P \\
\hline Barrier type & 1 & 0.944 & 0.944 & 0.125 & 0.729 \\
\hline Vegetation & 1 & 692.705 & 692.705 & 91.519 & 0.000 \\
\hline $\begin{array}{c}\text { Bar type } x \\
\text { vegetation }\end{array}$ & 1 & 0.113 & 0.113 & 0.015 & 0.904 \\
\hline Error & 16 & 121.103 & 7.569 & & \\
\hline & \multicolumn{6}{|c|}{ CUMULATIVE EVAPOTRANSPIRATION } \\
\hline Source & DF & $\begin{array}{c}\text { Sum of } \\
\text { squares }\end{array}$ & Mean square & $F$ & $P$ \\
\hline Barrier type & 1 & 0.951 & 0.951 & 0.126 & 0.728 \\
\hline Vegetation & 1 & 693.305 & 693.305 & 91.553 & 0.000 \\
\hline $\begin{array}{l}\text { Bar type } x \\
\text { vegetation }\end{array}$ & 1 & 0.113 & 0.113 & 0.015 & 0.904 \\
\hline Error & 16 & 121.164 & 7.573 & & \\
\hline
\end{tabular}

Table 3-22. Alternative/Impermeable Barriers Analysis of Variance, September 1988 to May 1989.

\begin{tabular}{|l|c|r|r|r|r|}
\hline \multicolumn{1}{|c|}{ Source } & DF & $\begin{array}{c}\text { Sum of } \\
\text { squares }\end{array}$ & Mean square & $F$ & $P$ \\
\hline Sublayer & 2 & 27.120 & 13.560 & 14.595 & 0.001 \\
\hline Error & 12 & 11.149 & 0.929 & & \\
\hline \multicolumn{7}{|c|}{ CUMULATIVE EVAPOTRANSPIRATION } \\
\hline \multicolumn{1}{|c|}{ Source } & DF & $\begin{array}{c}\text { Sum of } \\
\text { squares }\end{array}$ & Mean square & F & $P$ \\
\hline Sublayer & 2 & 25.405 & 12.702 & 13.452 & 0.001 \\
\hline Error & 12 & 11.331 & 0.944 & & \\
\hline
\end{tabular}


Table 3-23. Alternative/Impermeable Barriers Analysis of Variance, September 1988 to October 1989.

\begin{tabular}{|l|c|r|r|r|r|}
\hline \multicolumn{1}{|c|}{ Source } & DF & $\begin{array}{c}\text { Sum of } \\
\text { squares }\end{array}$ & Mean square & F & P \\
\hline Sublayer & 2 & 16.106 & 8.053 & 3.845 & 0.051 \\
\hline Error & 12 & 25.130 & 2.094 & & \\
\hline \multicolumn{7}{|c|}{ CUMULATIVE EVAPOTRANSPIRATION } \\
\hline Source & DF & $\begin{array}{c}\text { Sum of } \\
\text { squares }\end{array}$ & Mean square & F & P \\
\hline Sublayer & 2 & 15.000 & 7.500 & 3.662 & 0.057 \\
\hline Error & 12 & 24.575 & 2048 & & \\
\hline
\end{tabular}

Table 3-24. Alternative/Impermeable Barriers Analysis of Variance, September 1988 to May 1990.

\begin{tabular}{|c|c|c|c|c|c|}
\hline \multicolumn{7}{|c|}{ CUMULATIVE STORAGE CHANGE } \\
\hline Source & DF & $\begin{array}{c}\text { Sum of } \\
\text { squares }\end{array}$ & Mean square & $F$ & $P$ \\
\hline Sublayer & 2 & 15.533 & 7.767 & 3.481 & 0.067 \\
\hline Error & 12 & 27.268 & 2.272 & & \\
\hline \multicolumn{7}{|c|}{ CUMULATIVE EVAPOTRANSPIRATION } \\
\hline Source & DF & $\begin{array}{c}\text { Sum of } \\
\text { squares }\end{array}$ & Mean square & $F$ & $P$ \\
\hline Sublayer & 2 & 14.297 & 7.148 & 3.113 & 0.081 \\
\hline Error & 12 & 27.559 & 2.297 & & \\
\hline
\end{tabular}


Table 3-25. Alternative/Impermeable Barriers Analys is of Variance, September 1988 to October 1990.

\begin{tabular}{|l|c|r|r|r|r|}
\hline \multicolumn{1}{|c|}{ Source } & DF & $\begin{array}{c}\text { Sum of } \\
\text { squares }\end{array}$ & Mean square & F & $P$ \\
\hline Sublayer & 2 & 14.828 & 7.414 & 3.306 & 0.072 \\
\hline Error & 12 & 26.908 & 2.242 & & \\
\hline \multicolumn{7}{|c|}{ CUMULATIVE EVAPOTRANSPIRATION } \\
\hline Source & DF & $\begin{array}{c}\text { Sum of } \\
\text { squares }\end{array}$ & Mean square & F & $P$ \\
\hline Sublayer & 2 & 13.687 & 6.843 & 3.054 & 0.085 \\
\hline Error & 12 & 26.893 & 2.241 & & \\
\hline
\end{tabular}

Table 3-26. Alternative/Impermeable Barriers Analysis of Variance, September 1988 to March 1991.

\begin{tabular}{|l|c|r|r|r|r|}
\hline \multicolumn{1}{|c|}{ CUMULATIVE STORAGE CHANGE } \\
\hline Source & DF & $\begin{array}{c}\text { Sum of } \\
\text { squares }\end{array}$ & Mean square & $F$ & $P$ \\
\hline Sublayer & 2 & 6.229 & 3.150 & 1.071 & 0.373 \\
\hline \multicolumn{7}{|c|}{ Crror } & 12 & 35.279 & 2.940 & & \\
\hline Source & DF & $\begin{array}{c}\text { Sum of } \\
\text { squares }\end{array}$ & Mean square & F & $P$ \\
\hline Sublayer & 2 & 5.396 & 2.698 & 0.873 & 0.443 \\
\hline Error & 12 & 37.103 & 3.092 & & \\
\hline
\end{tabular}


Table 3-27. Alternative/Impermeable Barriers Analys is of Variance, September 1988 to September 1991.

\begin{tabular}{|l|c|r|r|r|r|}
\hline \multicolumn{1}{|c|}{ Source } & DF & $\begin{array}{c}\text { Sum of } \\
\text { squares }\end{array}$ & Mean square & F & $P$ \\
\hline Sublayer & 2 & 51.707 & 25.854 & 14.450 & 0.001 \\
\hline Error & 12 & 21.470 & 1.789 & & \\
\hline \multicolumn{7}{|c|}{ CUMULATIVE EVAPOTRANSPIRATION } \\
\hline Source & DF & $\begin{array}{c}\text { Sum of } \\
\text { squares }\end{array}$ & Mean square & F & $P$ \\
\hline Sublayer & 2 & 49.317 & 24.659 & 13.937 & 0.001 \\
\hline Error & 12 & 21.232 & 1.769 & & \\
\hline
\end{tabular}

Table 3-28. Alternative/Impermeable Barriers Analysis of Variance, September 1988 to March 1992.

\begin{tabular}{|l|c|r|r|r|r|}
\hline \multicolumn{1}{|c|}{ CUMULATIVE STORAGE CHANGE } \\
\hline Source & DF & $\begin{array}{c}\text { Sum of } \\
\text { squares }\end{array}$ & Mean square & F & P \\
\hline Eublayer & 2 & 54.192 & 27.096 & 21.713 & 0.000 \\
\hline \multicolumn{7}{|c|}{ Error } & 12 & 14.975 & 1.248 & & \\
\hline Source & DF & $\begin{array}{c}\text { Sum of } \\
\text { squares }\end{array}$ & Mean square & F & P \\
\hline Error & 2 & 51.516 & 25.758 & 19.844 & 0.000 \\
\hline
\end{tabular}


WHC-EP-0597

Figure 3-24. Alternative Barrier Configurations Storage Change Differences.

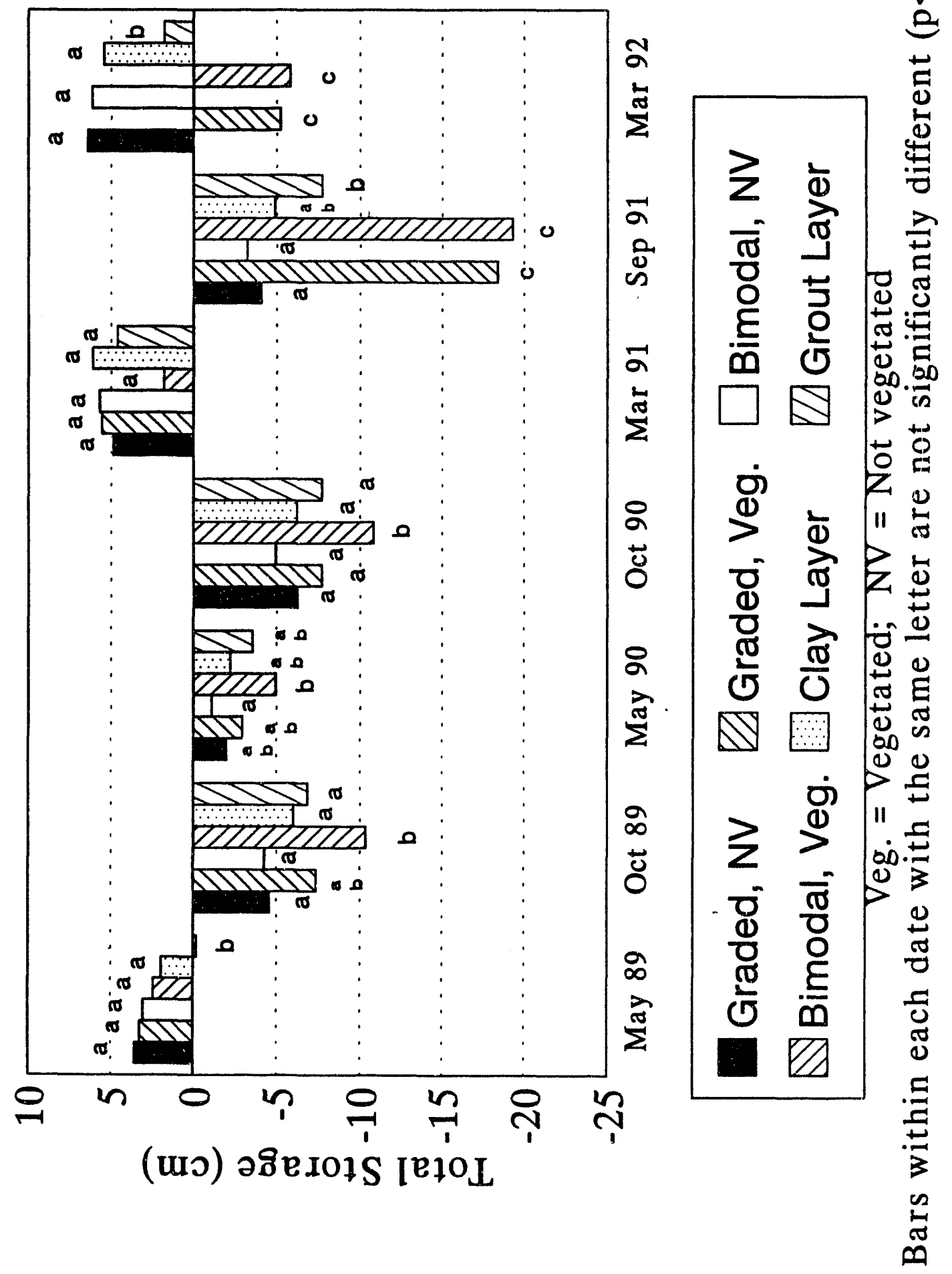


Figure 3-25. Alternative Barrier Configurations Total Evapotranspiration Differences.

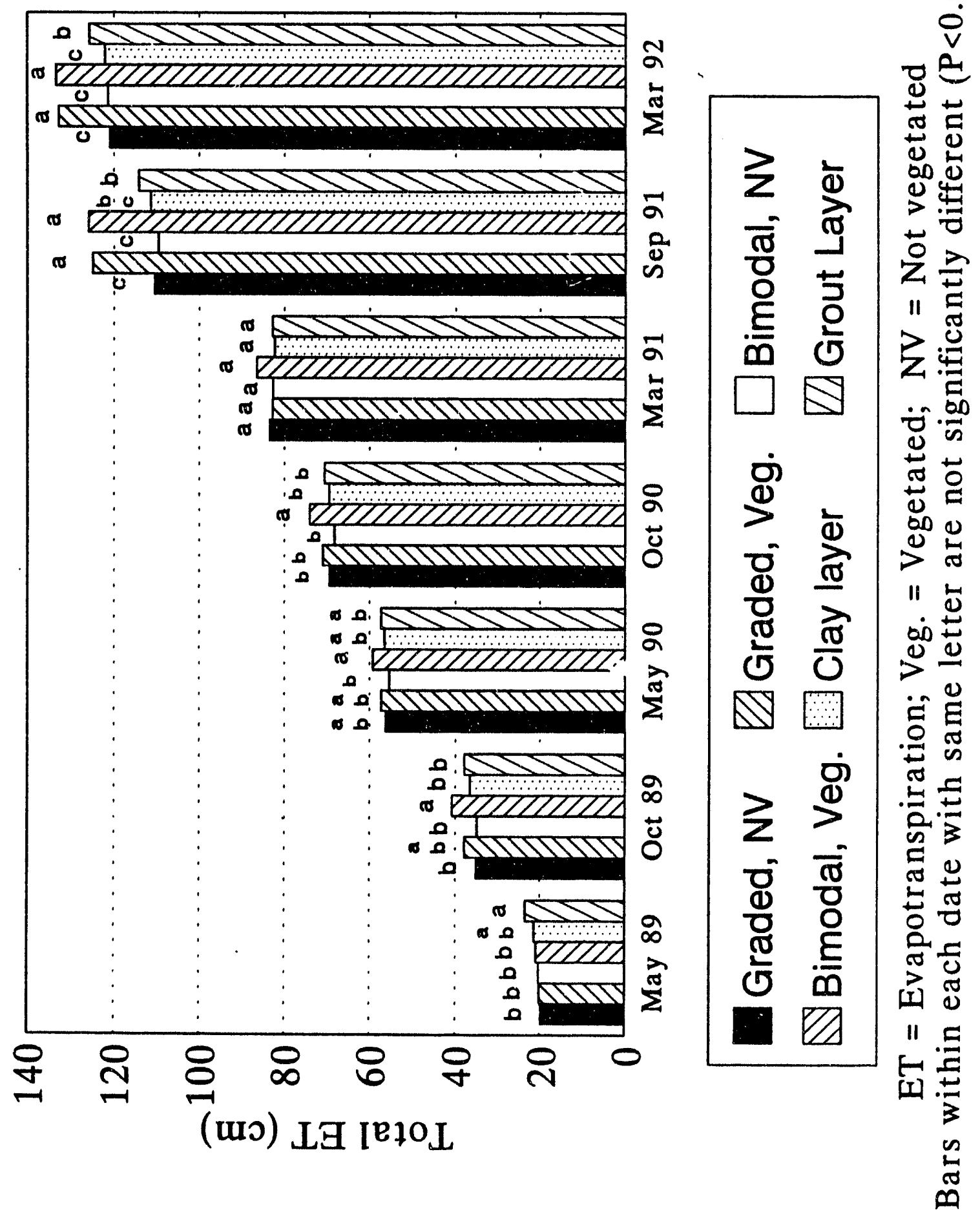




\subsection{SUMMARY AND CONCLUSIONS}

Drainage has not occurred in any of the lysimeters with soil or gravel admix surfaces; thus, the total amount of water input (ambient precipitation and supplemental irrigation) has been effectively partitioned into ET and storage. For the soil and gravel admix lysimeters, the amount of ET exceeded the amount of water input resulting in a net decrease in lysimeter water storage, except when supplemental irrigation was applied during the wettest periods of the year. At these times there was a very slight increase in water storage. The presence of a layer of gravel mulch or sand on the surface of the lysimeter greatly increases the amount of water storage and decreases the amount of ET compared to lysimeters with a plain soil or gravel admix surface. This is especially true for the sand and gravel mulch lysimeters that received supplemental irrigation. The nonirrigated, nonvegetated gravel mulch

lysimeters showed a steady increase in water storage during the last 3 years of observation, suggesting that ET from these lysimeters has been consistently less than precipitation. This suggests that, even under present climatic conditions, the potential for infiltration through the protective barrier is high if a gravel mulch surface is allowed to develop. The effects of a gravel mulch surface appear to be strongly offset by the presence of vegetation, at least under current ambient precipitation conditions.

The various subsurface treatments (bimodal capillary and graded capillary breaks, clay, and grout layers) had no effect on the overall soil water balance. None of the lysimeters in these tests has produced drainage, and the ET and water storage patterns are very similar.

Vegetative growth has not been directly measured on the lysimeters during these experiments, but the relative quantity of plant material was visually observed to be greater in 1991 and 1992 than in either of the previous 2 years. Indirect evidence for this is the increase in the amplitude of the seasonal fluctuations in water storage over the last 500 days of the experiments. Even with the increased amount of vegetation during the last 2 years, there appeared to be less plant material per unit area than in the surrounding, undisturbed shrub steppe. Thus the vegetation treatments are approximating a lower limit of plant productivity, which suggests that the measured amounts of ET may be less than the potential ET that may occur on a full-size protective barrier. Also, cheatgrass communities are relatively shallow rooted and have been reported to use less water than a sagebrushbunchgrass community occupying similar sites (cline et al. 1977). The protective barriers will probably be seeded with perennial bunchgrasses, which will be simulated in the vegetated lysimeters at STLF beginning in FY 1993. 
WHC-EP-0597

This page intentionally left blank. 


\subsection{REFERENCES}

Cline, J. F., D. W. Uresk, and W. H. Rickard, 1977, "Comparison of Soil Water Used by a Sagebrush-Bunchgrass and a Cheatgrass Community, "Journal of Range Management, 30:199-201.

Fayer, M. J., 1990, Test Plan for Hydrologic Modeling of Protective Barriers, PNL-7152, Pacific Northwest Laboratory, Richland, Washington.

Fayer, M. J., W. Conerbe, P. R. Heller, and G. W. Gee, 1985, Model Assessment of Protective Barrier Designs, PNL-5604, Pacific Northwest Laboratory, Richland, Washington.

Freeman, H. D. and G. W. Gee, 1989, Hanford Protective Barriers Program: Status of Asphalt Barrier Studies - FY 1989, PNL-7153, Pacific Northwest Laboratory, Richland, Washington.

Freeman, H. D., G. W. Gee, and J. F. Relyea, 1989, Field Study Plan for Alternate Barriers, PNL-6840, Pacific Northwest Laboratory, Richland, Washington.

Kirkham, R. R., G. W. Gee, and J. L. Downs, 1987, Field Lysimeter Test Facility for Protective Barriers: Experimental Plan, PNL-6351, Pacific Northwest Laboratory, Richland, Washington.

Ligotke, M. W., 1989, Surface Stability Test Plan for Protective Barriers, PNL-6722, Pacific Northwest Laboratory, Richland, Washington.

Ligotke, M. W. and D. C. Klopfer, 1990, Soil Erosion Rates from Mixed Soil and Gravel Surfaces in a Wind Tunnel, PNL-7435, Pacific Northwest Laboratory, Richland, Washington.

Link, S. O., and W. J. Waugh, 1989, Evapotranspiration Studies for Protective Barriers: Experimental Plans, PNL-6899, Pacific Northwest Laboratory, Richland, Washington.

Link, S. O., M. F. Thiede, R. D. Evans, J. L. Downs, and W. J. Waugh, 1990, Evapotranspiration Studies for Protective Barriers: FY 1989 Status Report, PNL-6985, Pacific Northwest Laboratory, Richland, Washington.

Relyea, J. F., M. R. Sackschewsky, and W. J. Waugh, 1990, Small-Tube Lysimeter Facility Status Report for Fiscal Year 1989, WHC-EP-0297, Westinghouse Hanford Company, Richland, Washington.

Sackschewsky, M. R., C. J. Kemp, L. L. Cadwell, M. E. Theide, and W. J. Waugh, 1991, Status Report for the Small-tube Lysimeter Facility Fiscal Year 1990, WHC-EP-0381, Westinghouse Hanford Company, Richland, Washington. 
Snedecor, G. W. and W. G. Cochran, 1980, Statistical Methods, seventh edition, The Iowa State University Press, Ames, Iowa.

DOE, 1987, Disposal of Hanford Defense High-Level, Transuranic, and Tank Wastes, DOE/EIS-0113, U.S. Department of Energy, Washington, D.C.

Waugh, W. J. and S. 0. Link, 1987, Barrier Erosion Control Test Plan: GravelMulch, Vegetation, and Soil-Water Interactions, WHC-EP-0067, Westinghouse Hanford Company, Richland, Washington.

Waugh, W. J., 1989, Gravel Admix, Vegetation, and Soil-Water Interactions in Protective Barriers: Experimental Design, Construction, and Initial Conditions, PNL-6616, Pacific Northwest Laboratory, Richland, Washington. 
WHC-EP-0597

\section{DISTRIBUTION}

\section{OFFSITE}

4

2

1

2
DOE/Office of Scientific and Technical Information

Los Alamos National Laboratory

P. 0. Box 1663

Los Alamos, NM 87545

ATTN: T. E. Hakonson

J. W. Nyhan

W. J. Waugh

Chem Nuclear Geotech

P.0. Box 14000

Grand Junction, CO 81502

EBASCO

1201 Jadwin

Richland, WA 99352

ATTN: W. Riggsbee

R. L. Treat

\section{ONSITE}

DOE Field Office, Richland

G. J. Bracken

J. J. Broderick

P. K. Clür

R. D. Freeburg

R. E. Gerton

A5-19

R. E. Gerton

J. D. Goodenough

A. C. Harris

R. D. Izatt

P. M. Pak

R. K. Stewart

D. E. Trader

A3-42

A5-19

A5-19

DOE-RL Reading Room 1

K8-50

$\mathrm{H} 2-53$

EPA - Hanford Project Office

P. R. Beaver

D. A. Faulk

L. E. Gadbois

B5-01

P. S. Innis

B5-01

D. R. Sherwood 
Distribution (cont.)

M. R. Adams

H6-01

W. C. Alaconis

H6-28

J. W. Cammann

H4-14

R. A. Carlson

H6-03

C. E. Hodge

A5-56

K. N. Jordan

H6-28

C. J. Kemp

H4-14

M. K. Korenko

B3-08

D. S. Landeen

H4-14

M. J. Lauterbach

H6-01

H. E. McGuire

B3-63

D. R. Myers

H4-14

K. L. Petersen

H4-14

S. J. Phillips

H4-14

R. W. Powell

M. R. Sackschewsky (11)

H4-14

W. A. Skelly

J. C. Sonnichsen

H4-14

H6-03

N. R. Wing

H4-14

H4-14

T. M. Wintczak

H6-27

D. D. (Don) Wodrich

B1-59.

R. D. Wojtasek

H6-27

D. E. Wood

$\mathrm{HO}-33$

J. G. Wool ard

Publishing Services (3)

H6-05

Environmental Data Management Center (2)

Pacific Northwest Laboratory

L. L. Cadwell

M. D. Campbel1

J. L. Downs

M. J. Fayer

M. G. Foley

H. D. Freeman

G. W. Gee (2)

M. J. Graham

P. C. Hays

C. T. Kincaid

R. R. Kirkham

G. V. Last

M. H. Ligotke

S. 0. Link

M. L. Rockhold

L. E. Rogers

R. A. Romine

M. A. Simmons

R. L. Skaggs

S. C. Slate
P7-54

K6-77

P7-54

K6-77

K6-84

P8-38

K6-77

K6-78

K6-86

K6-77

K6-77

K6-96

P7-54

P7-54

K6-77

P7-54

P8-38

P7-54

K6-77

K1-19 
WHC-EP-0597

\section{DISTRIBUTION (cont.)}

M. E. Thiede

K6-13

W. H. Walters

K6-06

Technical Report Files

P8-55

Distr-3 

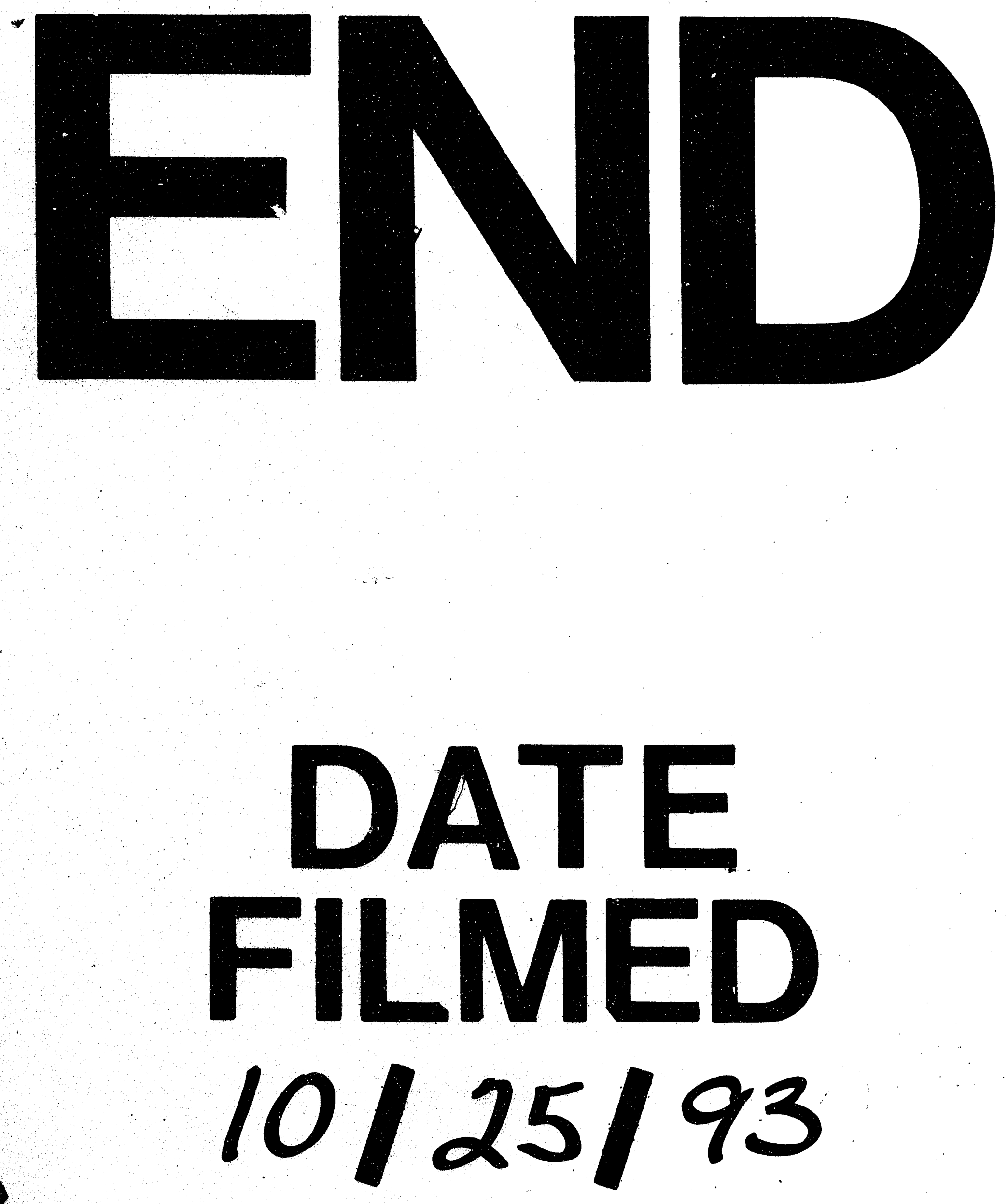

1 
